U.S. Department of the Interior

U.S. Geological Survey

In cooperation with the U.S. Army Corps Of Engineers,

Louisville District

\title{
HYDROGEOLOGY AND SIMULATION \\ OF GROUND-WATER FLOW IN THE \\ OHIO RIVER ALLUVIAL AQUIFER \\ NEAR WEST POINT, KENTUCKY
}

Water-Resources Investigations Report 99-4265

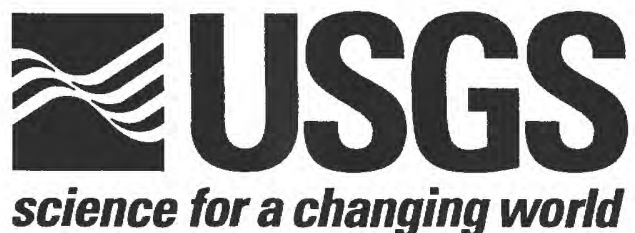


U.S. Department of the Interior

U.S. Geological Survey

\section{HYDROGEOLOGY AND SIMULATION OF GROUND-WATER FLOW IN THE OHIO RIVER ALLUVIAL AQUIFER NEAR WEST POINT, KENTUCKY}

By M.D. Unthank and H.L. Nelson Jr.

Water-Resources Investigations Report 99-4265

In cooperation with the U.S. Army Corps Of Engineers, Louisville District 


\section{U.S. DEPARTMENT OF THE INTERIOR \\ BRUCE BABBITT, Secretary}

\section{U.S. GEOLOGICAL SURVEY}

Charles G. Groat, Director

Any use of trade, product, or firm names in this publication is for descriptive purposes only and does not imply endorsement by the U.S. Government.

For additional information write to:

District Chief, Kentucky District

U.S. Geological Survey

Water Resources Division

9818 Bluegrass Parkway

Louisville, KY 40299-1906
Copies of this report can be purchased from:

U.S. Geological Survey

Branch of Information Services

Box 25286

Denver, CO 80225-0286 


\section{CONTENTS}

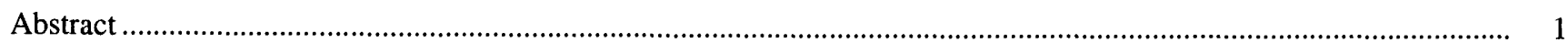

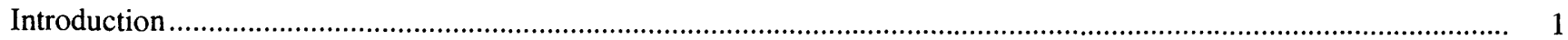

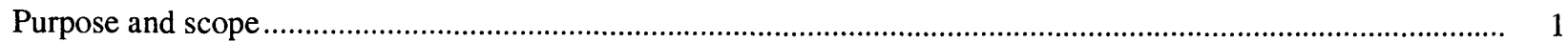

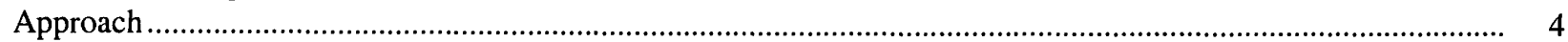

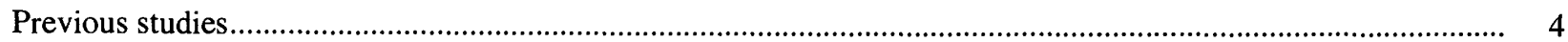

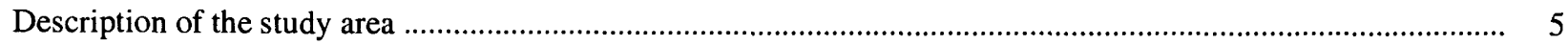

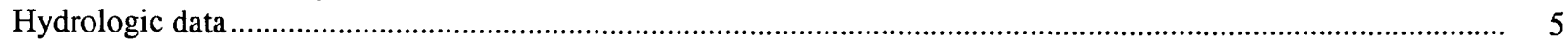

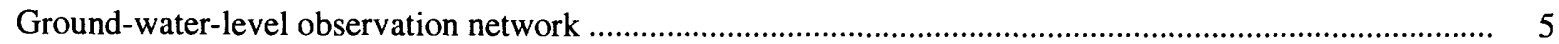

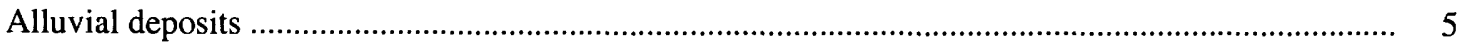

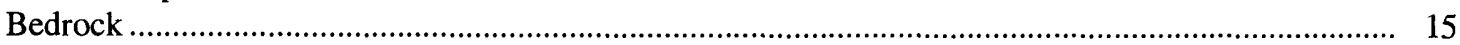

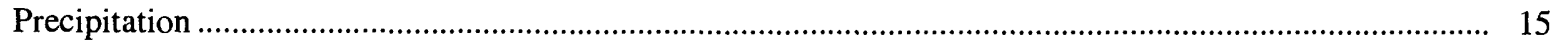

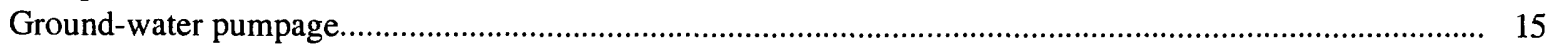

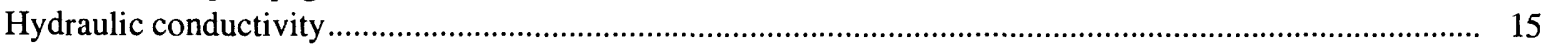

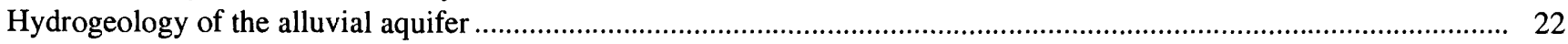

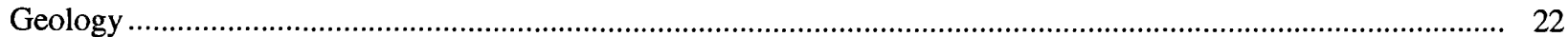

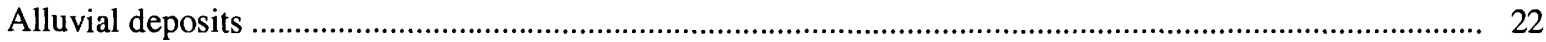

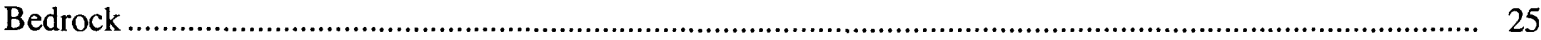

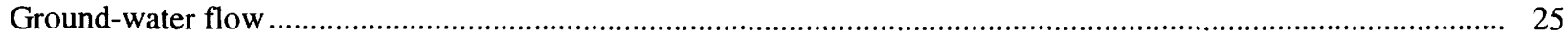

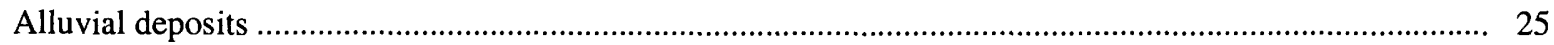

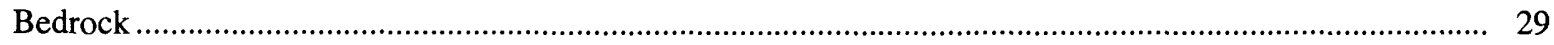

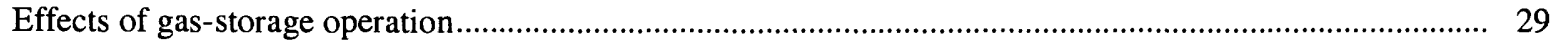

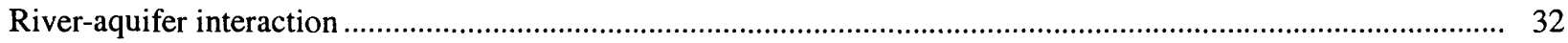

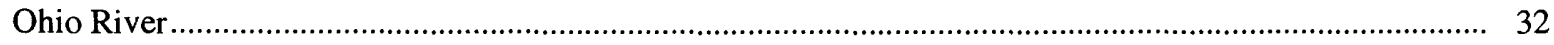

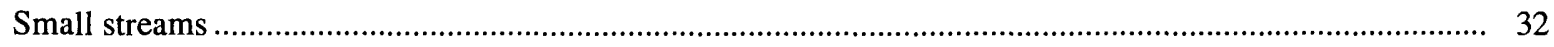

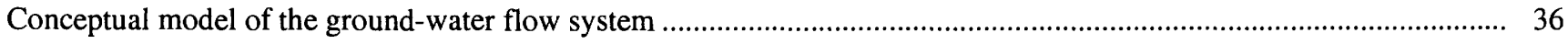

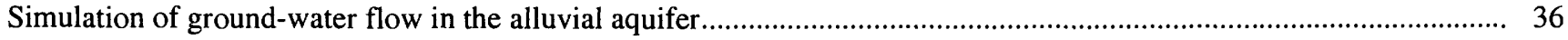

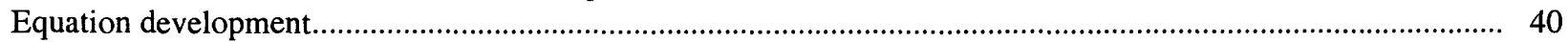

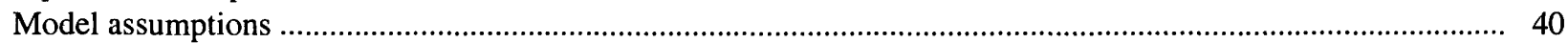

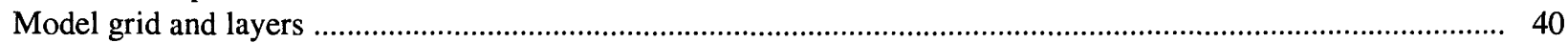

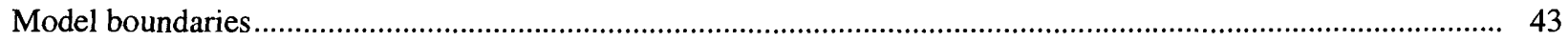

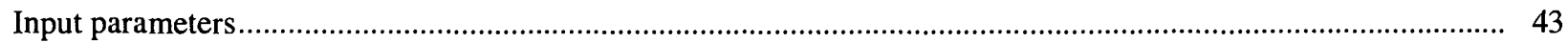

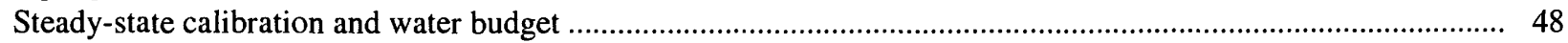

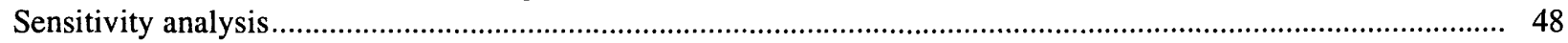

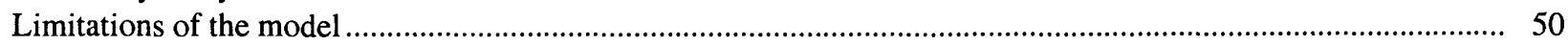

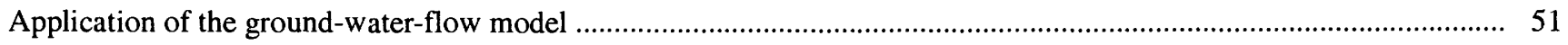

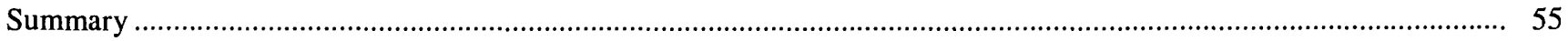

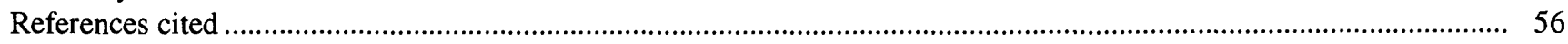

\section{FIGURES}

1-2. Maps showing:

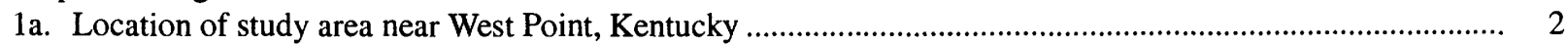

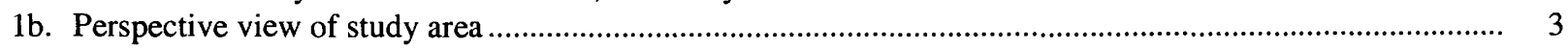

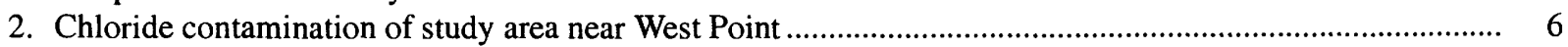

3-6. Maps showing water levels in selected wells of the alluvial aquifer for:

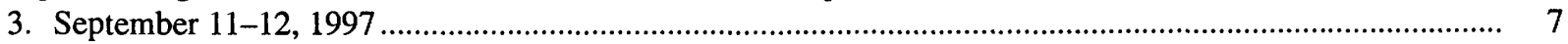

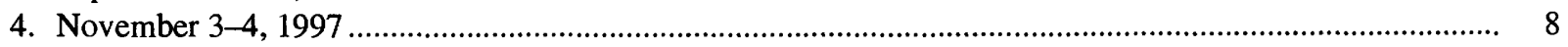

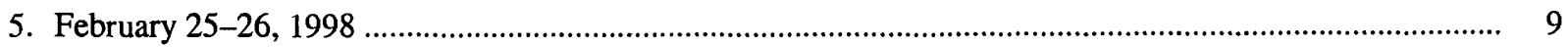

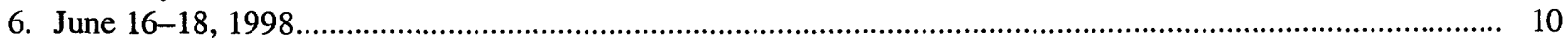


7-9. Hydrographs showing:

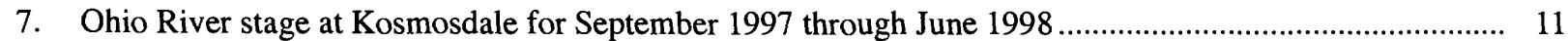

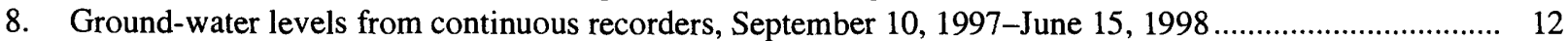

9. Simultaneous peaks in ground-water levels indicated at recorders 6,7 , and 8, June 1-15, 1998............... 16

10. Map showing location of oil-and-gas wells in the study area .............................................................. 17

11-13. Hydrographs showing:

11. Ground-water levels from recorder 9, April 25, 1998_January 31, 1999.......................................... 19

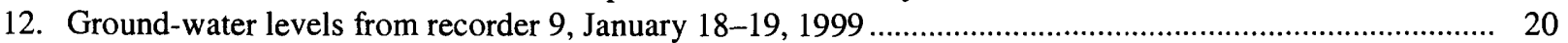

13. Ground-water levels from recorders 4 and 9, April 25, 1998-January 31, 1999 ............................... 21

14. Map showing location of public water-supply wells in the study area ....................................................... 23

15. Map showing location of slug tests and calculated hydraulic conductivities..................................................... 24

16. Stratigraphy of major geologic units of the West Point area, north-central Kentucky....................................... 25

17. Map showing generalized surficial geology of the study area near West Point, Kentucky ............................... 26

18. Map showing elevations of the bottom of the fine-grained deposits (clay cap) and bedrock surface ................. 27

19-21. Graphs showing:

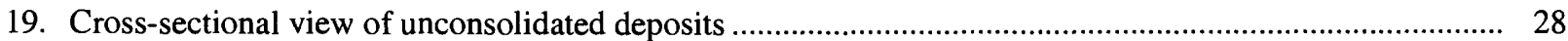

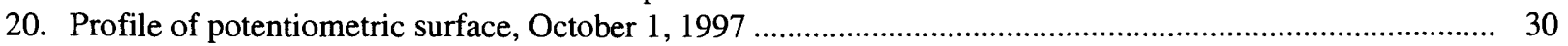

21. Profile of potentiometric surface, April 21, 1998 .......................................................................... 31

22. Map showing location of seismic-reflection survey traverses and survey results ........................................... 33

23a. Hydrograph showing response of ground-water levels to January 13,1988 , floodpulse on the Ohio River........ 34

23b. Hydrograph showing response of ground-water levels to March 25, 1988, floodpulse on the Ohio River.......... 35

24a. Map showing location of gaging sites for seepage run \#1, September 18-20, 1996 ................................... 37

24b. Map showing location of gaging sites for seepage run \#2, July 18, 1997............................................... 38

25. Block diagram showing layers simulated in model of the Ohio River alluvial aquifer ..................................... 41

26-34. Maps showing:

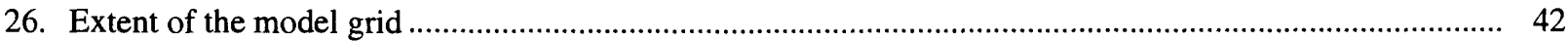

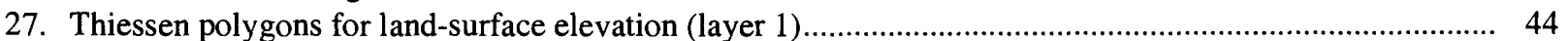

28. Thiessen polygons for elevation of fine-grained/coarse-grained deposits interface (layer 2).................... 45

29. Thiessen polygons for bedrock elevations (bottom of layer 2) .......................................................... 46

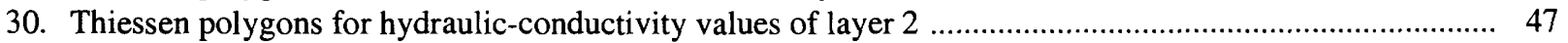

31. Observed versus modeled water levels for steady-state simulation .......................................................49

32. Contributing areas to discharge boundaries................................................................................. 52

33. Contributing area and time-of-travel estimates for a Fort Knox public water-supply well screened in the unconsolidated deposits .............................................................................................. 53

34. Flow paths and time-of-travel estimates from particle-tracking application of flow from an imaginary abandoned oil-and-gas well

\section{TABLES}

1. Status of abandoned oil-and-gas wells in the West Point area ................................................................. 18

2. Monthly precipitation totals at Louisville, Kentucky, September 1996-August 1998 …................................ 22

3. Pumpage from public water-supply wells, West Point, Kentucky, November 1997 ....................................... 22

4. Seepage run results for Abrahams Run, Tioga Creek, and their tributaries..................................................... 39

5. Results of sensitivity analyses of the calibrated flow model of the Ohio River alluvial aquifer near West Point, Kentucky 


\section{CONVERSION FACTORS AND VERTICAL DATUM}

\begin{tabular}{rll}
\hline Multiply & \multicolumn{1}{c}{ By } & To obtain \\
\hline inch (in.) & 2.54 & centimeter \\
pound per square inch $\left({\left.\mathrm{lb} / \mathrm{in}^{2}\right)}^{2}\right.$ & 703.1 & kilogram per square meter \\
foot (ft) & 0.3048 & meter \\
square foot $\left(\mathrm{ft}^{2}\right)$ & 0.09290 & square meter \\
cubic foot $\left(\mathrm{ft}^{3}\right)$ & 0.02832 & cubic meter \\
mile $(\mathrm{mi})$ & 1.609 & cubic meter per second \\
cubic foot per second $\left(\mathrm{ft}^{3} / \mathrm{s}\right)$ & 0.02832 & kilometer \\
square mile $\left(\mathrm{mi}^{2}\right)$ & 2.590 & square kilometer \\
foot per day $(\mathrm{ft} / \mathrm{d})$ & 0.3048 & meter per day \\
million gallons per day $(\mathrm{Mgal} / \mathrm{d})$ & 0.04381 & cubic meter per second \\
\hline
\end{tabular}

Sea level: In this report, "sea level" refers to the National Geodetic Vertical Datum of 1929 (NGVD of 1929)—a geodetic datum derived from a general adjustment of the first-order level nets of both the United States and Canada, formerly called Sea Level Datum of 1929.

Altitude, as used in this report, refers to distance above or below sea level.

Concentrations of chemical constituents in water are given in milligrams per liter. 


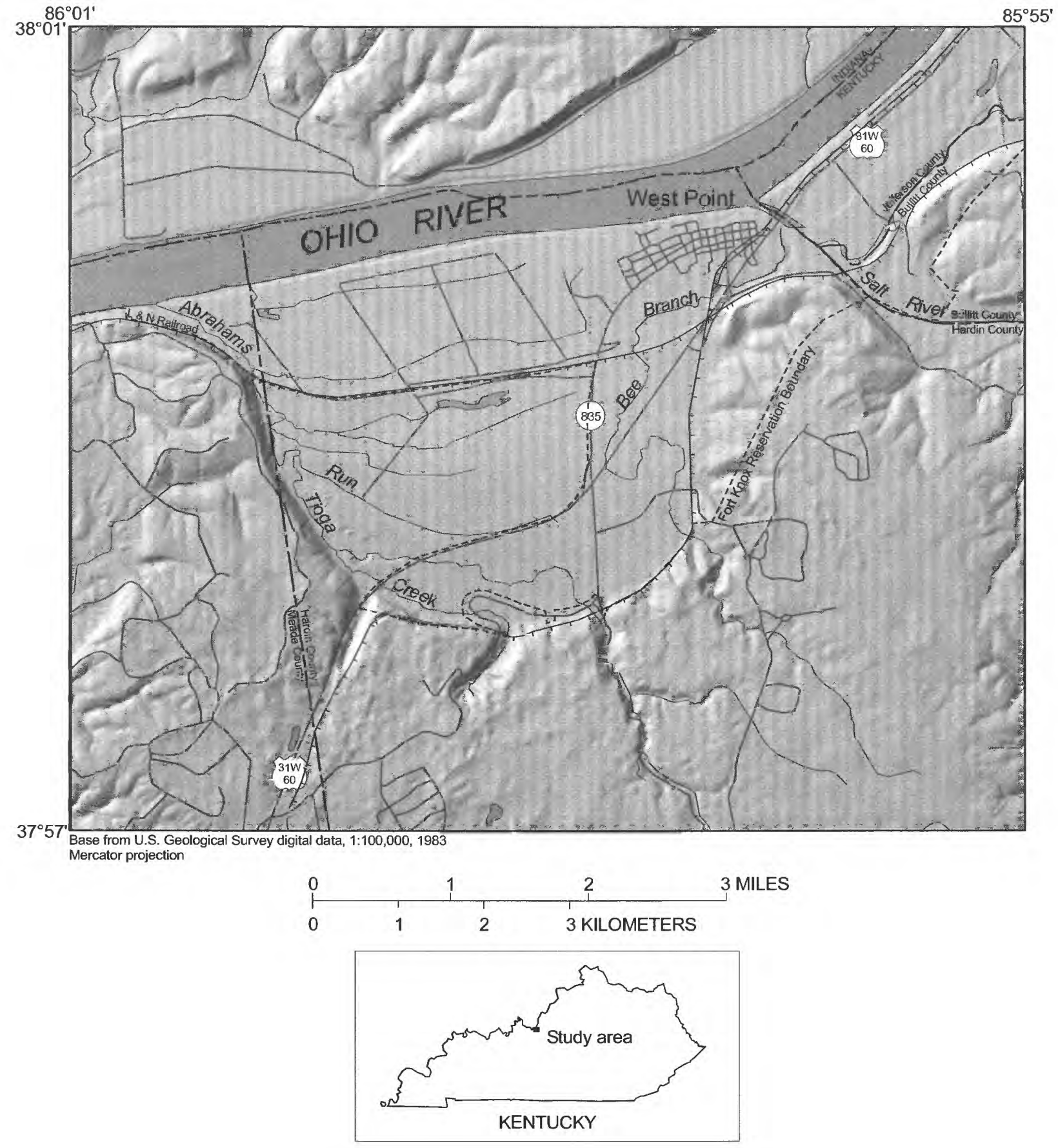

Figure 1a. Location of study area near West Point, Kentucky. 


\title{
HYDROGEOLOGY AND SIMULATION OF GROUND- WATER FLOW IN THE OHIO RIVER ALLUVIAL AQUIFER NEAR WEST POINT, KENTUCKY
}

\author{
By M.D. Unthank and H.L. Nelson Jr.
}

\section{Abstract}

The alluvial aquifer near West Point, Kentucky, lies in a cut-off meander of the Ohio River. The valley was eroded by glacial meltwater that was later partially filled with outwash sand and gravel deposits. The general flow direction of the ground water in the alluvial deposits is from the adjacent bedrock valley wall toward the Ohio River and ground-water withdrawal wells. Groundwater-level and Ohio River stage data indicate the alluvial aquifer was at or near steady-state conditions from September to December 1997 for a period of 3 months.

A three-dimensional, steady-state groundwater-flow model, employing the MODFLOW code, was developed to determine the contributing areas to and discharge boundaries for the Ohio River alluvial aquifer near West Point and the surrounding area. Ground water enters the modeled area by flow from the bedrock valley walls, infiltration from precipitation, and induced infiltration of water from the Ohio River. Ground water exits the modeled area primarily through pumped wells and discharge to the Ohio River.

Output from the MODFLOW simulation was used in the particle-tracking program MODPATH to delineate recharge and discharge boundaries of the flow system, contributing areas for withdrawal wells, and time-of-travel estimates through the flow system. Particle traces and timeof-travel estimates from confirmed locations of abandoned oil-and-gas exploratory wells were used to illustrate practical applications of the model for wellhead-protection concerns.

\section{INTRODUCTION}

The Ohio River alluvial aquifer at West Point, Ky., is an important water resource supplying drinking water for the city of West Point, Fort Knox, and Hardin County Water District No. 1. The supply wells for these three systems comprise one of the largest well fields in Kentucky, serving as the principal source of drinking water for over 50,000 people (Lyverse and Unthank, 1988).

Regional water managers and environmental coordinators need data and tools to understand and plan for current and future effects on the water resources of this area to ensure proper water use and environmental planning by all ground-water users. This is especially important in the West Point area because the aquifer is of limited areal extent. The area also contains a number of potential threats to the quality of the ground water, including leachate from the Distler Brickyard Superfund site and the leakage of saline water from several abandoned deep oil-and-gas wells.

In 1996, the U.S. Geological Survey (USGS), in cooperation with the U.S. Army Installation at Fort Knox, Ky., and the U.S. Army Corps of Engineers, Louisville District, began an investigation to characterize the hydrogeology of the Ohio River alluvial aquifer at West Point (fig. 1a and 1b) and to construct a numerical ground-water-flow model to aid in the management of the area's water resources. Numerical simulation of the ground-water-flow system provides a means to compile pertinent data, formulate and test conceptual models of the system, and incorporate these data and conceptualizations into a regionally consistent tool that can be used as the basis for water-use and environmental-planning decisions.

\section{Purpose and Scope}

This report describes the results of an investigation conducted during 1996-99 to refine the understanding 


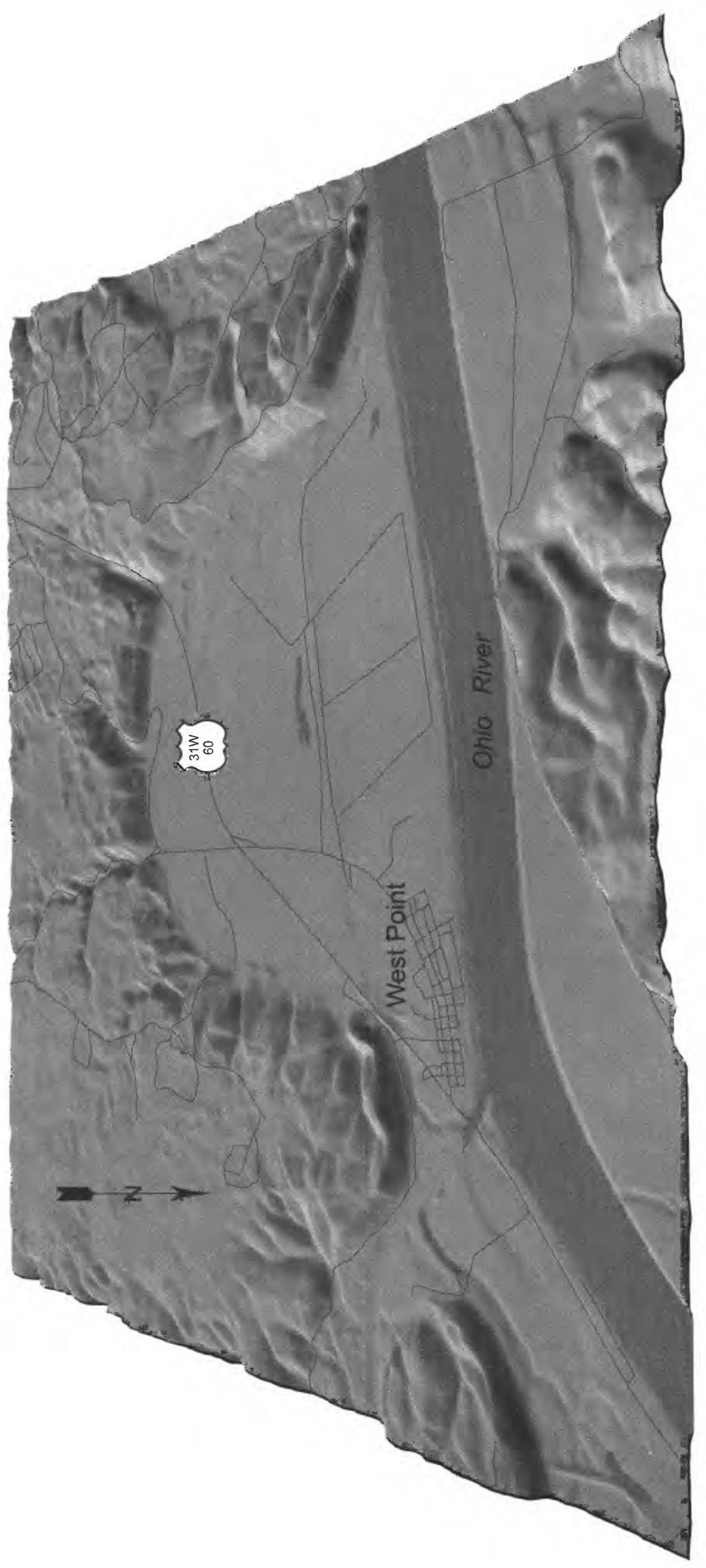

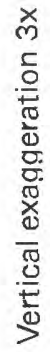

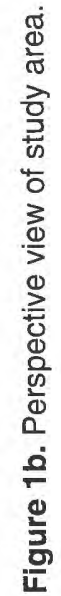


of the hydrogeology of the alluvial aquifer near West Point, Ky., and to characterize the ground-water-flow system. The hydrologic significance of geologic units in the study area is briefly discussed using the results of previous investigations, available and gathered hydrologic and lithologic data, and observations of water levels. A conceptualization of the ground-water-flow system is presented and a three-dimensional, steadystate, finite-difference ground-water-flow model is described. The study area is limited to the alluvial aquifer adjacent to the Ohio River in Hardin and Meade Counties, Ky. (fig. 1a and 1b).

\section{Approach}

The evaluation of the hydrogeology and groundwater flow in the Ohio River alluvial aquifer near West Point consisted of a review of published geologic and hydrologic literature, an inventory and measurement of ground-water levels in wells throughout the study area, a compilation of ground-water pumpage data, and aquifer tests to determine hydraulic conductivities. Finally, a hydrogeologic model of the ground-water-flow system was conceptualized and tested using a numerical ground-water-flow model.

Information collected during literature and file reviews provided a starting point for a field inventory of wells in the study area; a total of 35 wells were inventoried. Thirty of the wells were incorporated into a network of observation wells used to monitor changes in the water table. A drilling program was designed on the basis of the information collected by the observationwell network. Gaps in lithologic data and water-level control points existed in parts of the study area; therefore, an additional five monitoring wells were installed as part of this investigation. Depth-to-bedrock, lithology, and water-level data were gathered at these sites and incorporated into the data-collection activities for the study area. To keep the data and information collected for this investigation organized, a computerbased data-storage-and-retrieval system was designed using a geographic information system (GIS).

Additional field activities included quarterly waterlevel measurements, beginning in September 1996, and continuous water-level recordings at selected wells. Plots of the water levels were produced for selected time periods; eight of the water-level monitoring wells were equipped with continuous-recording pressure transducers to document trends in the water level. Depth to water and water temperature was measured at 30 minute intervals. Trends in the continuous water-level hydrographs showed the system to be at relative steady state during fall 1997.

Numerous field activities were conducted to further enhance the understanding of the ground-waterflow system and to provide needed data and information for the simulation. A series of seismic-reflection surveys (Brabets, 1995; Haeni, 1986) were conducted in the Ohio River to characterize the lithology of the riverbed and riverbank area. Slug tests were done on 12 monitoring wells to determine areal distributions of horizontal hydraulic conductivities. Slug tests are a means to determine the hydraulic conductivity of a deposit using a single monitoring well. For this investigation, an instantaneous change in the water level of the monitoring well was produced by suddenly removing a solid cylinder of known volume. The recovery of the water level with time was recorded and the data interpreted using the Hvorslev method (1951) to calculate a hydraulic conductivity. Finally, seepage runs were conducted in the study area to determine if surface streams were hydraulically connected to the ground-water-flow system. The seepage runs were made during fall 1996 and summer 1997. Seepage runs are a series of surfacewater discharge measurements made systematically to determine if the stream is receiving water from, discharging water to, or isolated from the ground-water flow system.

A steady-state, numerical model of flow in the alluvial aquifer (MODFLOW) was calibrated to groundwater levels from November 1997. Results from the calibrated ground-water-flow model were applied to an advective-flow particle-tracking program (MODPATH) to delineate ground-water flow paths, contributing areas to supply wells, and time-of-travel of water through the aquifer.

\section{Previous Studies}

Previous reports pertaining to the alluvial aquifer near West Point have been part of larger investigations of the alluvial deposits along the entire course of the Ohio River. Walker (1957) describes the geologic history of the Ohio River Valley; Gallaher and Price (1966) characterized the hydrologic system, and described the availability and development of ground-water supplies of the alluvial deposits. Brown and Lambert (1963) describe the availability of ground water in a multi- 
county study, which includes Hardin and Meade Counties and the West Point area. Information from these and other sources provided average hydrologic characteristics for the alluvial aquifer but did not identify local variability in the study area. More detailed information (depth to bedrock, geologic sections, and well logs) is contained in a USGS Hydrologic Investigations Atlas for the West Point area (Gallaher, 1964).

Lyverse and Unthank (1988) determined the extent and sources of high concentrations of chloride in the ground water in the study area. High concentrations of chloride had resulted in the abandonment of several public water-supply wells in the West Point area. During their investigation, Lyverse and Unthank collected water samples in which chloride concentrations were as high as 11,000 milligrams per liter. A summary of the chloride measurements is presented in figure 2. Electromagnetic surveys indicated and test drilling confirmed the presence of high concentrations of chloride in the alluvial aquifer near abandoned oil-and-gas exploration and production wells. The investigation concluded the potential for chloride contamination of additional wells existed in the study area; this potential was related to the proximity of the water wells to improperly abandoned oil-and-gas wells and to gradients in the water table created by drawdowns associated with pumped wells.

\section{Description of the Study Area}

The study area is in north-central Kentucky and is limited to $22.4 \mathrm{mi}^{2}$ of the Ohio River alluvial aquifer in a cut-off meander near West Point, Ky. (fig. 1a and 1b). Drainage is generally from east to west in intermittent streams that drain toward the Ohio River. The study area includes well fields for West Point, Hardin County Water District No. 1, and the U.S. Army Installation at Fort Knox.

The most prominent physical features of the study area are the rounded hills that range in altitude from about $400 \mathrm{ft}$ at the Ohio River to $450 \mathrm{ft}$ near Tioga Creek. The area is divided by the Louisville and Nashville Railroad track, which, for the most part, separates privately owned lands to the north of the tracks from the Fort Knox Military Reservation to the south. Privately owned land outside the boundaries of Fort Knox is sparsely populated with single-family farms that produce corn, hay, livestock, and dairy products. The military reservation in the study area is virtually uninhabited.

\section{Hydrologic Data}

A variety of new hydrologic and geologic data were collected as part of this investigation. A groundwater-level observation network of 35 wells was monitored during the period September 1996-August 1998. Monthly precipitation totals during the same period were recorded from the National Weather Service station in Louisville. Ground-water-pumpage records for the three public water-supply systems withdrawing ground water in the study area were collected and reviewed. A number of field tests were conducted on selected wells to calculate hydraulic conductivity and transmissivity values for the alluvial deposits.

\section{Ground-Water-Level Observation Network}

A total of 35 ground-water-level observation wells were monitored as part of this investigation. The network included abandoned domestic-supply wells, observation and test wells near public-water-supply wells, and a set of newly installed observation wells. Continuous water-level recording devices (pressure transducers) were installed on eight alluvial aquifer wells to document trends in ground-water levels and the aquifer's response to stresses such as pumpage, precipitation, and high Ohio River stage. Also, one continuous-recording device was installed on an abandoned oiland-gas exploratory well to monitor water-level changes in the bedrock beneath the alluvium.

\section{Alluvial Deposits}

Synoptic ground-water-level measurements were made six times during the course of the investigation in the observation wells finished in the alluvial deposits. Ground-water-level data for September and November 1997, and February and June 1998 synoptic measurements are presented in figures $3-6$. Figure 7 shows a hydrograph of the stage of the Ohio River during these four synoptic measurements. The measurements from the November 1997 synoptic were the target levels for the model calibration.

Eight of the observation wells completed in the alluvial deposits were equipped with continuousrecording devices (pressure transducers). The pressure transducers were set to record a pressure reading, which is converted to a water-level measurement, and water temperature on a 30-minute interval. Water-level hydrographs for the eight continuous recorders are presented in figure 8. 

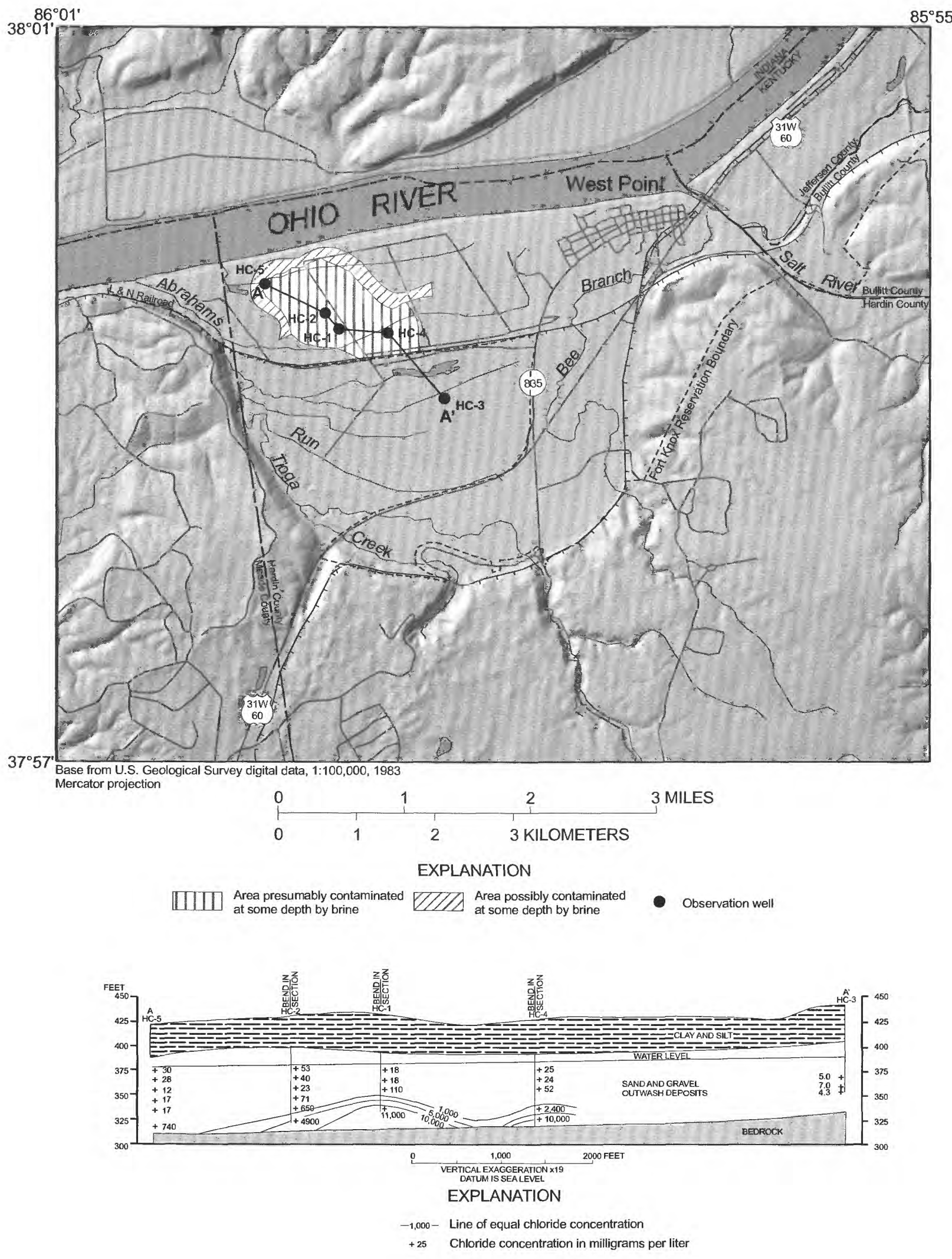

Figure 2. Chloride contamination of study area near West Point (modified from Lyverse and Unthank, 1988). 


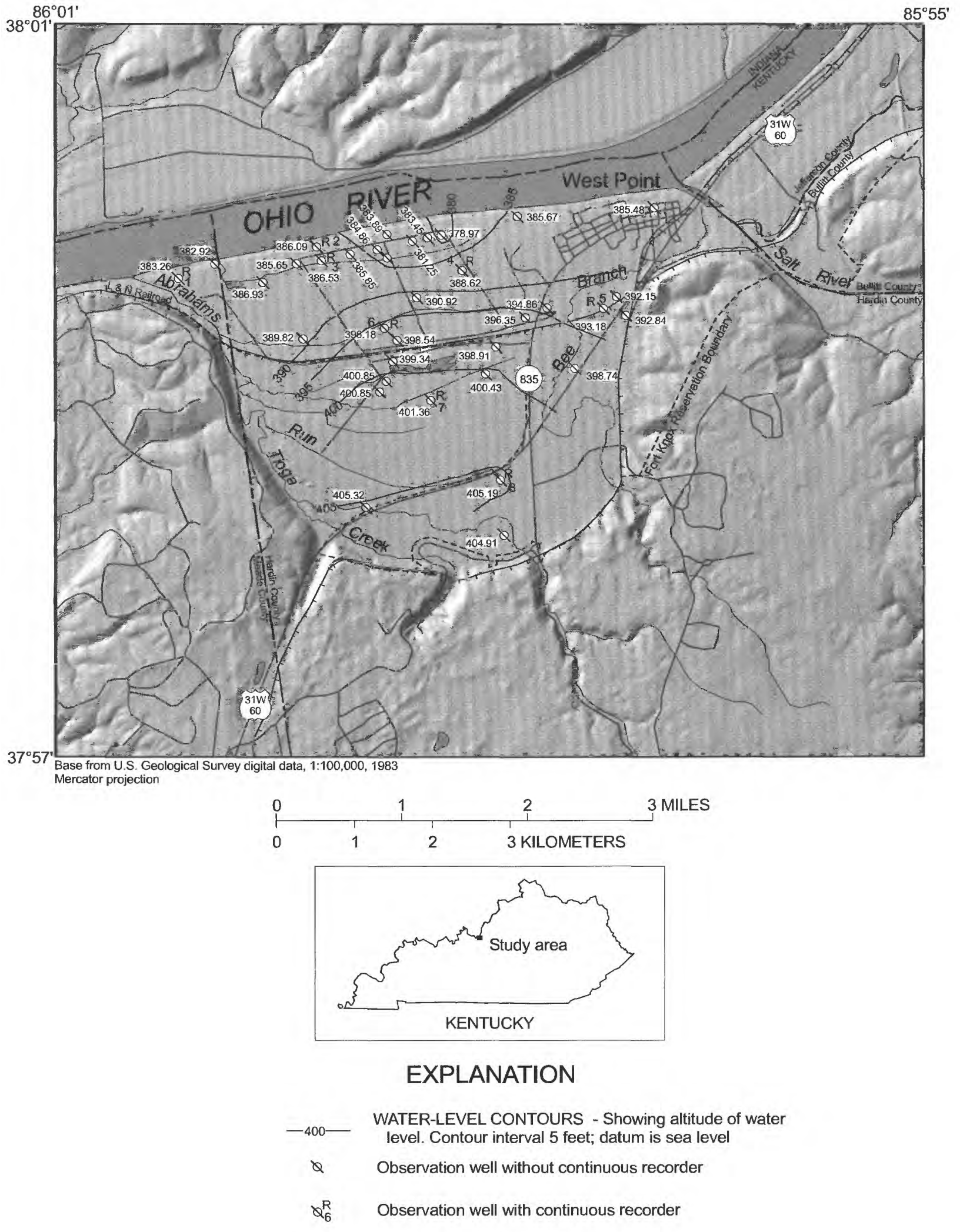

Figure 3. Water levels in selected wells of the alluvial aquifer, September 11-12, 1997. 


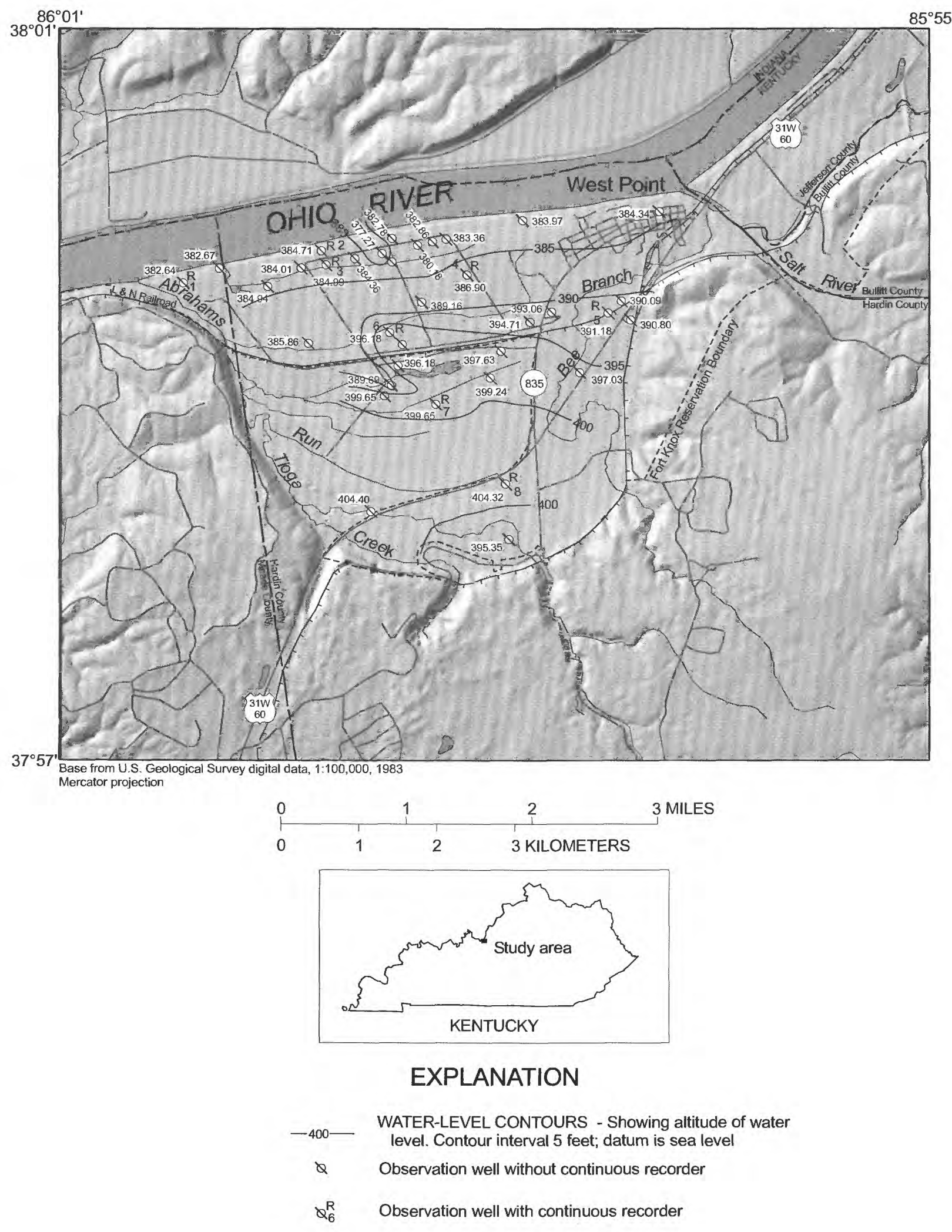

Figure 4. Water levels in selected wells of the alluvial aquifer, November 3-4, 1997. 


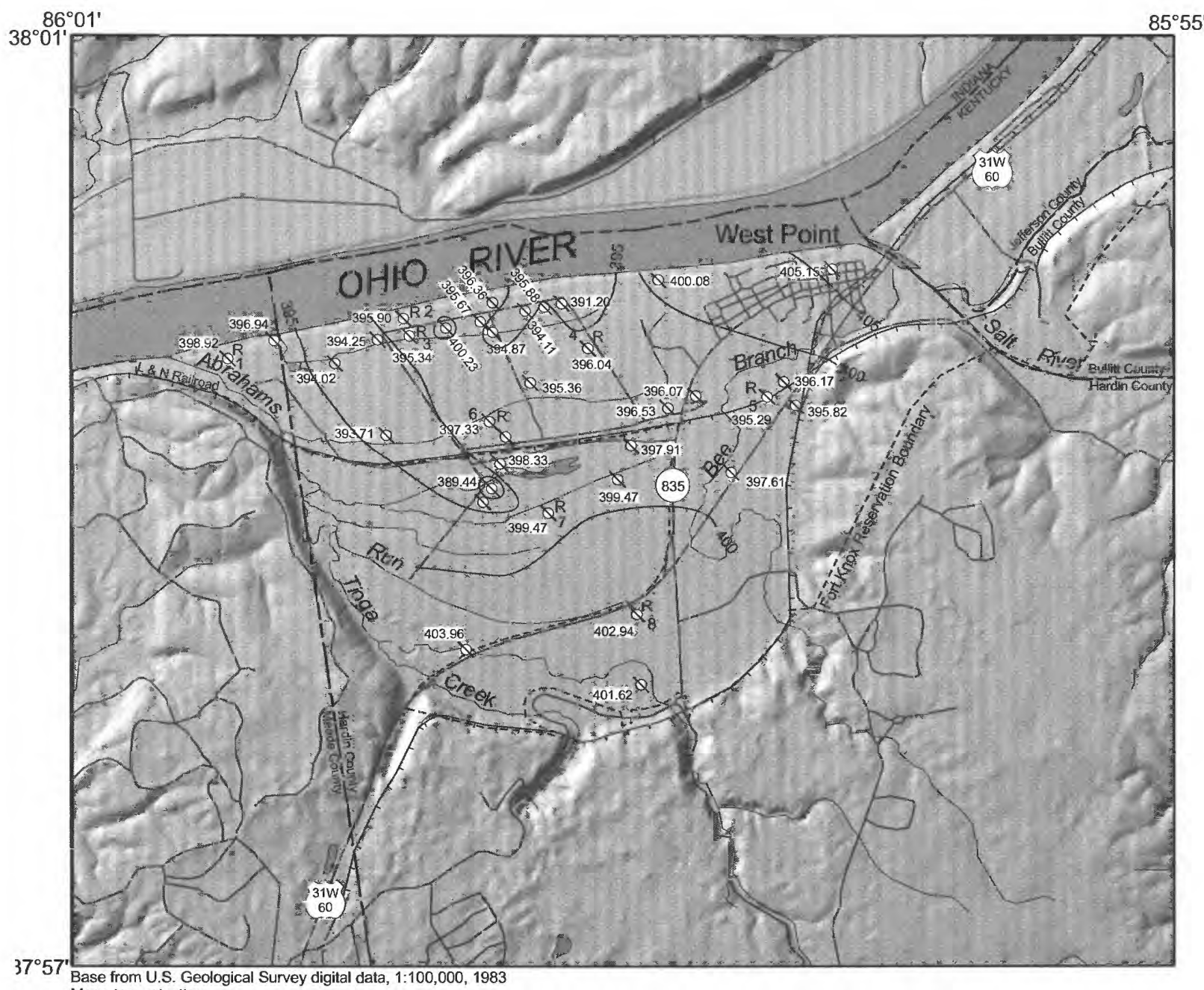

Base from U.S. Geological Survey digital data, 1:100,000, 1983
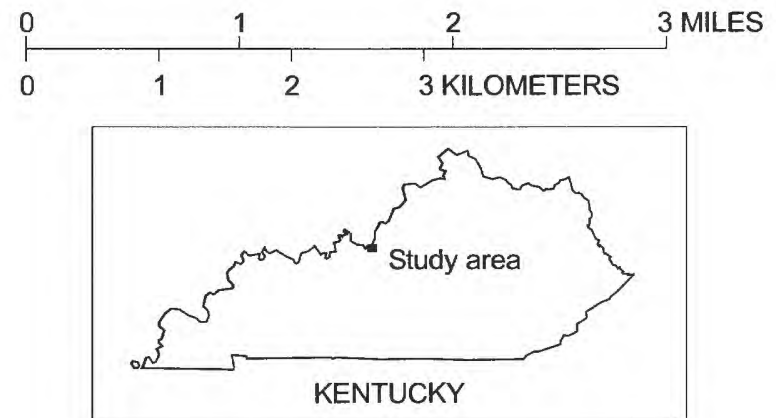

\section{EXPLANATION} - W00 - WATER-LEVEL CONTOURS - Showing altitude of water
level. Contour interval 5 feet; datum is sea level

Q Observation well without continuous recorder

$Q_{6}^{R} \quad$ Observation well with continuous recorder

Figure 5. Water levels in selected wells of the alluvial aquifer, February 25-26, 1998. 


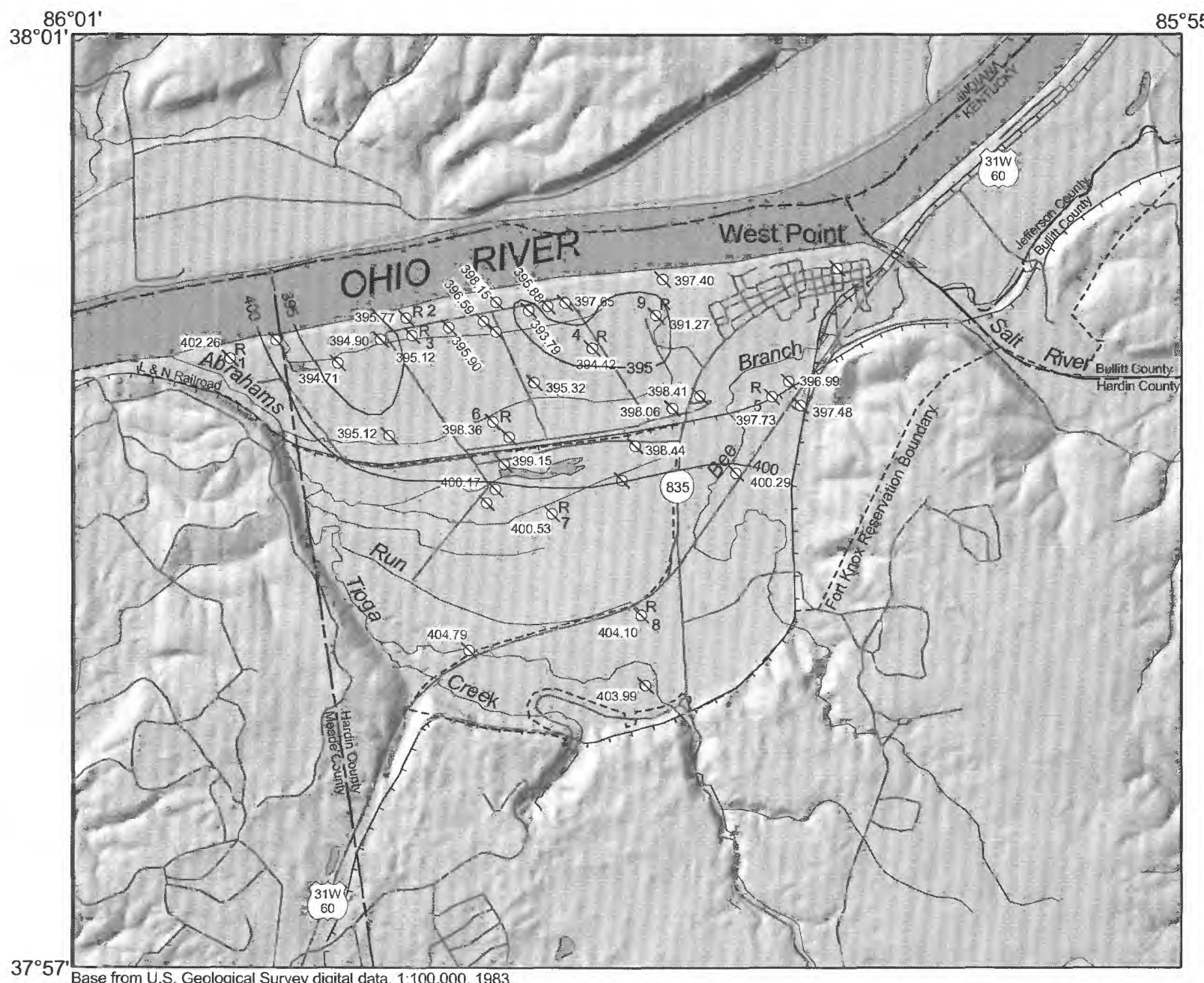

Base from U.S. Geological Survey digital data, 1:100,000, 1983
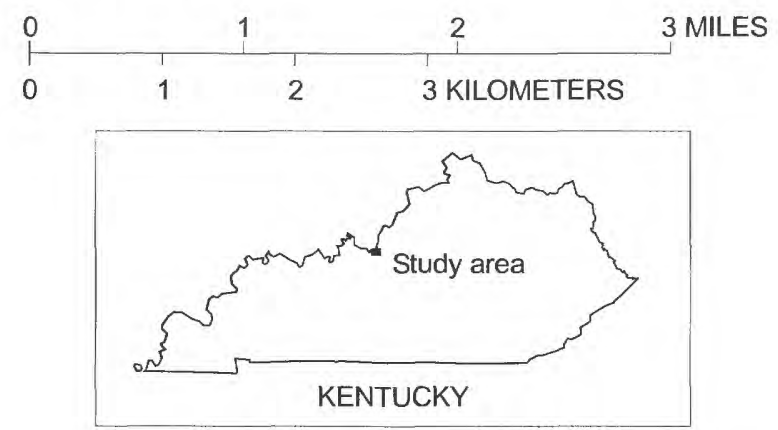

\section{EXPLANATION}

WATER-LEVEL CONTOURS - Showing altitude of water level. Contour interval 5 feet; datum is sea level

$-400-\quad$ level. Contour interval 5 feet; datum is sea level
$Q \quad$ Observation well without continuous recorder
$Q_{6}^{R} \quad$ Observation well with continuous recorder

Figure 6. Water levels in selected wells of the alluvial aquifer, June 16-18, 1998. 


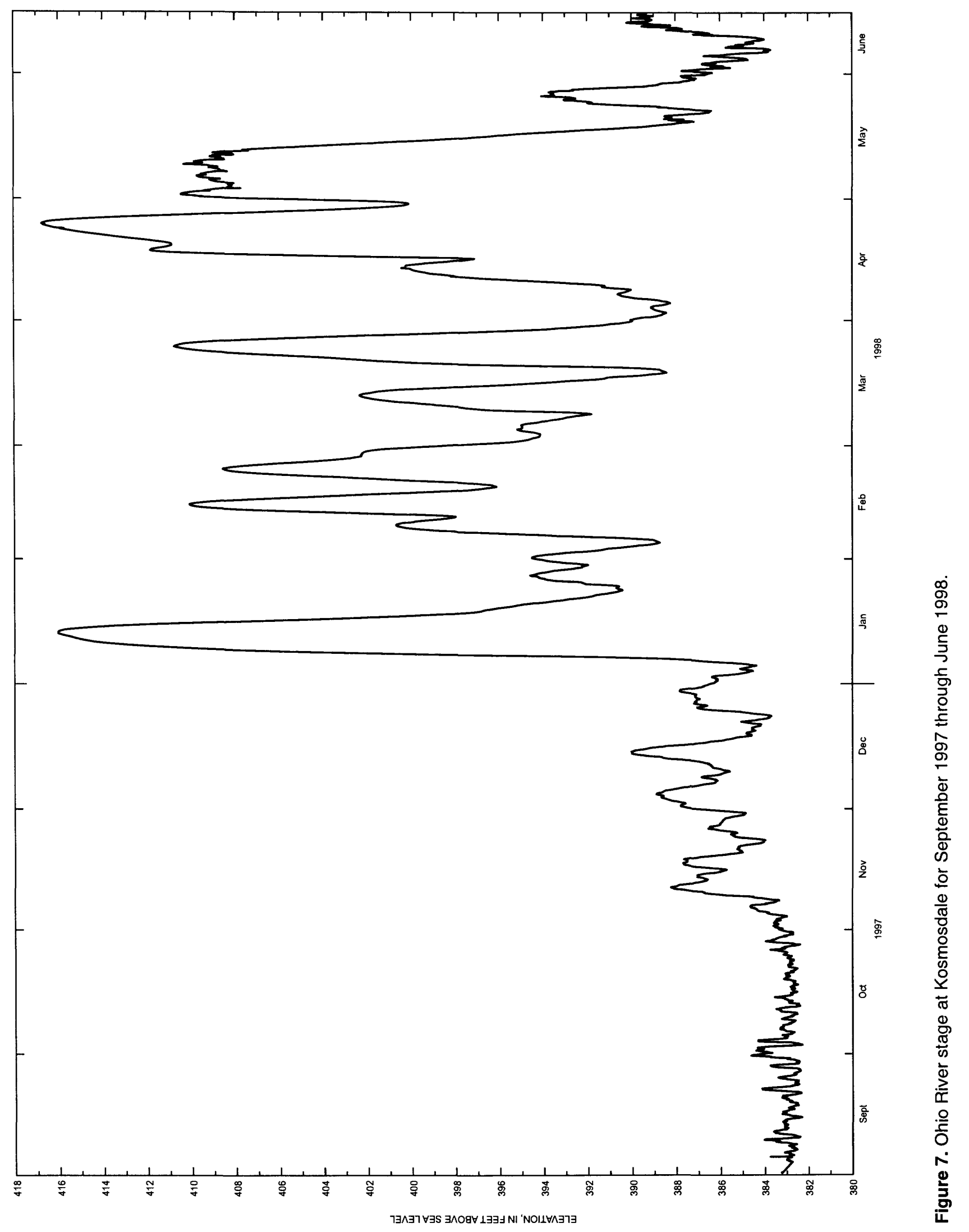




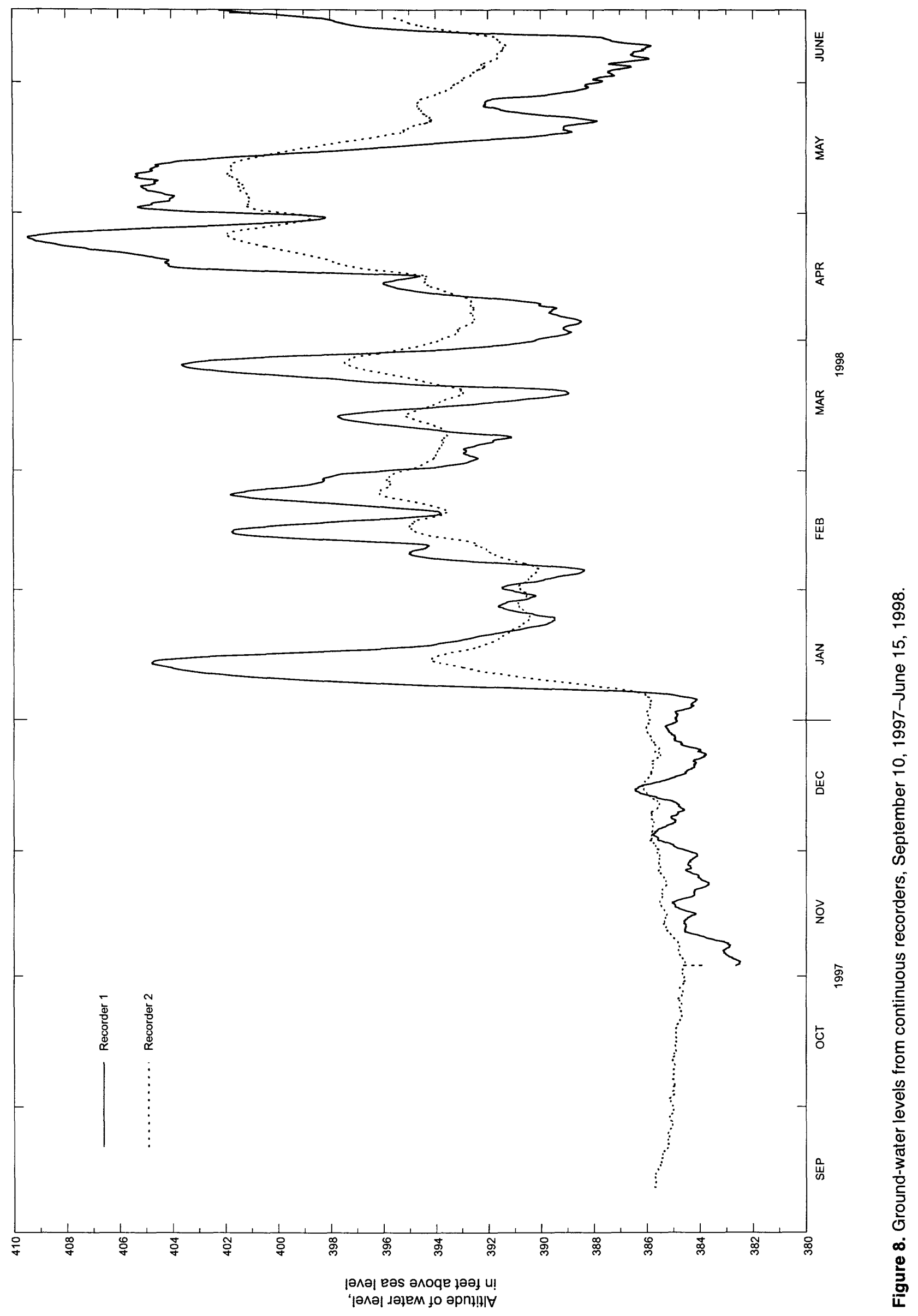




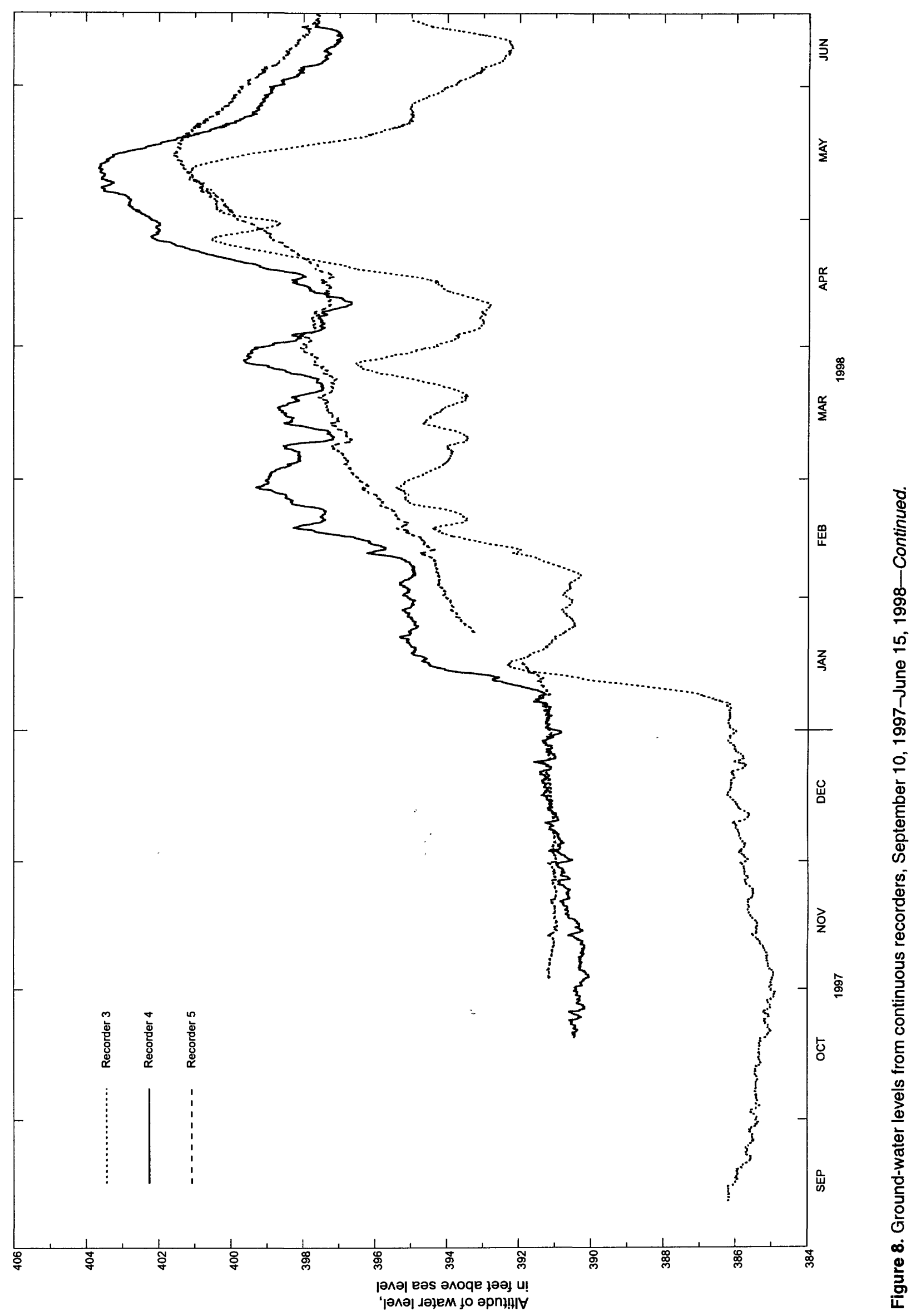




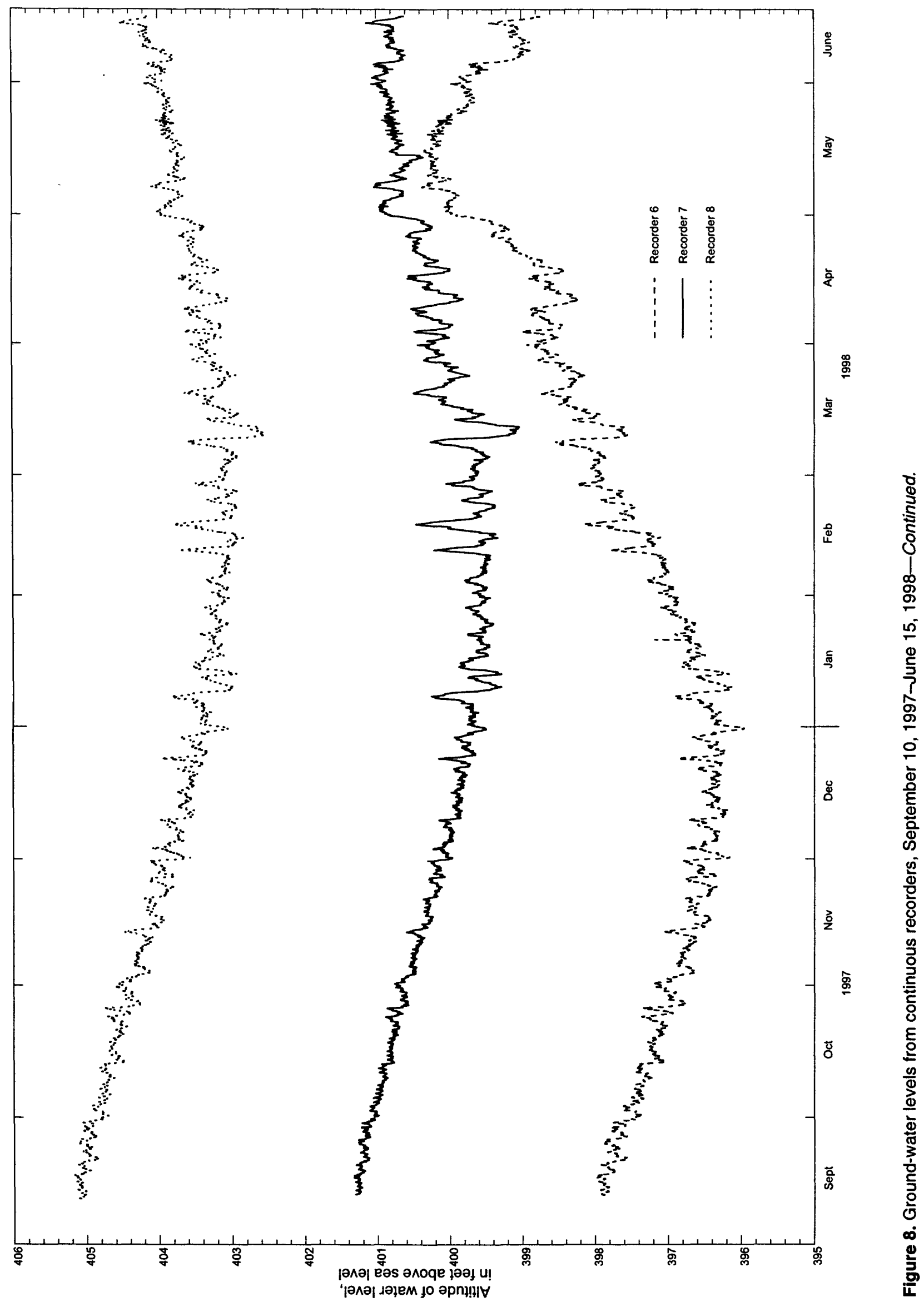


Upon closer inspection of the continuous-recorder data, a unique feature of the ground-water-flow system in the alluvial deposits was discovered. All of the continuous recorders measured simultaneous peaks in the study area. An example of this response is shown in figure 9. Recorder data for the period June 1-15, 1998 (fig. 9), shows uncommonly similar hydrographs for recorders numbered 6,7 , and 8 . A number of peaks have been indexed to highlight this response.

\section{Bedrock}

Initially, surveillance of water levels in the bedrock formations beneath the alluvial deposits was not considered. The shale of the Borden Formation was thought to be an aquitard not contributing or accepting flow from the alluvial deposits above; however, as the unique feature of corresponding simultaneous peaks in the alluvial deposit network was documented, efforts were made to monitor ground-water levels in the bedrock. Six abandoned oil-and-gas wells and one active gas well was inventoried as part of this investigation from a potential set of 32 oil-and-gas wells with locations on file at the Louisville Gas and Electric Company (LG\&E) and USGS offices in Louisville (fig. 10). The locations of the inventoried wells are shown in figure $10(8,12,14$, $25,27,28$, and 32 ); well 8 is the active gas well supplying natural gas to a private dwelling and farm. Well 25 had standing water in its casing and was open to a depth of over $340 \mathrm{ft}$ below land surface, but a hydrograph from a continuous recorder installed for 4 weeks showed no change in water levels. Therefore, it was assumed that this well was not hydraulically connected to either the alluvial aquifer or any other deep, waterbearing formation. Wells 28 and 12 were obstructed at depths of 40 and $10 \mathrm{ft}$, respectively. Well 27 was flowing at land surface, and well 13 was inaccessible for measuring. Access was gained to well 32 and a continuous recorder was installed and operated from April 1998 through January 1999. The total depth of the well was measured at approximately $190 \mathrm{ft}$ below land surface. Table 1 summarizes the status of the abandoned oil-and-gas wells in the study area.

A water-level hydrograph for well 32 is presented in figure 11. A 2-day hydrograph, with the recorder set on a 1-minute data acquisition interval, is presented in figure 12. In addition to the obvious unique water-level response, the hydrograph from the bedrock well also displays the same simultaneous peaks as recorded in the alluvial deposit wells. An example of this condition is shown in figure 13.

\section{Precipitation}

A record of daily precipitation is kept at the National Weather Service office in Louisville, Ky., approximately $15 \mathrm{mi}$ northeast of the study area. The total precipitation recorded for the Louisville metropolitan area for the period September 1996-August 1998 was 101.89 in., resulting in a departure of +13.11 in. from normal. Table 2 lists the monthly totals and their departure from normal.

\section{Ground-Water Pumpage}

Ground water is used in the study area primarily for public- and domestic-drinking-water supplies. Three public water-supply systems operate well fields in the study area. They are Hardin County Water District No. 1, West Point Municipal Water Works, and the U.S. Army Installation at Fort Knox. Table 3 summarizes the ground-water withdrawals inventoried for use in the model simulation. The location of well fields, pumpage volume, and number of operational wells are shown in figure 14.

\section{Hydraulic Conductivity}

A series of slug tests were done as part of this investigation to determine in place hydraulic conductivity values for the alluvial deposits. Ten wells were tested by quickly inserting and then removing a solid cylinder of known volume, thereby displacing an equal amount of water, and measuring the instantaneous change in water level. The recovery of the water level with time was recorded using a pressure transducer set on a logarithmic time scale for data acquisition. All wells tested were 2 -in. in diameter with $10 \mathrm{ft}$ of slotted screen (screen openings of $0.10 \mathrm{in}$.). A number of tests were made at each well with each test lasting approximately 20 seconds because of the highly transmissive nature of the alluvial deposits. Data were analyzed using the Hvorslev method (Freeze and Cherry, 1979), and the average hydraulic conductivity value at each test site is presented in figure 15.

The calculated hydraulic conductivity values from the slug tests are of the same order of magnitude as values calculated from aquifer tests previously done in an area just west and down river from the study area. Values for hydraulic conductivity published in USGS Hydrologic Investigations Atlas HA-95 (Gallaher, 1964) ranged from 116 to $410 \mathrm{ft} / \mathrm{d}$. 

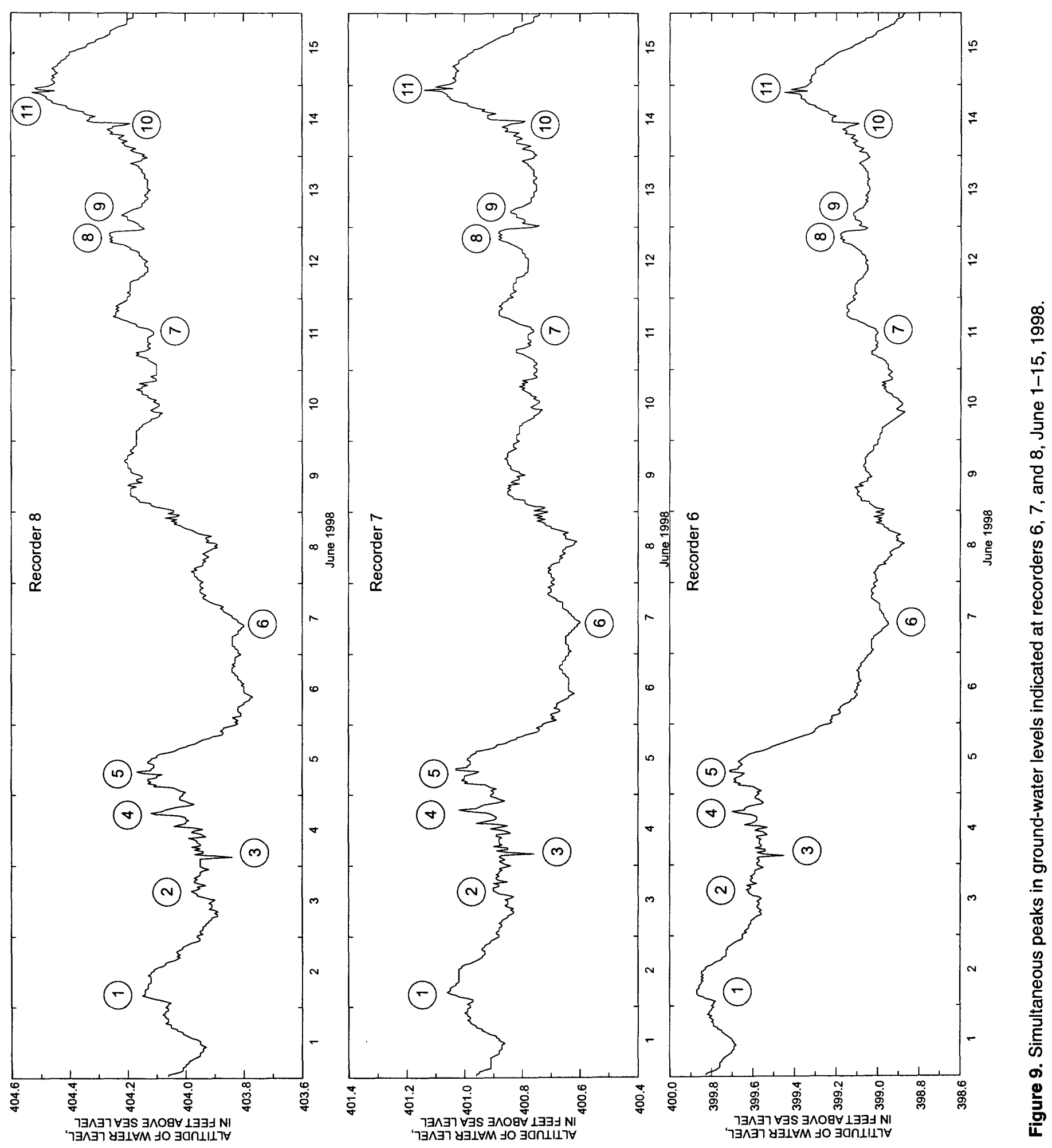


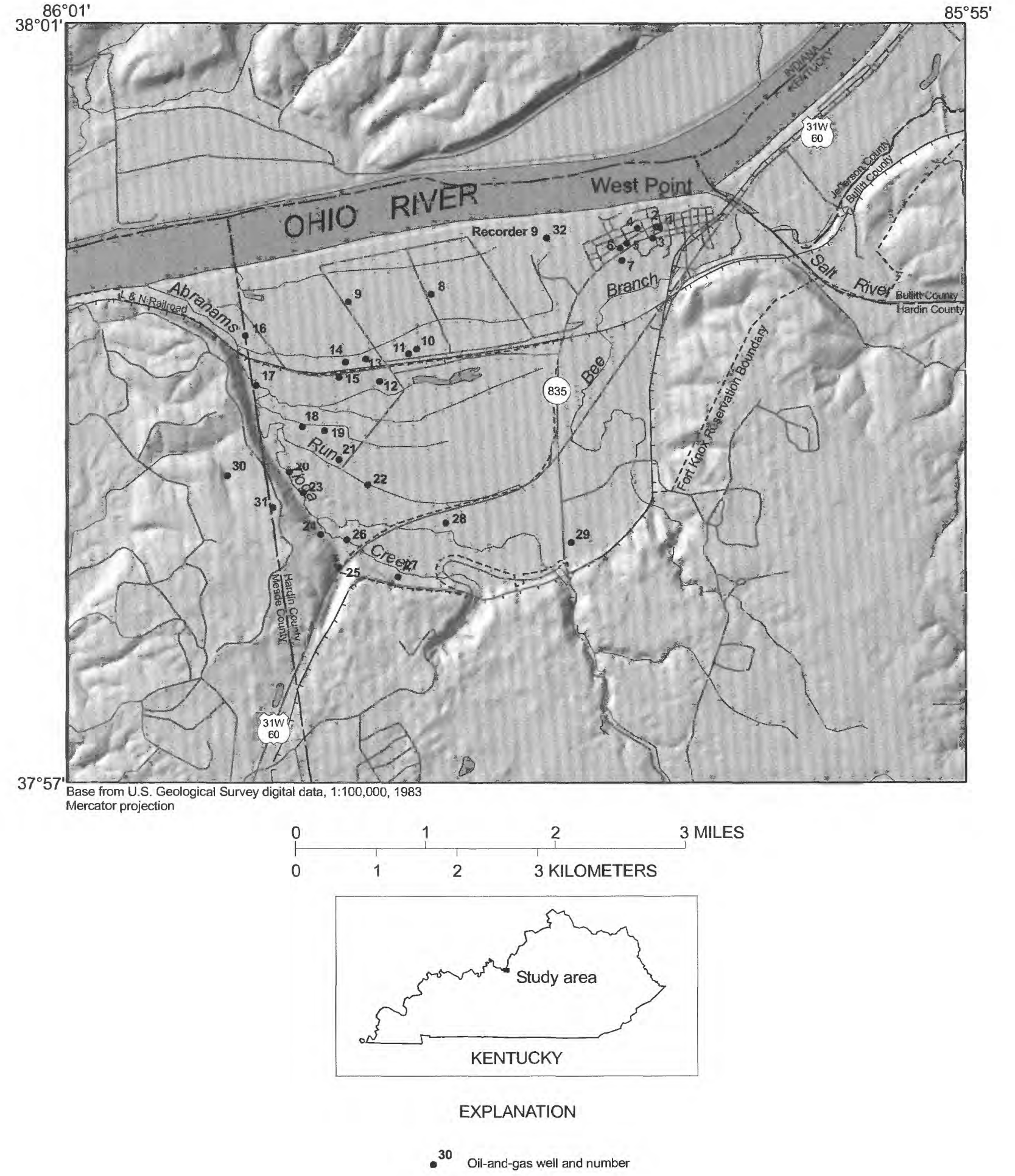

Figure 10. Location of oil-and-gas wells in the study area. 
Table 1. Status of abandoned oil-and-gas wells in the West Point area [\#, number]

\begin{tabular}{|c|c|c|c|c|}
\hline $\begin{array}{c}\text { Map } \\
\text { number }\end{array}$ & Latitude $^{1}$ & Longitude $^{1}$ & Local name & Remarks \\
\hline 1 & 375955 & 855702 & Unidentified & No attempt to verify location \\
\hline 2 & 375956 & 855704 & Unidentified & No attempt to verify location \\
\hline 3 & 375952 & 855706 & Unidentified & No attempt to verify location \\
\hline 4 & 375955 & 855712 & Unidentified & No attempt to verify location \\
\hline 5 & 375950 & 855716 & Unidentified & No attempt to verify location \\
\hline 6 & 375949 & 855718 & Unidentified & No attempt to verify location \\
\hline 7 & 375945 & 855718 & Unidentified & No attempt to verify location \\
\hline 8 & 375934 & 855834 & G. Gary & Domestic well; in service \\
\hline 9 & 375932 & 855907 & E. Mercer \#1 & $\begin{array}{l}\text { Previous investigation determined this well to be a } \\
\text { potential source of chlorides in the ground water }\end{array}$ \\
\hline 10 & 375917 & 855840 & Prewitt \#2 & No attempt to verify location \\
\hline 11 & 375916 & 855843 & Prewitt \#1 & No attempt to verify location \\
\hline 12 & 375907 & 855855 & McCormick \#1 & Location verified; well blocked at 10 feet \\
\hline 13 & 375914 & 855900 & Franzelle \#50 & Location verified; well is capped \\
\hline 14 & 375913 & 855908 & Franzelle \#1 & No attempt to verify location \\
\hline 15 & 375908 & 855911 & McCormick \#2 & No attempt to verify location \\
\hline 16 & 375921 & 855949 & E. Franzelle \#1 & No attempt to verify location \\
\hline 17 & 375905 & 855944 & Harris & Could not locate \\
\hline 18 & 375852 & 855926 & M. Franzelle \#2 & No attempt to verify location \\
\hline 19 & 375851 & 855917 & M. Franzelle \#1 & No attempt to verify location \\
\hline 20 & 375842 & 855931 & Palmer \#1 & No attempt to verify location \\
\hline 21 & 375842 & 855911 & Palmer \#2 & No attempt to verify location \\
\hline 22 & 375834 & 855900 & Ballinger-Mercer \#1 & No attempt to verify location \\
\hline 23 & 375832 & 855925 & Palmer \#4 & No attempt to verify location \\
\hline 24 & 375818 & 855918 & Ballinger-Mercer \#2 & Could not locate \\
\hline 25 & 375808 & 855911 & Round Hollow & Location verified; well open to 340 feet \\
\hline 26 & 375817 & 855908 & Ballinger-Mercer \#3 & Could not locate \\
\hline 27 & 375805 & 855847 & Athanas \#1 & Location verified; well flowing \\
\hline 28 & 375822 & 855828 & Marshall Realty & Location verified; well blocked at 40 feet \\
\hline 29 & 375816 & 855738 & Thomas & Could not locate; found old casing \\
\hline 30 & 375837 & 855955 & Harris \#2 & No attempt to verify location \\
\hline 31 & 375827 & 855938 & Palmer \#3 & No attempt to verify location \\
\hline 32 & 375952 & 855748 & E. Hart & $\begin{array}{l}\text { Inventoried for this investigation; continuous } \\
\text { recorder installed }\end{array}$ \\
\hline
\end{tabular}

\footnotetext{
${ }^{1}$ Degree, minute, and second symbols omitted.
} 


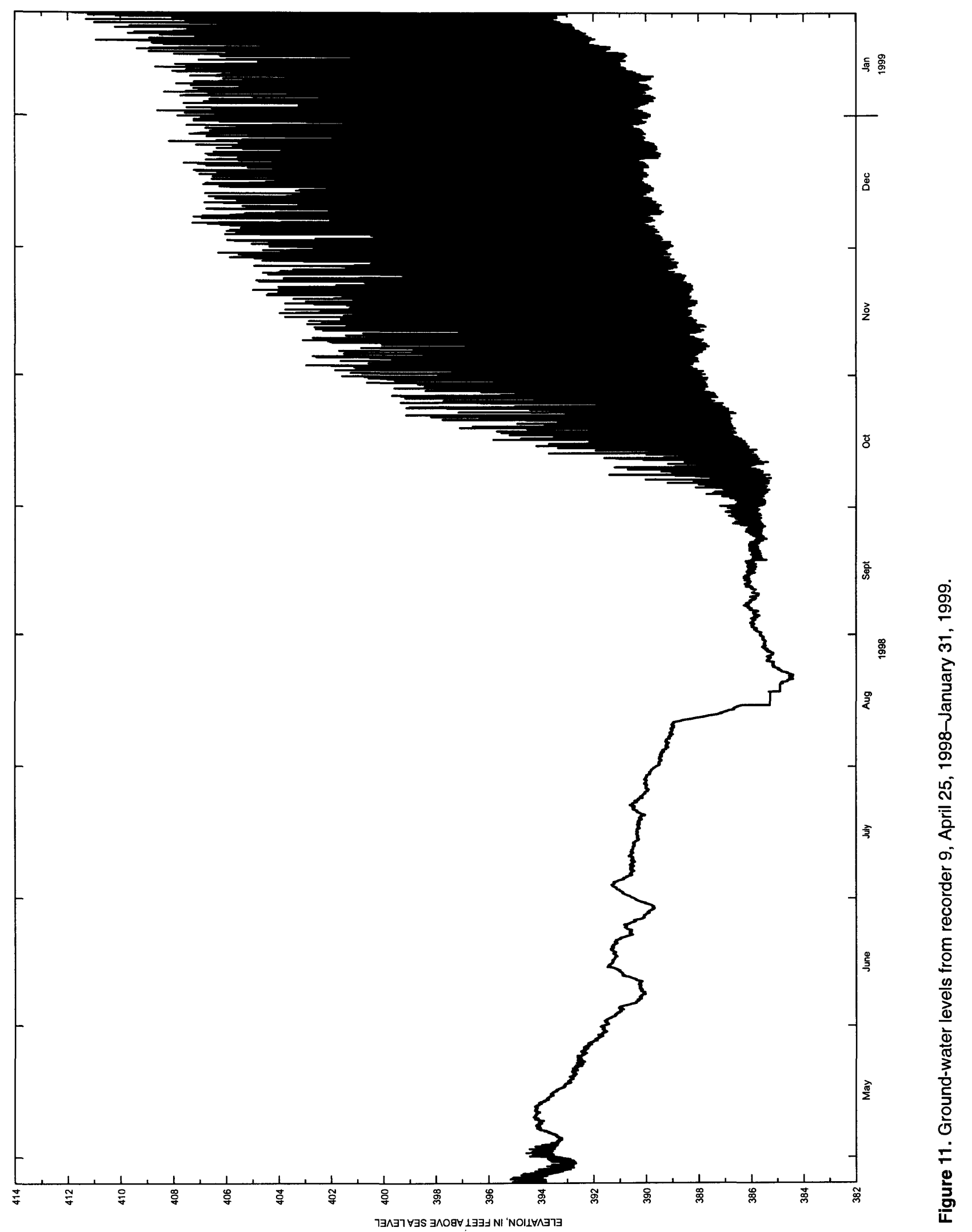




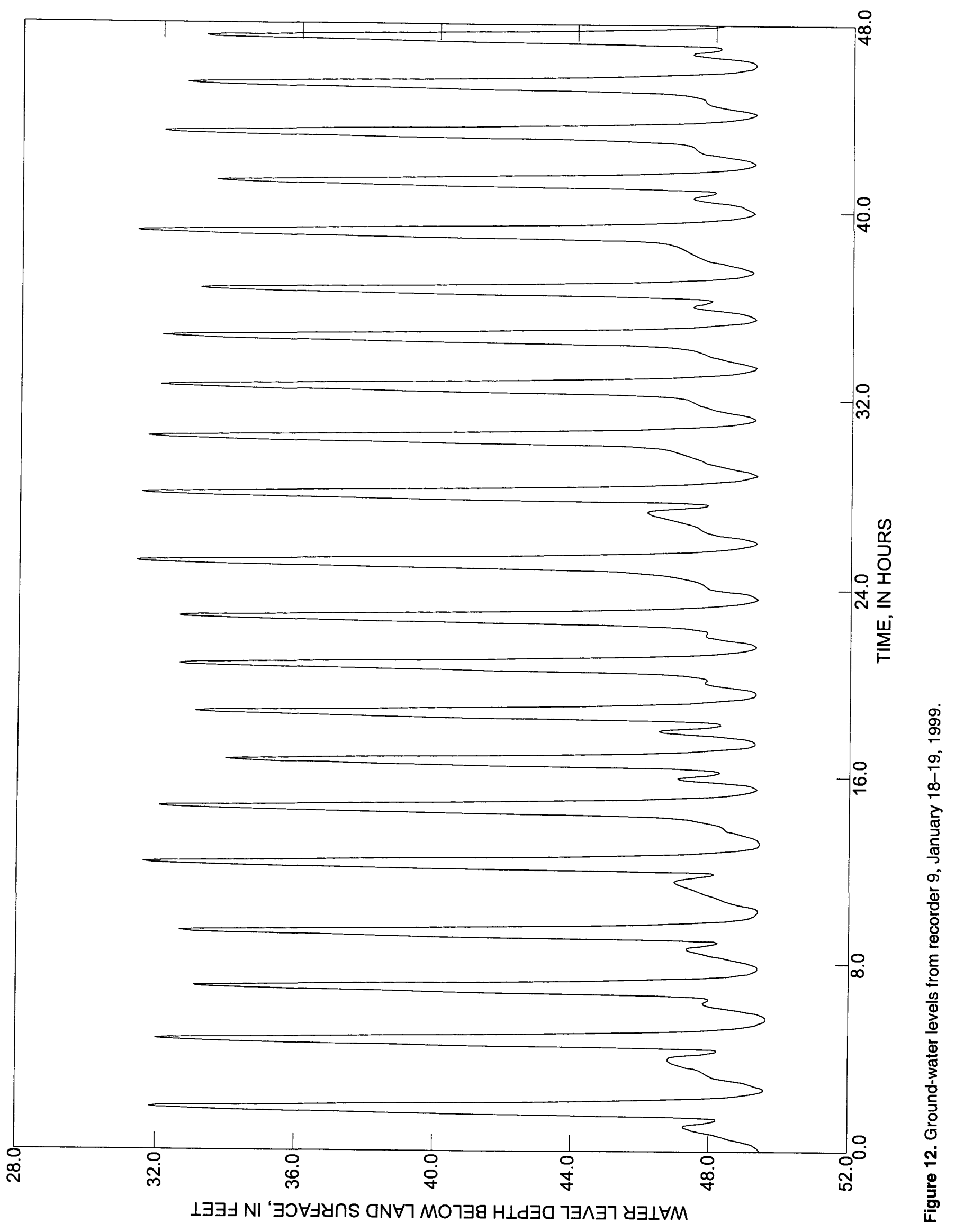




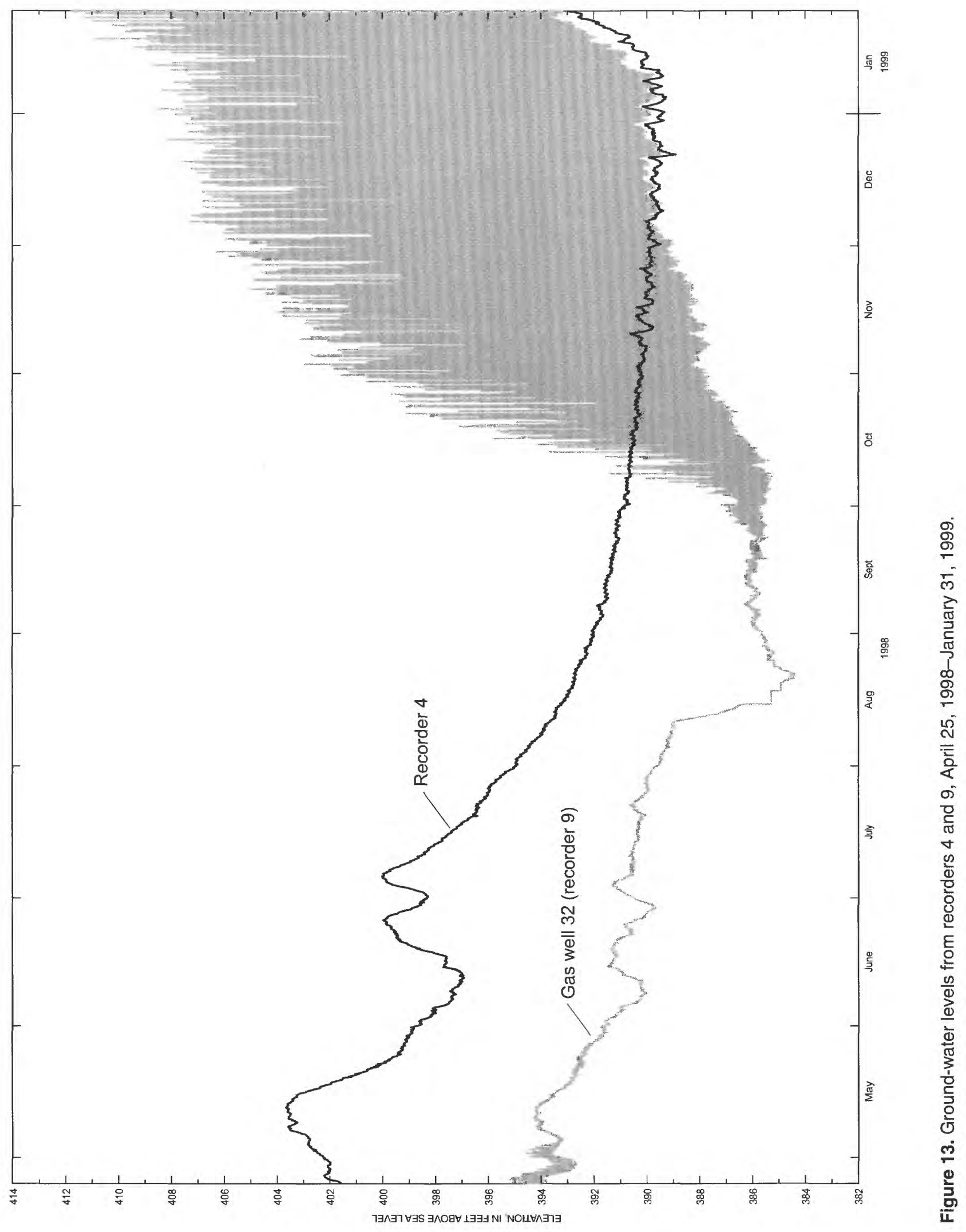


Table 2. Monthly precipitation totals at Louisville, Kentucky, September 1996-August 1998

\begin{tabular}{|c|c|c|}
\hline Month & $\begin{array}{l}\text { Amount } \\
\text { (inches) }\end{array}$ & $\begin{array}{l}\text { Departure } \\
\text { (inches) }\end{array}$ \\
\hline & $\underline{1996}$ & \\
\hline September & 5.63 & +2.47 \\
\hline October & 2.60 & -.11 \\
\hline November & 3.35 & -.35 \\
\hline \multirow[t]{2}{*}{ December } & 4.79 & +1.15 \\
\hline & 1997 & \\
\hline January & 3.37 & +.51 \\
\hline February & 3.39 & +.09 \\
\hline March & 12.58 & +7.92 \\
\hline April & 2.01 & -2.22 \\
\hline May & 6.01 & +1.39 \\
\hline June & 8.11 & +4.65 \\
\hline July & 1.74 & -2.77 \\
\hline August & 3.61 & +.07 \\
\hline September & 1.28 & -1.88 \\
\hline October & 1.41 & -1.30 \\
\hline November & 3.51 & -.19 \\
\hline \multirow[t]{2}{*}{ December } & 2.64 & -1.00 \\
\hline & 1998 & \\
\hline January & 2.80 & -.06 \\
\hline February & 2.88 & -.42 \\
\hline March & 3.88 & -.78 \\
\hline April & 6.69 & +2.46 \\
\hline May & 4.53 & -.09 \\
\hline June & 5.73 & +2.27 \\
\hline July & 6.89 & +2.38 \\
\hline August & 2.46 & -1.08 \\
\hline TOTAL & 101.89 & +13.11 \\
\hline
\end{tabular}

Table 3. Pumpage from public water-supply wells, West Point, Kentucky, November 1997

[Mgal/d, million gallons per day]

\begin{tabular}{ccc}
\hline Public water supplier & $\begin{array}{c}\text { Number } \\
\text { of wells }\end{array}$ & $\begin{array}{c}\text { Volume } \\
\text { pumped } \\
\text { (Mgal/d) }\end{array}$ \\
\hline Hardin County Water District No. 1 & 4 & 1.33 \\
West Point Municipal Water Works & 2 & .20 \\
U.S. Army Installation at Fort Knox & 12 & 2.34 \\
\hline
\end{tabular}

\section{HYDROGEOLOGY OF THE ALLUVIAL AQUIFER}

The study area lies within the Ohio River Physiographic Region of Kentucky. The exposed consolidated rocks in the area are of sedimentary origin and are of Mississippian age. The Mississippian rocks were eroded by glacial meltwater of the Pleistocene Epoch. A deep valley was excavated prior to the deposition of a thick body of sand and gravel. Ground water in the study area typically flows from the valley walls toward the Ohio River and discharges to the Ohio River and to water-supply wells.

\section{Geology}

Unconsolidated glacial outwash and alluvial deposits of Recent and Pleistocene ages that total about $100 \mathrm{ft}$ in thickness underlie the study area. These sediments are underlain by deposits of Early-Mississippian age New Providence Shale of the Borden Formation and New Albany Shale of Late-Devonian and EarlyMississippian age. Limestones of Devonian age underlie the New Albany Shale. These consolidated rocks are relatively uniform in structure and dip gently to the west; figure 16 shows a generalized columnar section of these units. The upland part of the study area consists of consolidated rocks of the Borden Formation (Muldraugh and Nancy Members) and St. Louis, Salem, and Harrodsburg Limestones (Kepferle and Sable, 1977). Figure 17 shows the generalized surficial geology of the study area.

\section{Alluvial Deposits}

During the Pleistocene Epoch, glacial meltwater eroded a deep valley through the study area, possibly formed by a cut-off meander from the main drainage of the region. The depth to the valley floor or bedrock surface from the present land surface ranges from $0 \mathrm{ft}$ at the base of the present-day valley walls to more than $100 \mathrm{ft}$ in some places of the study area. The Pleistocene valley was later filled with glacial outwash sand and gravel. The outwash material has an average thickness of approximately $60 \mathrm{ft}$ and is overlain by Ohio River flood-plain deposits of clay, silt, and fine sand that may be as much as $40 \mathrm{ft}$ thick in some areas. Figure 18 shows bedrock elevations and elevations of the fine-grained deposits in the study area that were compiled from 


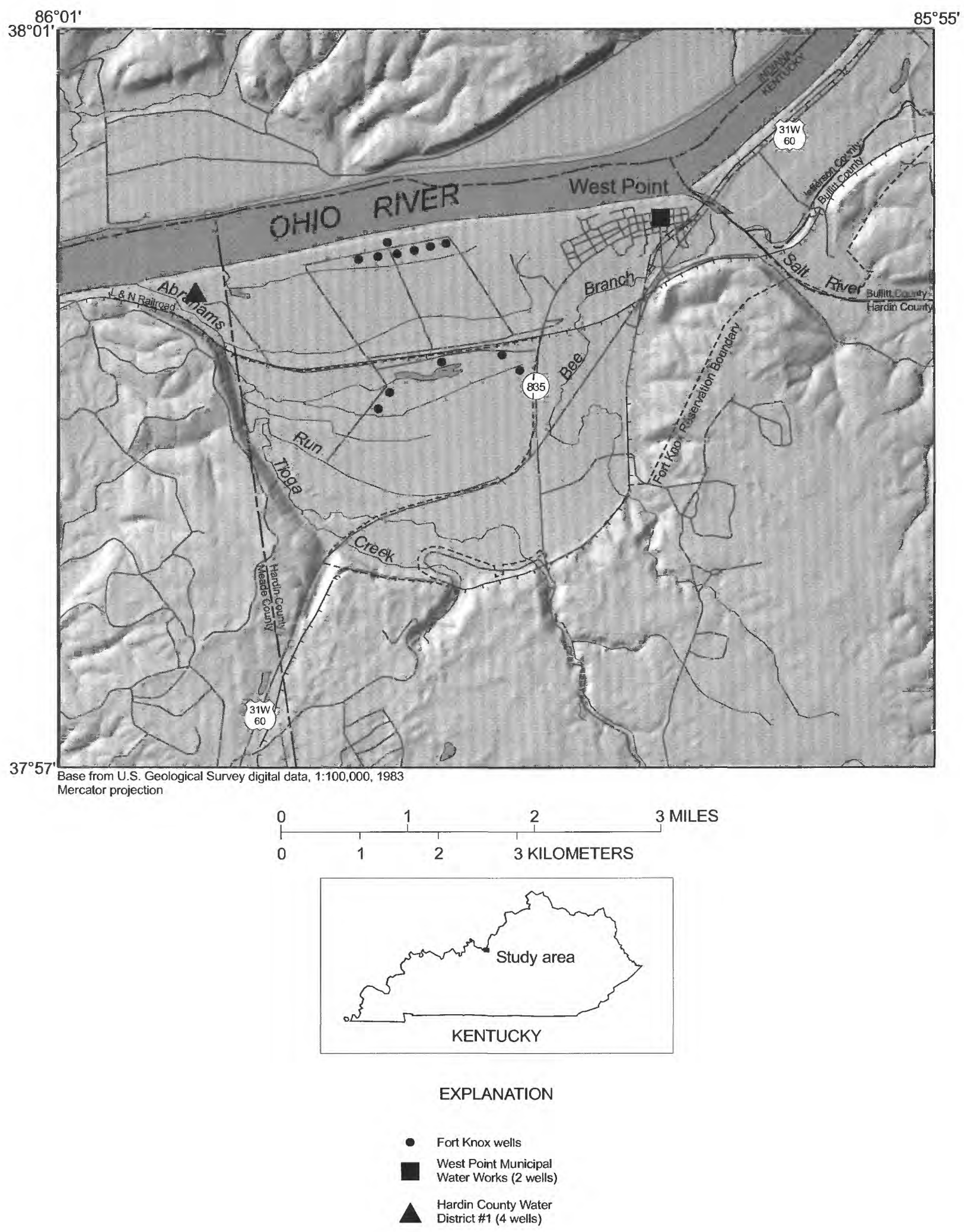

Figure 14. Location of public water-supply wells in the study area. 


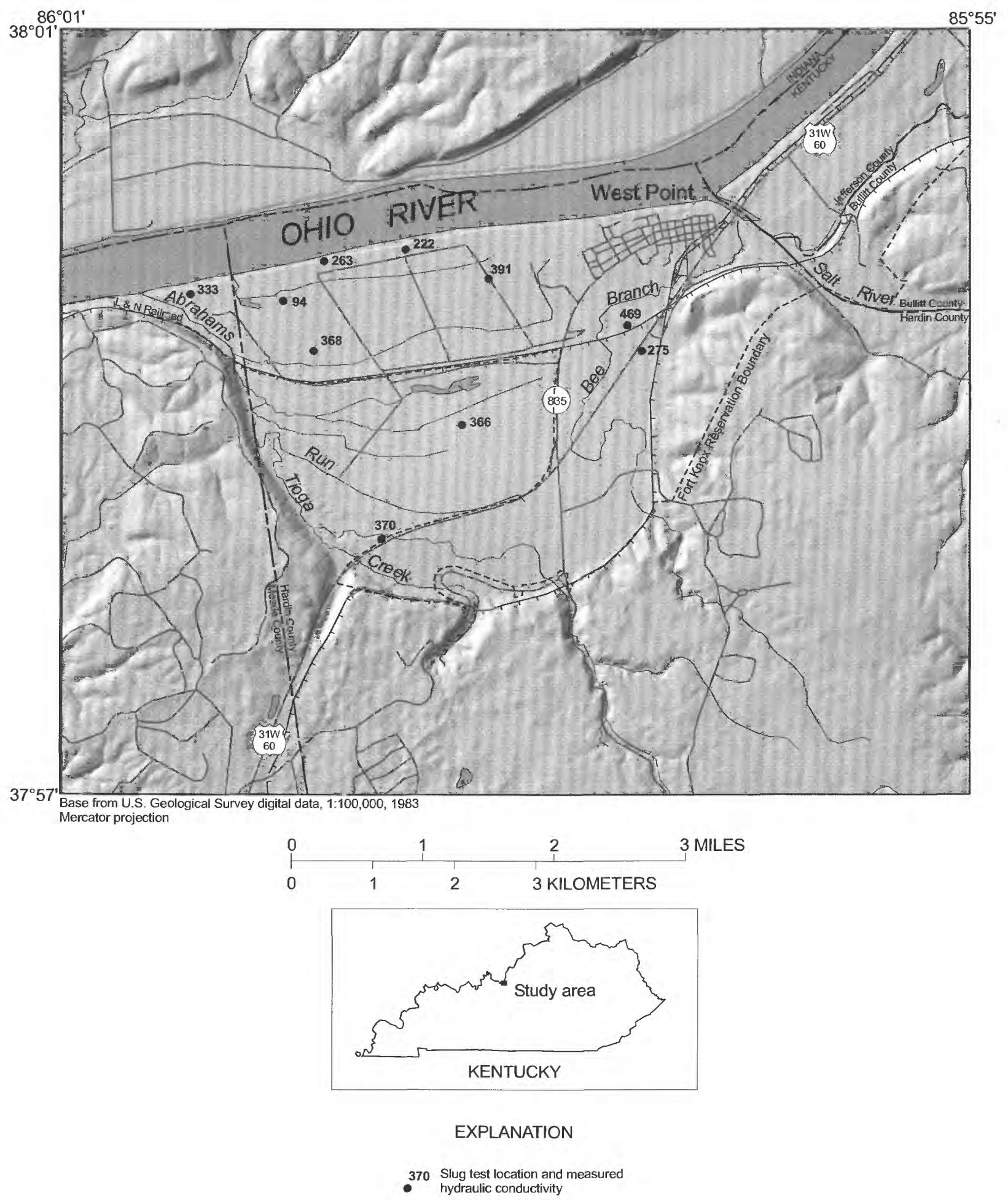

Figure 15. Location of slug tests and calculated hydraulic conductivities. 


\begin{tabular}{|c|c|c|c|c|}
\hline System & Series & $\begin{array}{c}\text { Formation } \\
\text { or } \\
\text { Group }\end{array}$ & $\begin{array}{l}\text { Thickness, } \\
\text { in feet }\end{array}$ & Description \\
\hline Quaternary & $\begin{array}{l}\text { Recent and } \\
\text { Pleistocene }\end{array}$ & Alluvium & $0-120$ & Silt, clay, sand, and gravel in Ohio River Valley. \\
\hline Mississippian & Osage & Borden group & 150 & $\begin{array}{l}\text { Shale, green to gray, clayey, contains iron oxide } \\
\text { concentrations at base. }\end{array}$ \\
\hline Devonian & $\begin{array}{l}\text { Upper } \\
\text { Devonian }\end{array}$ & $\begin{array}{l}\text { New Albany } \\
\text { Shale }\end{array}$ & 40 & Shale, black, fissile. \\
\hline Devonian & $\begin{array}{l}\text { Middle } \\
\text { Devonian }\end{array}$ & $\begin{array}{l}\text { Sellersburg } \\
\text { Limestone }\end{array}$ & $30+$ & $\begin{array}{l}\text { Massive dolomite and crinoidal crystalline limestone } \\
\text { and much chert. }\end{array}$ \\
\hline
\end{tabular}

Figure 16. Stratigraphy of major geologic units of the West Point area, north-central Kentucky (modified from Brown and Lambert, 1963).

previous investigations and drilling activities. Figure 19 is a cross-section first presented by Brown and Lambert (1963). It shows the unconsolidated deposits to be a well-mixed layer of silt, sand, and gravel.

\section{Bedrock}

A unique feature of the bedrock formation beneath the alluvial deposits is the Muldraugh gas field. Natural gas was produced from the "Corniferous" limestone of Devonian age and to a lesser extent from the New Albany Shale (Kepferle and Sable, 1977) underlying the alluvial deposits in the study area. A structure map drawn on the base of the New Albany Shale shows a structural high in the area of the Fort Knox well field (U.S. Geological Survey, unpub. data, 1969). Natural gas was present in a coral reef of the Sellersburg limestone. The New Albany and New Providence Shales formed a caprock trapping the gas in the limestone below. Numerous oil-and-gas exploratory and production wells were drilled in the area to extract the gas.

In the early 1950 's, the LG\&E converted the Muldraugh field to a gas-storage field. Natural gas is delivered to LG\&E by pipeline from natural gas fields in Texas, Louisiana, and Mississippi. Excess gas is pumped into the porous limestone and stored for later use. The gas storage field pressure is approximately 250 $\mathrm{lb} / \mathrm{in}^{2}$ and provides more than 2 billion $\mathrm{ft}^{3}$ of storage. The exact areal extent of the gas storage field is unknown but the gas injection/withdrawal well field is approximately $3 \mathrm{mi}$ west-southwest of the West Point area.

\section{Ground-Water Flow}

Ground-water flow in the alluvial deposits of the West Point area is typical of other Ohio River alluvial systems. Flow is generally from the upland or valley wall areas toward the Ohio River or other discharge points, principally pumped wells. Ground-water flow in the alluvial deposits of the West Point area may be affected by the possible contribution from or loss of water to the bedrock. Data from the water-level observation networks show that the ground water in both the alluvial deposits and the bedrock react similarly to an external stress.

\section{Alluvial Deposits}

Under normal conditions, regional ground-water flow in the alluvial deposits is predominantly horizontal from the alluvium/bedrock boundary at the valley wall 


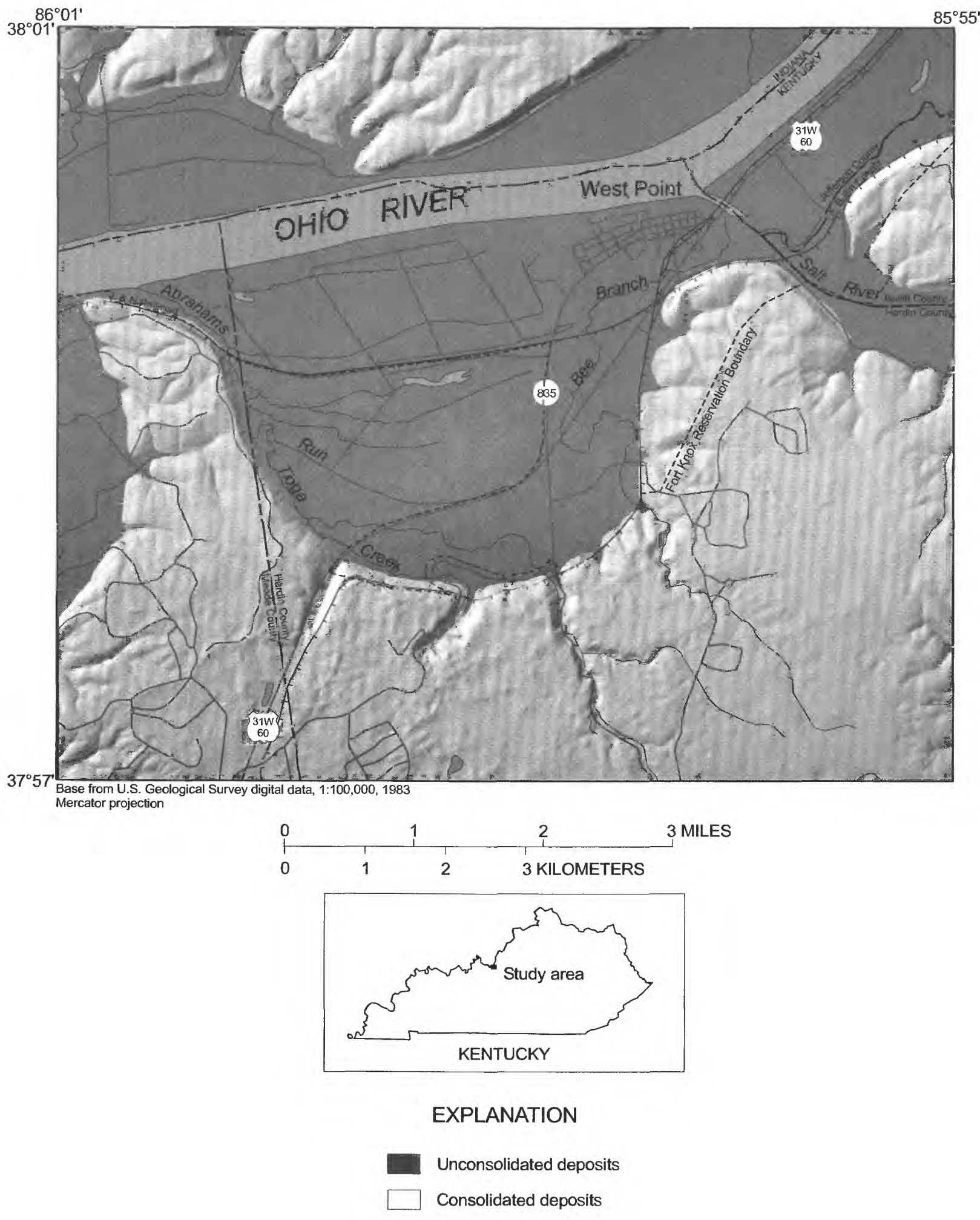

Figure 17. Generalized surficial geology of the study area near West Point, Kentucky. 


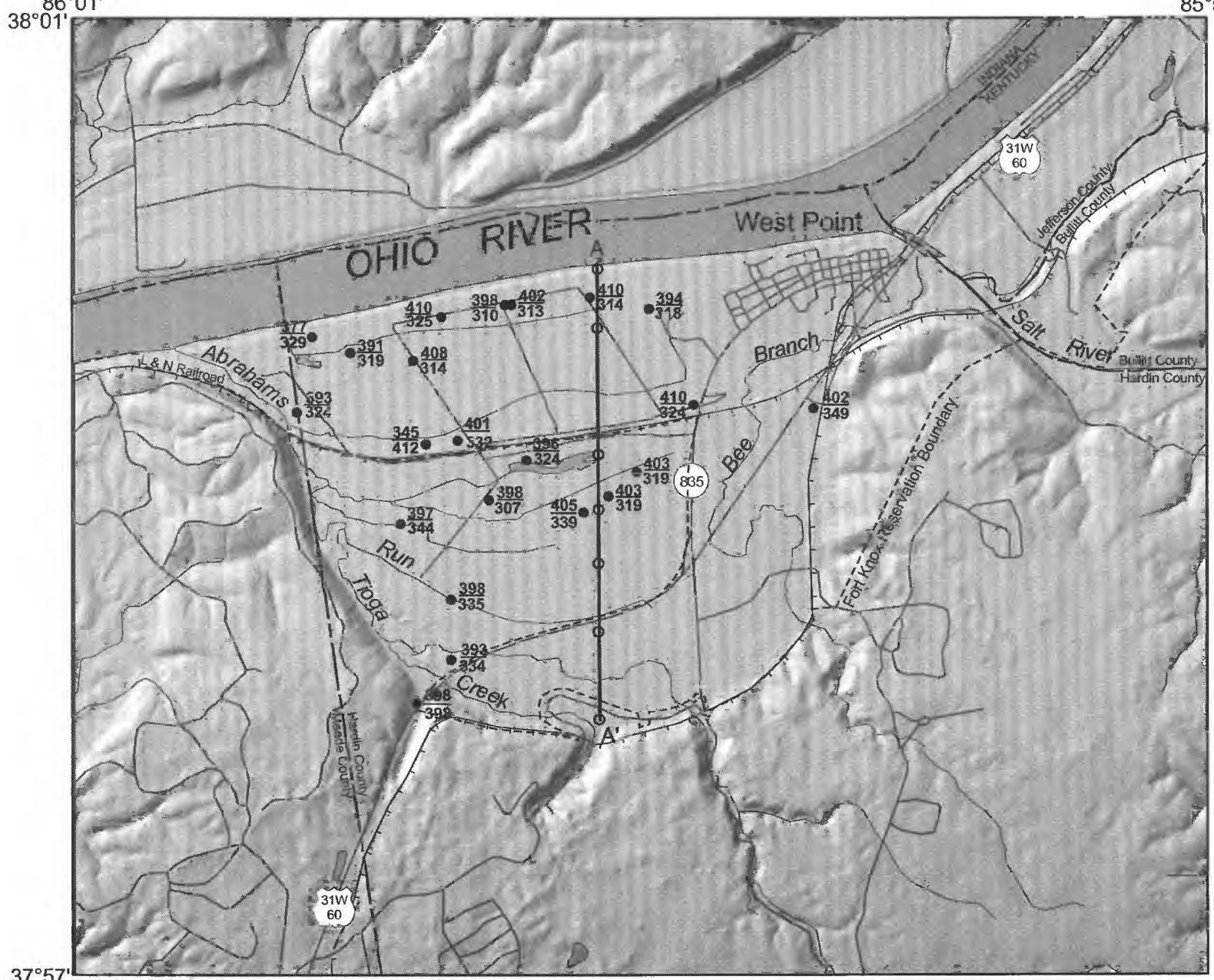

$37^{\circ} 57^{\prime}$ Base from U.S. Geological Survey digital data, 1:100,000, 1983 Mercator projection
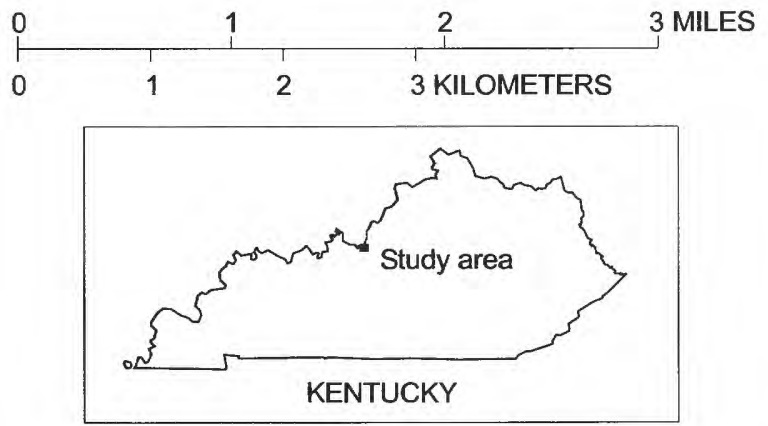

\section{EXPLANATION}

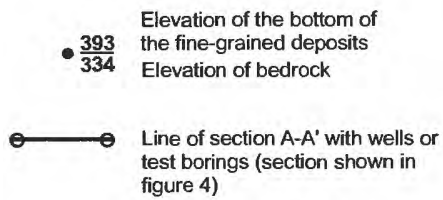

Figure 18. Elevations of the bottom of the fine-grained deposits (clay cap) and bedrock surface. 


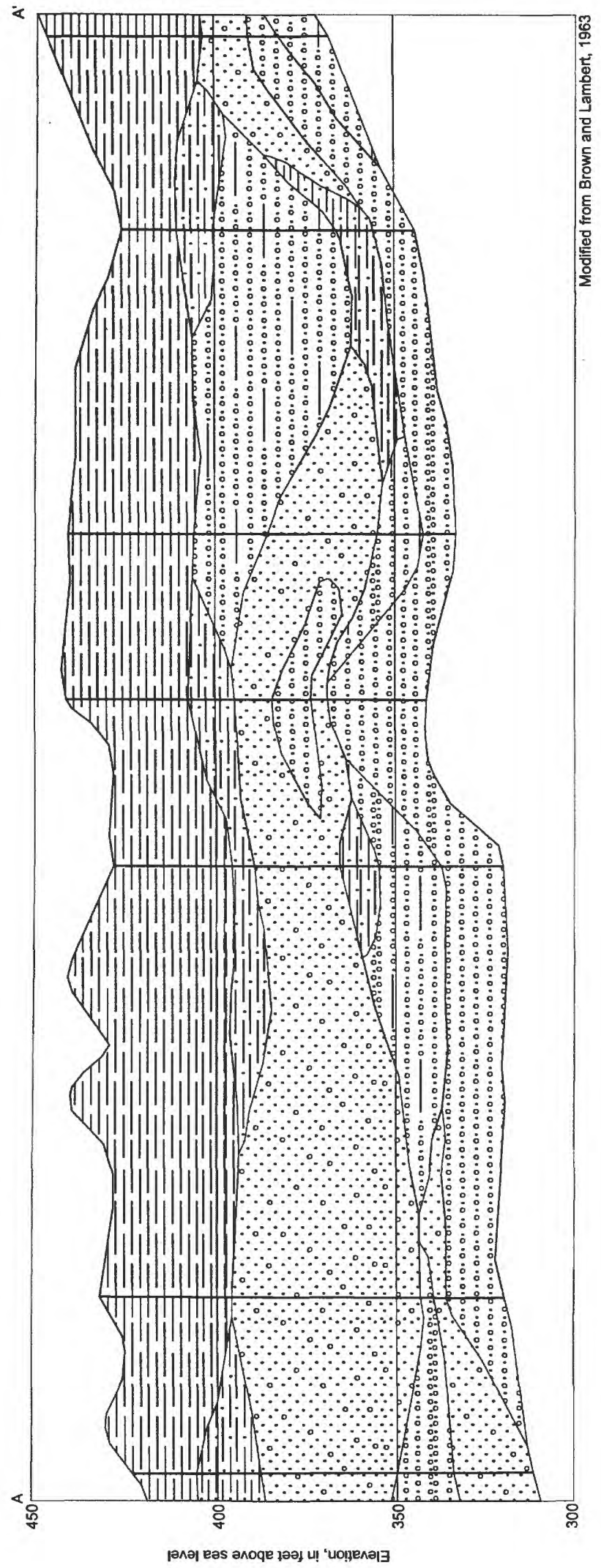

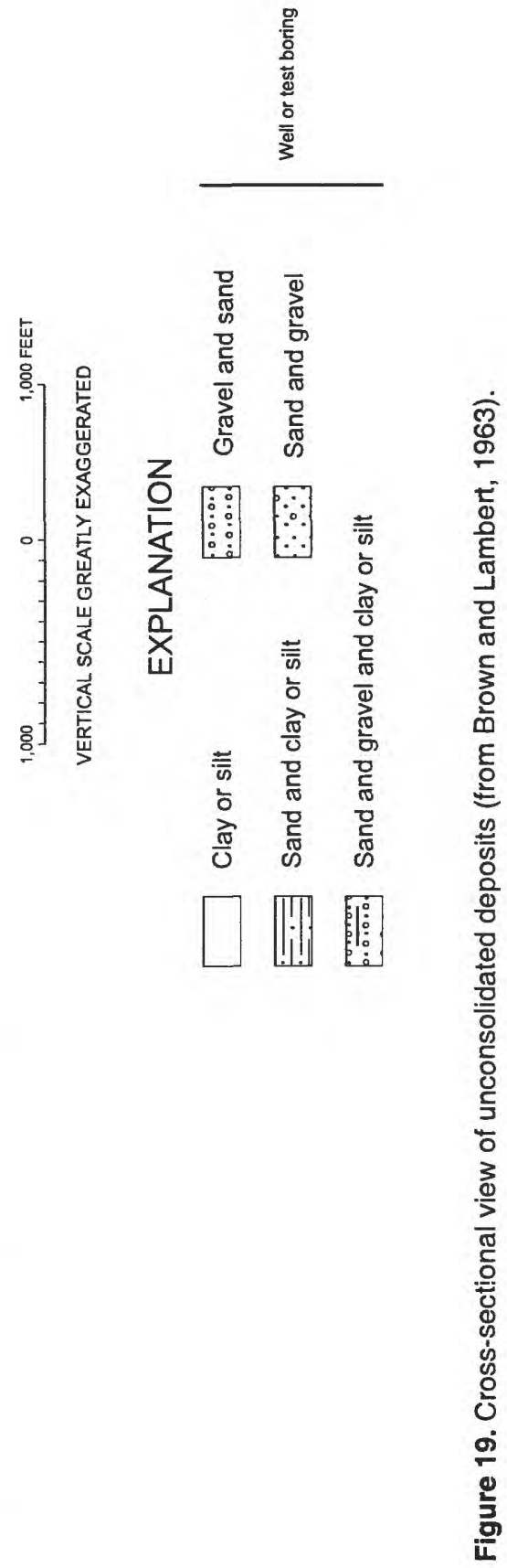


toward the Ohio River. This flow pattern is interrupted in areas of large ground-water withdrawals where slight cones of depression in the potentiometric surface have formed (fig. 3). Figure 20 shows the potentiometric surface in profile along section A-A' (plan view is shown in fig. 3) for October 1, 1997. The surface slopes from the valley wall toward the Ohio River with a dip caused by the withdrawal of water near recorder well 3 . Waterlevel measurements and lithologic data indicate the ground-water flow in the alluvial deposits to be unconfined. The water table may rise up into the area delineated as the fine-grained deposits, but this delineation is not exact.

Recharge to the alluvial deposits is from vertical infiltration of precipitation, flow from the valley wall, natural and induced infiltration from the Ohio River, and possibly flow upward from the bedrock beneath the alluvium. Rorabaugh (1956) estimated that approximately 6-12 percent of the annual precipitation in the Louisville area infiltrates the fine-grained deposits and becomes part of the ground-water-flow system. Additional recharge is probably received from the valley wall (lateral flow) as the water table slopes away from the wall toward the Ohio River, indicating a recharge boundary condition. The Ohio River provides a source of recharge to the alluvial deposits during periods of high river stage (flooding) when river water is "pushed" into the alluvium (fig. 21). River water is also induced into the alluvium in areas of ground-water withdrawals on or near the riverbank. Lastly, the alluvial deposits may receive recharge from the underlying bedrock during periods of the year when heads in the bedrock exceed the heads in the alluvial deposits (fig. 13).

Discharge from the alluvial deposits is by flow to the Ohio River (during normal and low-flow conditions on the river), to pumped wells, and possibly to the bedrock beneath the alluvium. Ground-water levels recorded in the abandoned gas well indicate a downward gradient from the alluvium to the bedrock during extended periods of the year. Further study is needed to adequately determine the nature of the water interaction between the alluvium and bedrock.

\section{Bedrock}

Monitoring of ground-water levels in the bedrock formations of the study area was not part of the data-collection activities initially planned for this investigation. As previously mentioned, unique water-level responses in the alluvial deposits underscored the need to monitor at depths to further refine the conceptualization of the ground-water-flow system(s). Unfortunately, only one acceptable bedrock well for water-level monitoring was inventoried during this investigation. Therefore, a description of flow within the bedrock over the study area is not possible and the discussion will instead concentrate on vertical flow and possible interaction with the alluvial deposits.

Hydrographs from recorder wells 4 (alluvium) and 9 (bedrock), presented in figure 13, show changing conditions during the course of monitoring for this investigation. Seemingly, water levels or heads in the alluvial deposits are higher than water levels in the bedrock for approximately 6 weeks of the year. During this period, there exists the possibility that the bedrock is receiving water from the alluvial deposits. At the end of September 1998, water levels in the bedrock start to react to an external stress, and by October, these levels are consistently exceeding the heads in the alluvial deposits. By December, a transition has occurred to where the static water levels in the bedrock exceed the heads in the alluvium and conditions exist for the bedrock to contribute water to the alluvial deposits. Further study is needed to determine the exact nature and conditions of flow in the bedrock of the study area.

\section{Effects of Gas-Storage Operation}

Natural gas is stored in the limestone formations near the West Point area by the LG\&E. Successful entrapment of injected gas and operation of the storage field depends, in part, on the impermeable nature of the caprock, which in this setting is the New Providence and New Albany Shale. As gas is stored in the limestone for future use, it is stored at a pressure that must not be greater than a predetermined fracturing pressure of the caprock. If the caprock is fractured, the stored gas and deep formation water could migrate upward, affecting shallow fresh-water aquifers (Smith, 1971).

In a typical storage reservoir, approximately onehalf of the storage space for the injected gas is created by the compression of the solid rock matrix (limestone), and the other half is created by the compression of the water in the pores of the rock. During the gas-storage season, injection pressures are set so as not to exceed the fracturing pressure of the caprock, and additional injection points are used to increase the size of the reservoir and not the pressure within the gas bubble. At the beginning of the gas-withdrawal season, the process is reversed. Pressure within the reservoir is reduced, and 


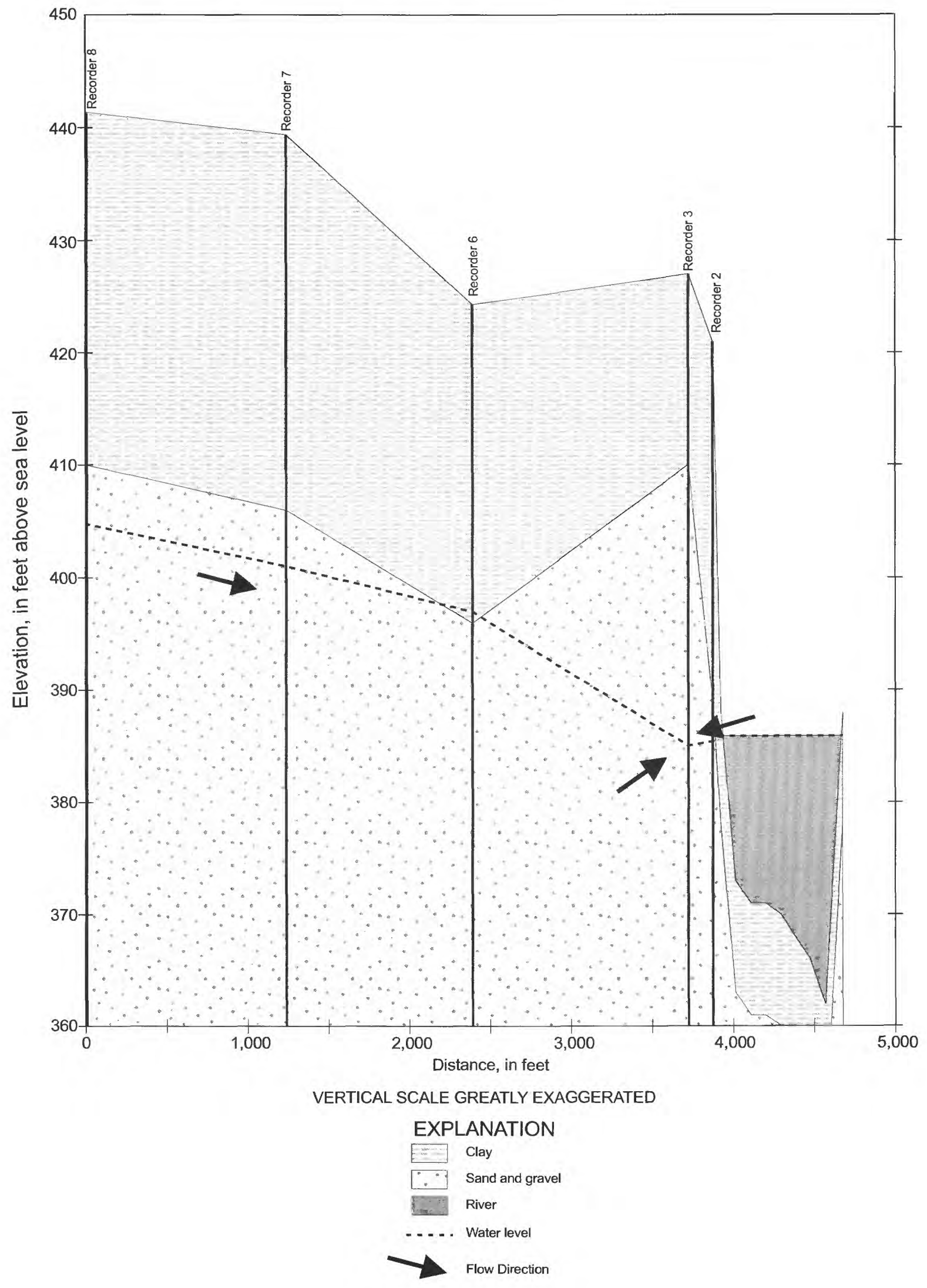

Figure 20. Profile of potentiometric surface, October 1, 1997. 


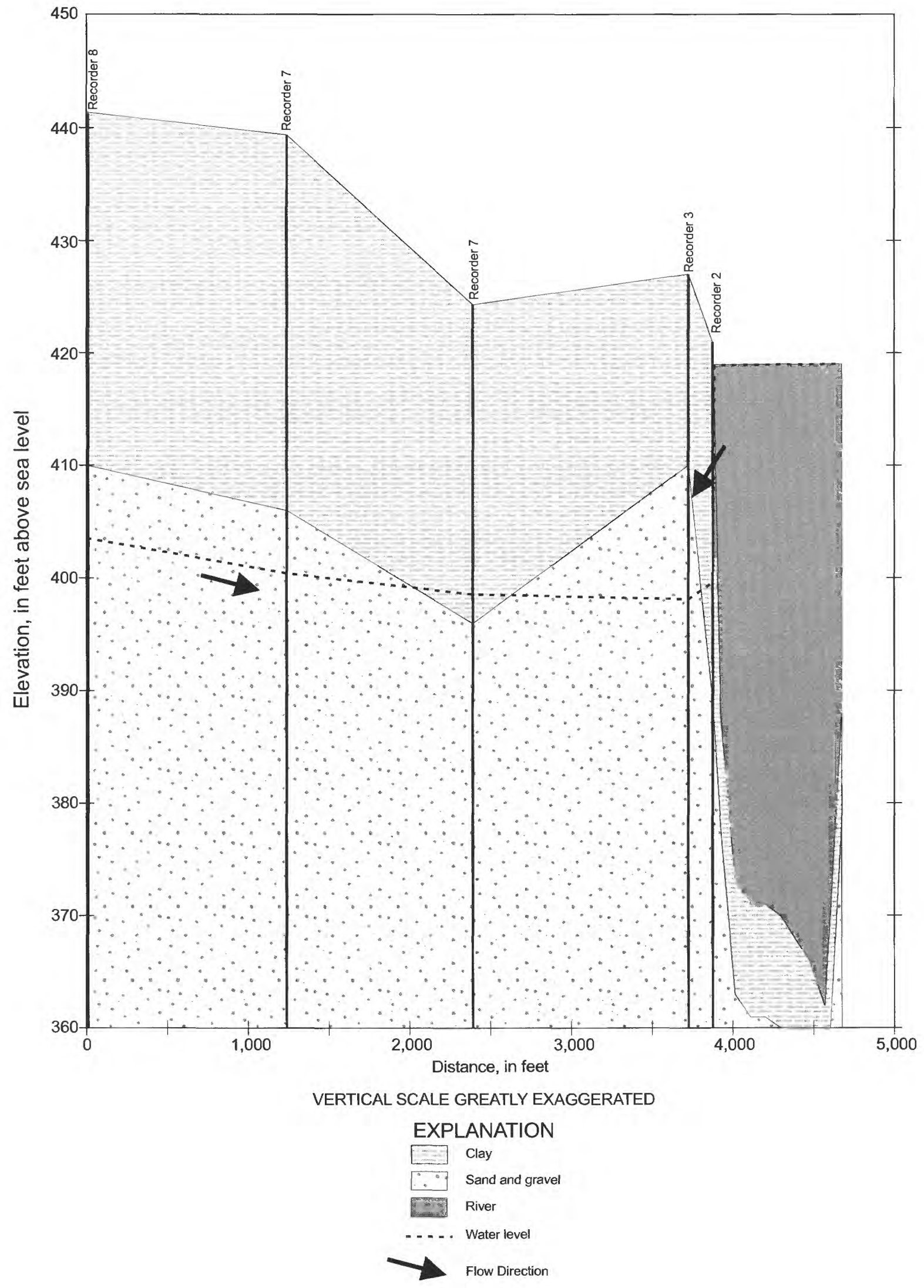

Figure 21. Profile of potentiometric surface, April 21, 1998. 
energy is released as the rock and water expand. Thus, the rock around the storage bubble acts like a large elastic reservoir. During the injection period, the rock is compressed, making room for more gas in the storage bubble. During the withdrawal period, the water-saturated rock expands, providing the energy to drive the water into the bubble and displace some of the gas from it (Buschbach and Bond, 1967).

The water-level hydrograph from recorder well 9 shows a response typical of a gas-storage operation. Maximum gas-storage pressure is reached in late spring. Pressures remain stable as the gas bubble expands in areal extent. As the heating season begins in the fall, gas withdrawals and repressurization of the storage field also starts. The hydrograph shows how the water in the bedrock responds to these changing conditions. Furthermore, the hydrograph from the recorder in the alluvial deposits (recorder well 4) shows a similar response, meaning the ground-water-flow system in the alluvium reacts to the same set of stresses.

\section{River-Aquifer Interaction}

Surface water is an important factor in the hydrologic framework of the West Point area. The Ohio River is a dominant feature and an integral part of the water budget of the ground-water-flow system. The Ohio River is hydraulically connected to the alluvial aquifer throughout its course in the study area. A series of seismic-reflection surveys were done on the Ohio River in the study area in an attempt to better characterize the depth and extent of the fine-grained riverbed sediments.

Figure 22 shows the survey traverses and a typical cross-section highlighting the distribution of fine- and coarse-grained deposits in the riverbed; the bedrock surface could not be delineated. Additional information regarding the techniques of seismic-reflection surveys and their application can be found in reports by Brabets (1995) and Haeni (1986).

Other surface streams in the study area were evaluated to determine their connection to the alluvial aquifer.

\section{Ohio River}

A system of locks and dams controls the navigational channel and stage for the Ohio River through a series of pools. The West Point area lies along the pool created by the Ohio River Dam at Cannelton, approxi- mately $105 \mathrm{mi}$ downstream. The water level in the pool adjacent to the study area is normally maintained at about $383 \mathrm{ft}$.

At normal pool stage, the Ohio River is generally a discharge point, or sink, for the ground-water-flow system. Water levels recorded during the November 1997 ground-water-level synoptic measurements show ground-water flow to be toward the river during periods of normal pool elevations (fig. 4). An exception to this condition exists in areas of withdrawals from wells near or on the riverbank. Pumping of ground water near the river can induce surface-water infiltration, thus reversing gradients in these areas. This condition is shown in figure 20 where there is pumping near recorder well 3 . During periods of high water on the Ohio River, ground-water gradients may flatten out or reverse, as the river water becomes a source of recharge to the alluvial aquifer (fig. 21).

The response of the ground-water levels in the alluvial aquifer to floodpulses from the Ohio River is another indication of the river's hydraulic connection with the alluvial aquifer. Hydrographs for the Ohio River and a pair of water-level observation wells are presented in figures $23 \mathrm{a}$ and $23 \mathrm{~b}$. The riverbank well (R2) is approximately $250 \mathrm{ft}$ from the river at normal pool stage; the distant well (R3) is approximately $600 \mathrm{ft}$ from the river at normal pool stage (fig. 3).

In January 1998, the Ohio River rose approximately $35 \mathrm{ft}$ and crested at 1600 hours on January 13 . Water levels in $\mathrm{R} 2$ peaked approximately 32 hours later, after a rise of approximately $8 \mathrm{ft}$; water levels in R3 peaked an additional 30 hours later with a $7 \mathrm{ft}$ rise. In March 1988, the Ohio River rose approximately $24 \mathrm{ft}$ and crested at 1400 hours on March 25. Water levels in R2 correspondingly rose about $4.5 \mathrm{ft}$ and peaked 26 hours after the river crested. Water levels in R3 rose approximately $3 \mathrm{ft}$ and peaked at 2000 hours on March 27 , some 54 hours after the river crested.

\section{Small Streams}

Two streams - Tioga Creek and Abrahams Runprovide most of the surface-water drainage in the study area. Drainage patterns are generally east to west. Baseflow of Tioga Creek is supplied by three springs: Dripping Spring, Poplar Spring, and Tioga Spring. Tioga Creek drains to Abrahams Run, which flows to the Ohio River at the extreme western edge of the study area. Two seepage runs during low-flow conditions were conducted as part of the investigation; calculation of 


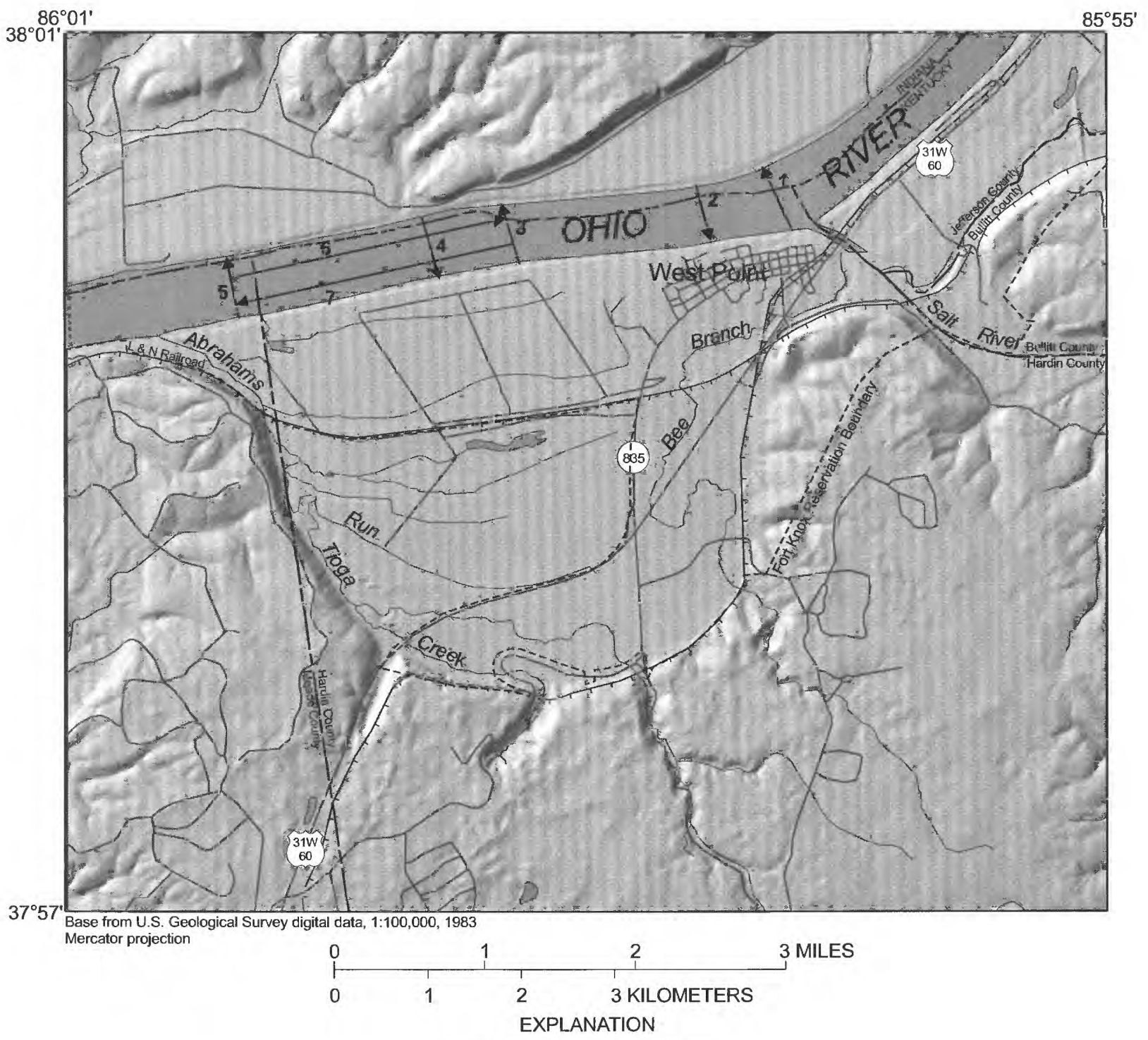

$\stackrel{2}{\longrightarrow}$ Seismic-reflection survey

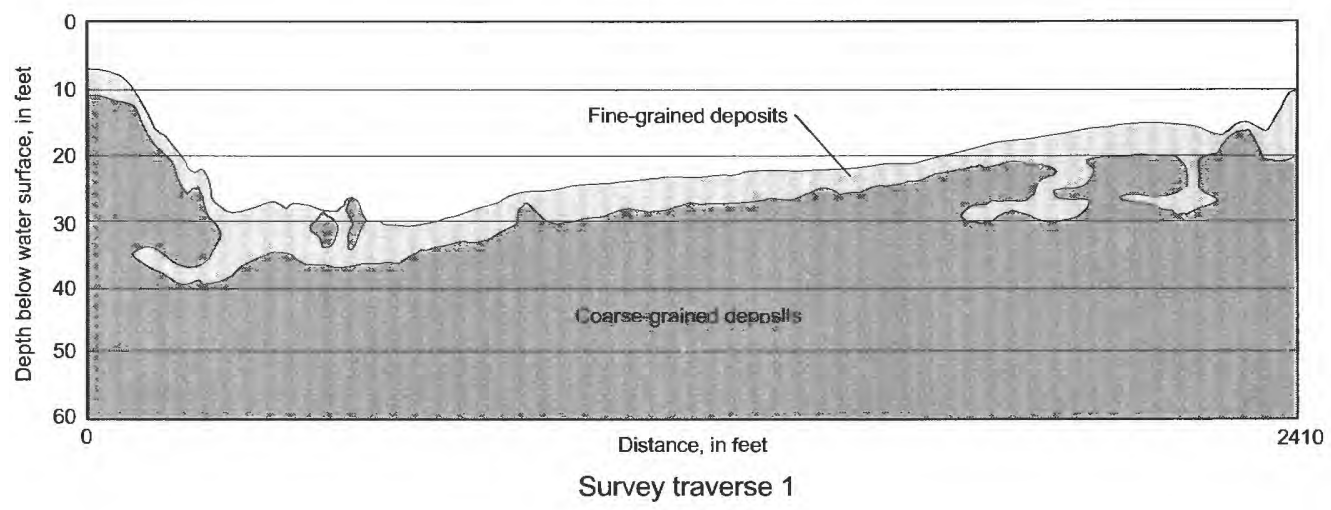

Figure 22. Location of seismic-reflection survey traverses and survey results. 


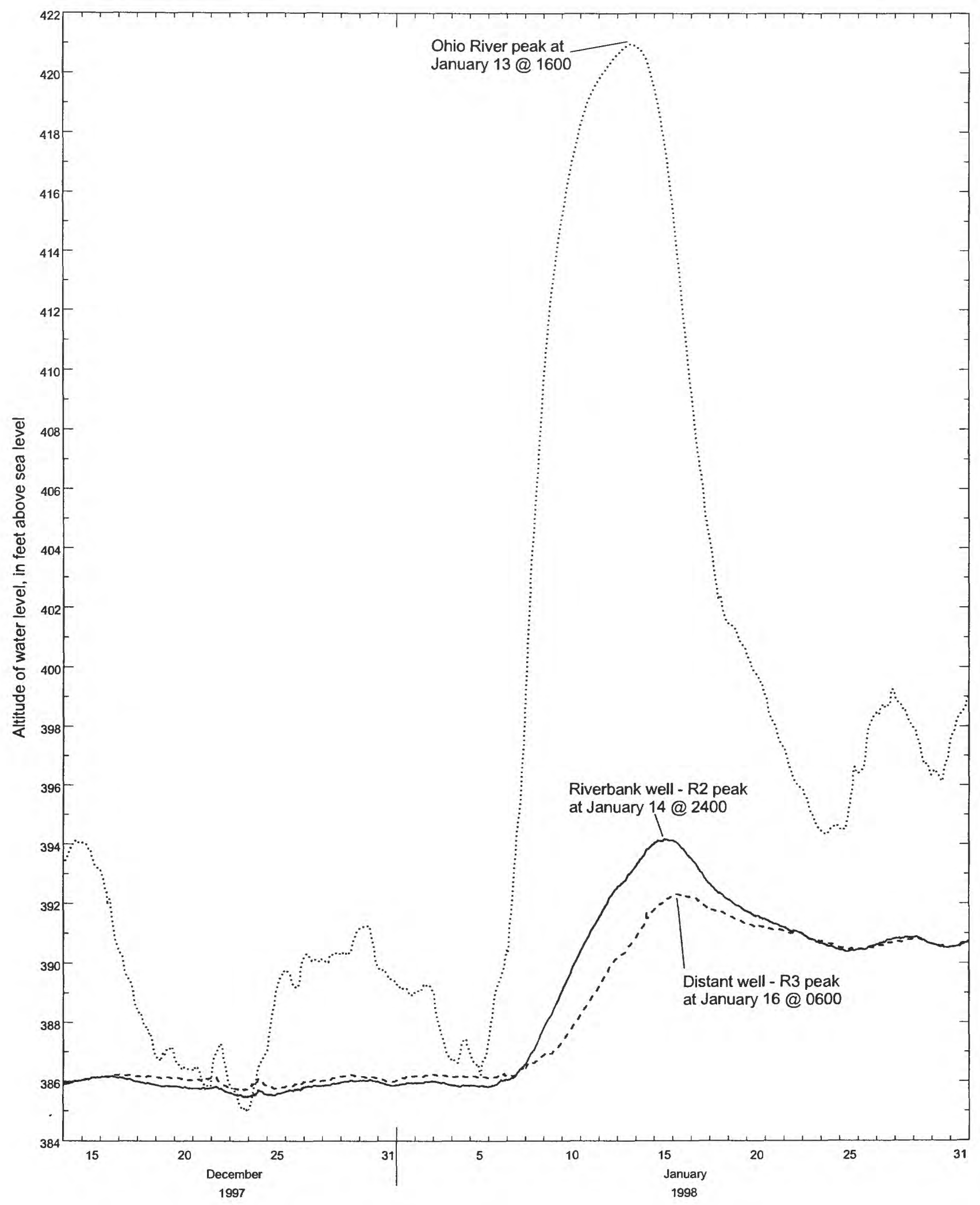

Figure 23a. Response of ground-water levels to January 13,1998, floodpulse on the Ohio River. 


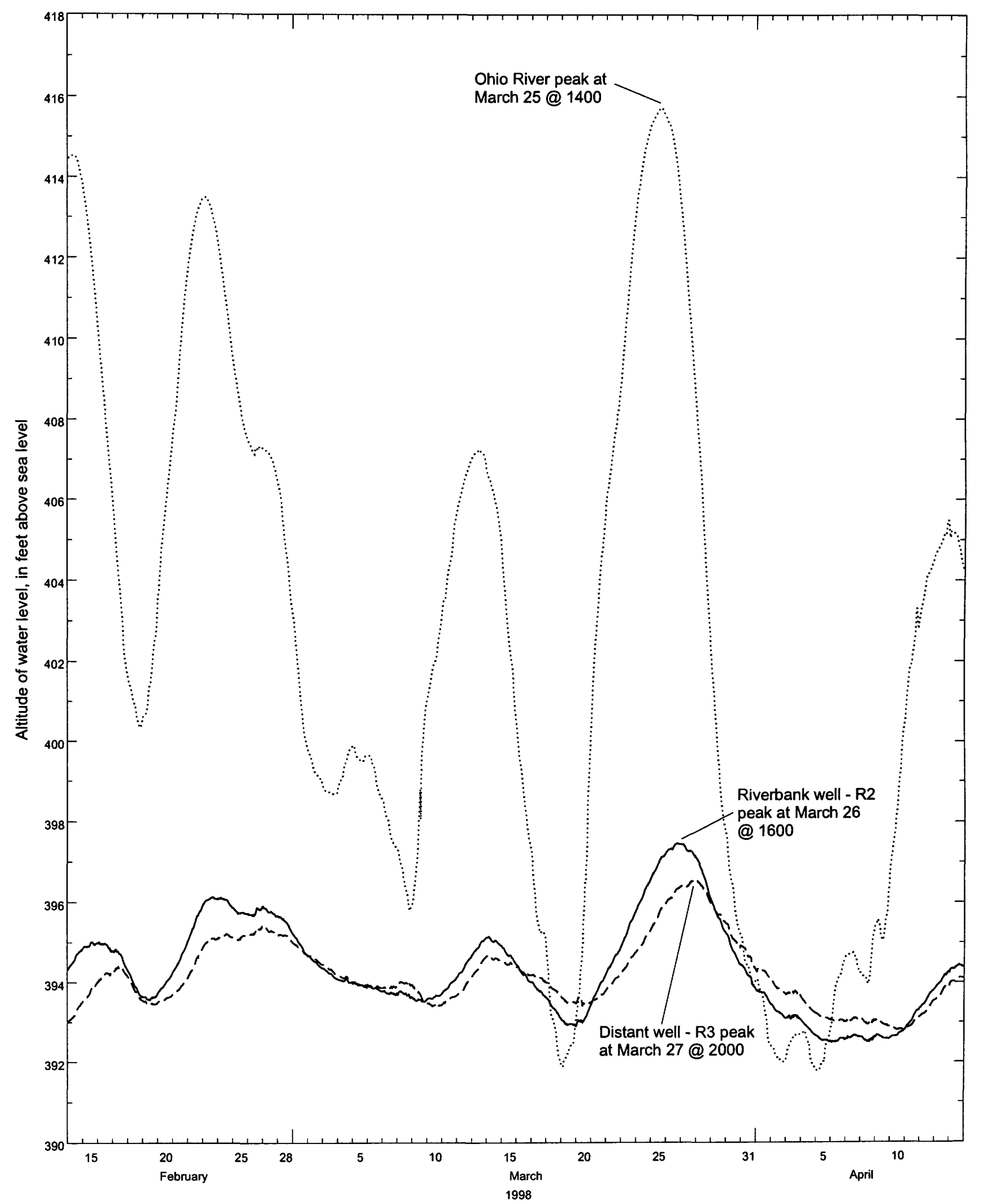

Figure 23b. Response of ground-water levels to March 25, 1998, floodpulse on the Ohio River. 
stream discharges indicates that neither stream interacts significantly with the ground-water-flow system. A summary of the seepage runs is presented in figures $24 \mathrm{a}$ and $24 \mathrm{~b}$ and table 4.

Bee Branch is an intermittent stream and not considered to be an integral component of the groundwater-flow system.

\section{CONCEPTUAL MODEL OF THE GROUND- WATER FLOW SYSTEM}

A preliminary step in designing a numerical model of ground-water flow is to formulate a conceptual model of the flow system. The conceptual model is a simplified representation of the important hydrogeologic conditions of the natural flow system. Field-based data such as aquifer characteristics, ground-water levels, and infiltration rates are measured or estimated to provide a clear and easily understood physical picture of the flow system. Errors in the development of the conceptual model can result in the failure of the numerical model to make accurate predictions.

The hydrogeologic framework of the study area has been divided into three layers (fig. 24). Layer 1 (or the top layer) represents the fine-grained deposits of clay, silt, and fine sand. Layer 1 has an average thickness of $30-40 \mathrm{ft}$ and is present throughout the study area. Layer 2 represents the coarse-grained deposits of sand and gravel; it is referred to in this report as the alluvial aquifer. Layer 3 represents the bedrock. The bedrock shales are usually considered "tight" (very low permeability) and are assumed to form a no-flow boundary in model designs, but water levels from recorder well 9 (fig. 13) show a probable interaction between the bedrock and the alluvial aquifer. The Ohio River is assumed to partially penetrate layer 1 and may be in direct contact with layer 2-the alluvial aquifer-through its course in the study area.

The flow system receives recharge from a number of sources. Precipitation is applied to the top of layer 1 with a positive contributing flow to layer 2 . A direct estimate of this precipitation infiltration, based on calculations by Rorabaugh (1956), could be applied directly to layer 2, thus negating the need for layer 1 ; however, ground-water levels have indicated that the water table might extend upward into the fine-grained deposits under certain conditions, such as during extended periods of high water on the Ohio River. Therefore, layer 1 is included in this conceptualization for thoroughness and possible future applications and refinements in model design.

Additional sources of recharge include flow from the valley wall, induced infiltration from the river, and possible upward flow from the bedrock. Ground-water levels indicate flow from the valley wall toward the river in the study area. Part of the precipitation falling on bedrock upland areas outside of the basin seeps downward into the rock and discharges to the sands and gravels along the contacts of the valley wall. To a much lesser extent, layer 2 receives recharge from induced infiltration of river water in the areas of ground-water withdrawal along the riverbank and from floodwaters during periods of high river stage. Lastly, layer 2 may receive recharge from upward flow from the bedrock (layer 3). Normally, layer 3 would not be included in a model design of the Ohio River alluvial aquifer, but the unique conditions presented by the operation of the gasstorage field make it an integral part of the model design, even if its role is not fully understood at this time.

The Ohio River is the dominant discharge boundary of the flow system. Additionally, exact discharge amounts from the pumped wells are known, and an unknown amount of water may be discharging from the alluvial aquifer to the bedrock, with the ultimate discharge point being the limestones below the shale deposits.

Steady-state conditions were assumed to exist during the November 1997 synoptic water-level measurements. The Ohio River was at or near normal pool stage for an extended period, withdrawals from area wells were well-documented, and, on the basis of water-level hydrographs for November 1997, conditions existed for the alluvial aquifer to be discharging part of its water to the underlying bedrock.

\section{SIMULATION OF GROUND-WATER FLOW IN THE ALLUVIAL AQUIFER}

A finite-difference numerical model was used to simulate ground-water flow in the alluvial aquifer near West Point. The objectives of the modeling were to test the conceptual model of the flow system, generate the required data sets for particle-tracking analysis, and provide a regional-scale tool for water-resources investigations. The modular, finite-difference computer program-MODFLOW (McDonald and Harbaugh, 1988) - was used to construct a regional, quasi- threedimensional, steady-state model of the flow system in 


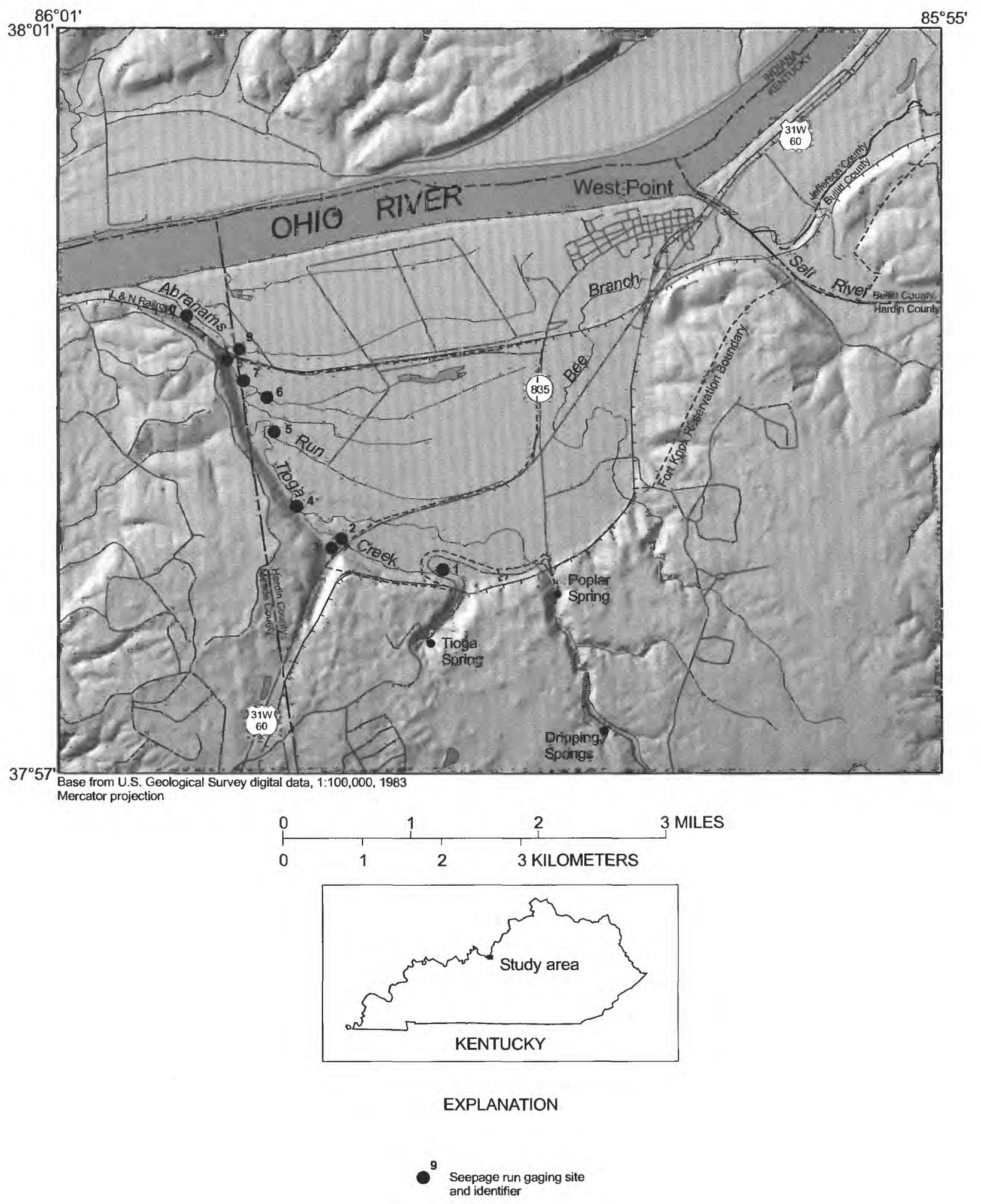

Figure 24a. Location of gaging sites for seepage run \#1, September 18-20, 1996. 


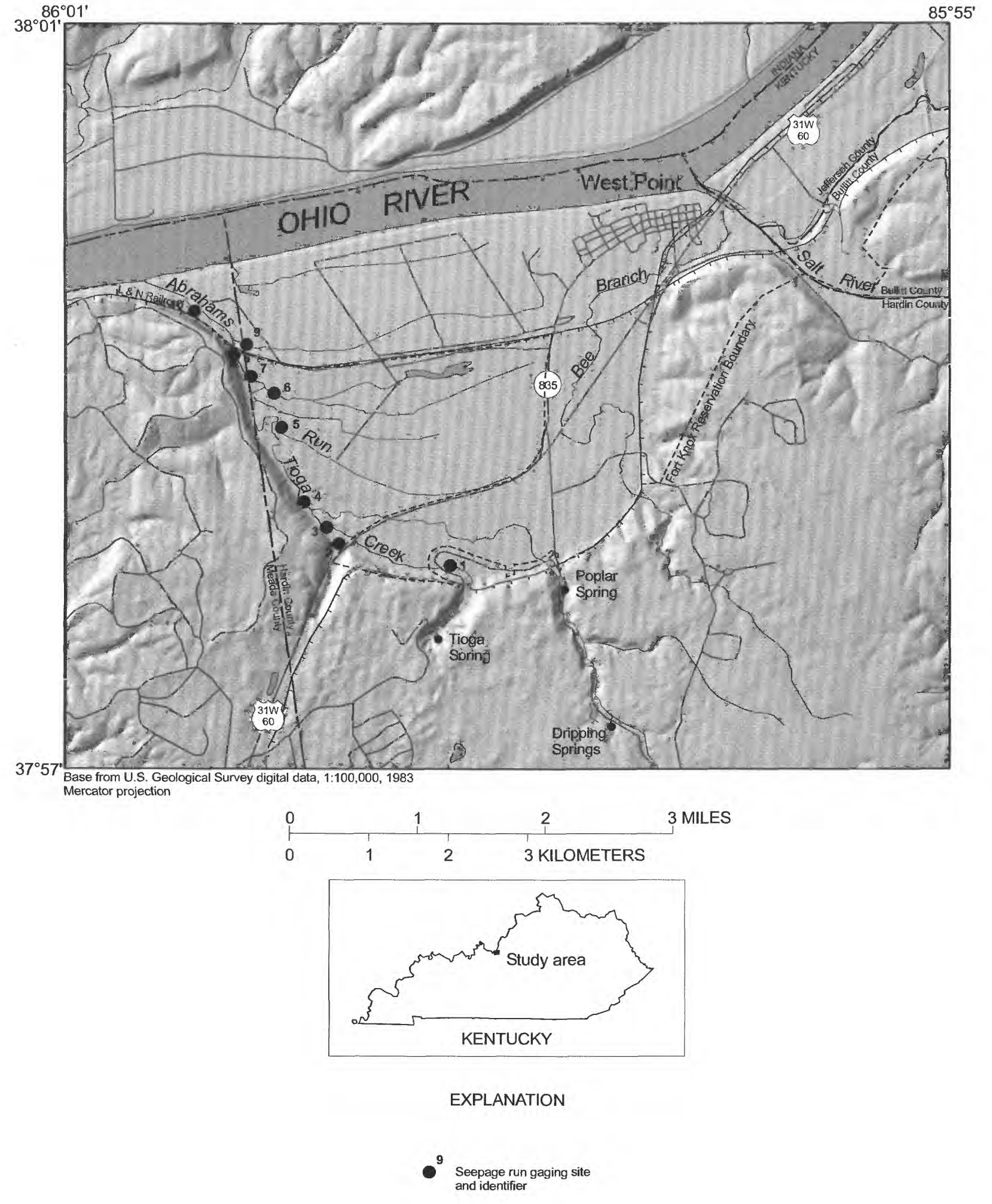

Figure 24b. Location of gaging sites for seepage run \#2, July 18, 1997. 
Table 4. Seepage run results for Abrahams Run, Tioga Creek, and their tributaries [f $\mathrm{ft}^{3} / \mathrm{s}$, cubic foot per second]

\begin{tabular}{|c|c|c|c|}
\hline Site & Date & $\begin{array}{l}\text { Discharge } \\
\left(\mathrm{ft}^{3} / \mathrm{s}\right)\end{array}$ & Remarks \\
\hline \multicolumn{4}{|r|}{ Seepage run number 1, September 18-20, 1996} \\
\hline 1 & $9 / 18 / 96$ & 0.087 & Flow from Tioga Spring \\
\hline 2 & $9 / 18 / 96$ & .60 & $\begin{array}{l}\text { Net gain from sites } 1 \text { and } 2 \text { is } 0.513 \mathrm{ft}^{3} / \mathrm{s} \text {. Site } 2 \text { is just above unnamed feeder } \\
\text { stream from Muldraugh Hill drainage. }\end{array}$ \\
\hline 3 & $9 / 18 / 96$ & .484 & Muldraugh Hill drainage \\
\hline 4 & $9 / 18 / 96$ & 1.12 & Main stem of Tioga Creek below a small unnamed creek, entering from the east. \\
\hline 5 & $9 / 18 / 96$ & .0001 & Abrahams Run, upstream from Tioga Creek \\
\hline 6 & $9 / 18 / 96$ & No flow & Unnamed creek that flows into Abrahams Run; streambed was wet. \\
\hline 7 & $9 / 18 / 96$ & 1.28 & $\begin{array}{l}\text { Cumulative discharge from sites } 1 \text { to } 6 \text { is } 1.1201 \mathrm{ft}^{3} / \mathrm{s} \text {, a gain of } 0.16 \mathrm{ft}^{3} / \mathrm{s} \text {, possibly } \\
\text { from stored moisture in the streambed. }\end{array}$ \\
\hline 8 & $9 / 20 / 96$ & .913 & $\begin{array}{l}\text { Streambed at this site is characterized by thick mud and clays with apparent high } \\
\text { moisture-storage content. Loss of flow is assumed because of storage. }\end{array}$ \\
\hline 9 & $9 / 20 / 96$ & .077 & Unnamed drainage feeding Abrahams Run from the east. \\
\hline 10 & $9 / 20 / 96$ & .932 & $\begin{array}{l}\text { Cumulative discharge for sites } 8 \text { and } 9 \text { is } 0.990 \mathrm{ft}^{3} / \mathrm{s} \text {, a loss of } 0.058 \mathrm{ft}^{3} / \mathrm{s} \text {. Loss is } \\
\text { assumed because of storage. }\end{array}$ \\
\hline \multicolumn{4}{|r|}{ Seepage run number 2, July 18, 1997} \\
\hline 1 & $7 / 18 / 97$ & Dry & Flow from Tioga Spring \\
\hline 2 & $7 / 18 / 97$ & .418 & $\begin{array}{l}\text { Drainage from Muldraugh Hill. This site is the same as site } 3 \text { in Seepage run } \\
\text { number } 1 .\end{array}$ \\
\hline 3 & $7 / 18 / 97$ & .707 & $\begin{array}{l}\text { Net gain of } 0.289 \mathrm{ft}^{3} / \mathrm{s} \text { between sites } 1 \text { and } 3 \text {. This location was not measured } \\
\text { during Seepage run number } 1 \text {. }\end{array}$ \\
\hline 4 & $7 / 18 / 97$ & No flow & Streambed is wet indicating some storage potential. \\
\hline 5 & $7 / 18 / 97$ & Dry & Abrahams Run, upstream from Tioga Creek. \\
\hline 6 & $7 / 18 / 97$ & No flow & Wet streambed \\
\hline 7 & $7 / 18 / 97$ & .784 & $\begin{array}{l}\text { Cumulative discharge of } 0.701 \mathrm{ft}^{3} / \mathrm{s} \text {, net gain of } 0.083 \mathrm{ft}^{3} / \mathrm{s} \text {, possibly from a release } \\
\text { of stored moisture in the streambed. }\end{array}$ \\
\hline 8 & $7 / 18 / 97$ & .444 & $\begin{array}{l}\text { Loss of } 0.34 \mathrm{ft}^{3} / \mathrm{s} \text { assumed because of storage of thick mud and clays in the } \\
\text { streambed. }\end{array}$ \\
\hline 9 & $7 / 18 / 97$ & No flow & None \\
\hline 10 & $7 / 18 / 97$ & .427 & $\begin{array}{l}\text { Additional loss of } 0.017 \mathrm{ft}^{3} / \mathrm{s} \text { from site } 8 \text {. Loss assumed because of storage of } \\
\text { streambed. }\end{array}$ \\
\hline
\end{tabular}


the alluvial aquifer. The model code uses finite-difference formulations and an iterative algorithm (Strongly Implicit Procedure for this application) to solve the ground-water-flow equations at discrete and regularly arranged points. The solution is only an approximation because of three factors: most of the input data are estimated spatially and quantitatively within an acceptable range of hydrologically reasonable values based on measured data; the formulations are solved discretely rather than continuously; and the solution method is iterative and computations are stopped once a predetermined error tolerance of the difference between observed water levels and simulated water levels is met. Output from the MODFLOW program is used by the particle-tracking program-MODPATH (Pollock, $1989,1994)$ - to simulate ground-water-flow paths and travel times. The combination of the MODFLOW simulation and the application of the results through the MODPATH program provides an investigative tool for area water-resources managers.

\section{Equation Development}

The ground-water-flow model is formed from a set of partial differential equations: a governing equation and equations that define boundary conditions and initial conditions. Numerical methods are used to solve a set of algebraic equations generated by approximating these equations. A general form of the partial differential equation governing steady-state flow of ground water (assumed to have constant density) in a heterogeneous, isotropic, unconfined aquifer is:

$$
\frac{\partial}{\partial_{x}}\left(-K_{x} \frac{\partial_{h}}{\partial_{x}}\right)+\frac{\partial}{\partial_{y}}\left(-K_{y} \frac{\partial_{h}}{\partial_{y}}\right)+\frac{\partial}{\partial_{z}}\left(-K_{z} \frac{\partial_{h}}{\partial_{z}}\right)=0,
$$

where

$x, y$, and $z$ are the three directional variables;

$K_{x} K_{y}$ and $K_{z}$ are the hydraulic conductivities of the aquifer in the $x, y$, and $z$ directions; and

$h$ is the hydraulic head in the aquifer at the point for which the equation is being solved.

Boundary conditions and initial conditions were selected to represent the hydraulic conditions assumed in the conceptual model. The governing equation and the equations defining boundary conditions and initial conditions were combined in a set of finite-difference equations and solved numerically using the MODFLOW code.

\section{Model Assumptions}

The ground-water-flow model was designed in accordance with the following assumptions and simplifications:

1. Ground-water levels during fall 1997 approximate average water levels for the modeled area during periods of the least amount of changing hydrologic stresses. The ground-water-flow system is considered at steady state during this period, meaning no net gain or loss of water occurs.

2. All simulated wells fully penetrate the alluvial deposits.

3. Infiltration from precipitation is at a constant rate and does not vary areally.

4. The Ohio River is hydraulically connected to the alluvial aquifer throughout its course in the study area.

5. The shales below the alluvial deposits may contribute water to the flow system in the alluvial deposits.

6. Vertical hydraulic conductivity for each model layer is uniform.

\section{Model Grid and Layers}

The model was discretized vertically into three layers (fig. 25). Model layer 1 represents the fine-grained deposits of clay, silt, and fine sand in the study area. Model layer 2 represents the coarse-grained alluvial deposits in which all of the public water-supply wells are screened. Model layer 3 represents the upper part of the bedrock (shales) in the study area.

The grid design used to represent the conceptual model of the ground-water-flow system is shown in figure 26 . The grid comprises 40 rows and 48 columns simulating an area of 22,800 by $27,360 \mathrm{ft}$, respectively, or approximately $22.4 \mathrm{mi}^{2}$; grid cells are $570 \mathrm{ft}^{2}$. The grid rows are oriented parallel to the reach of the Ohio River within the study area and perpendicular to the regional ground-water-flow direction as indicated in the conceptual model. 


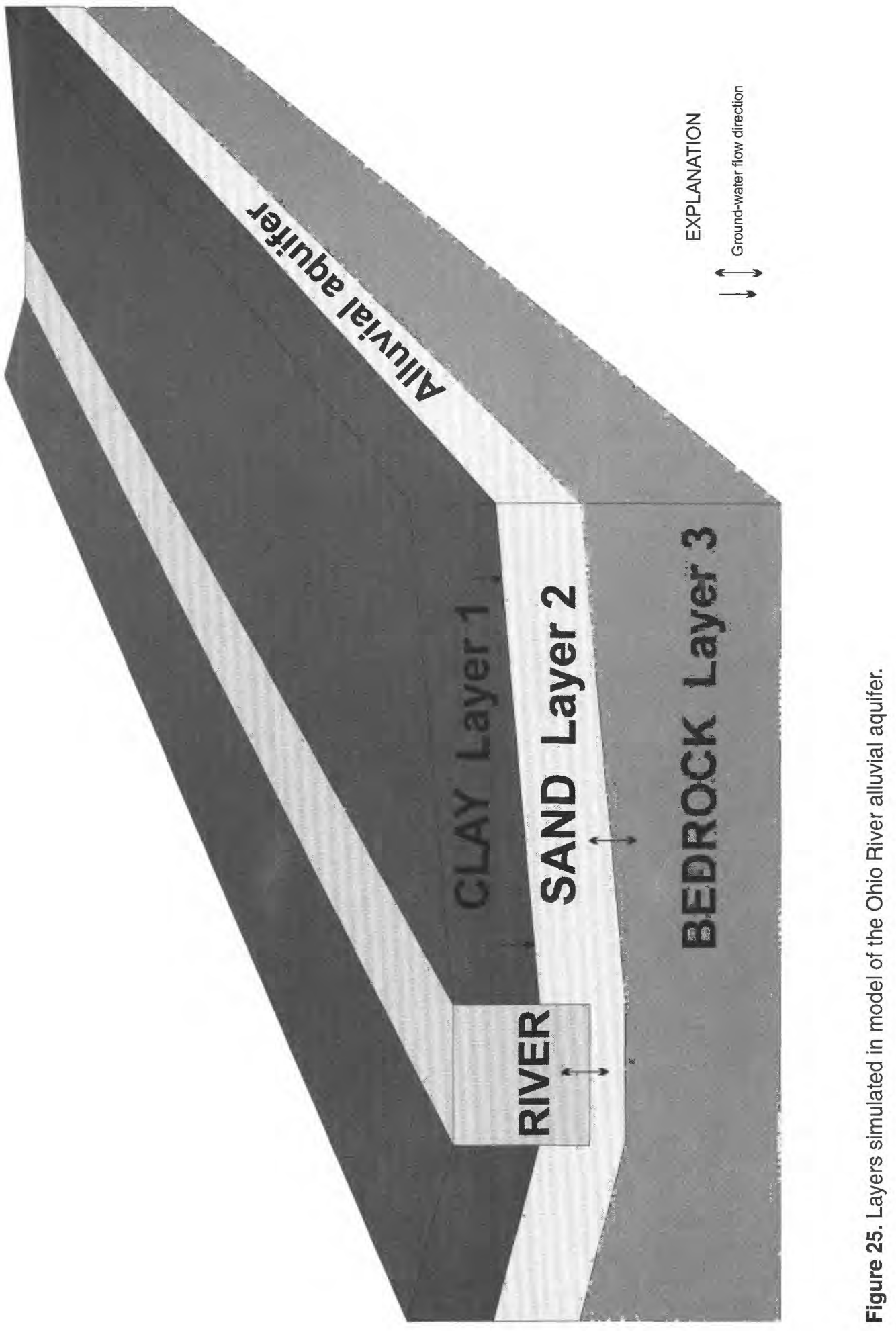




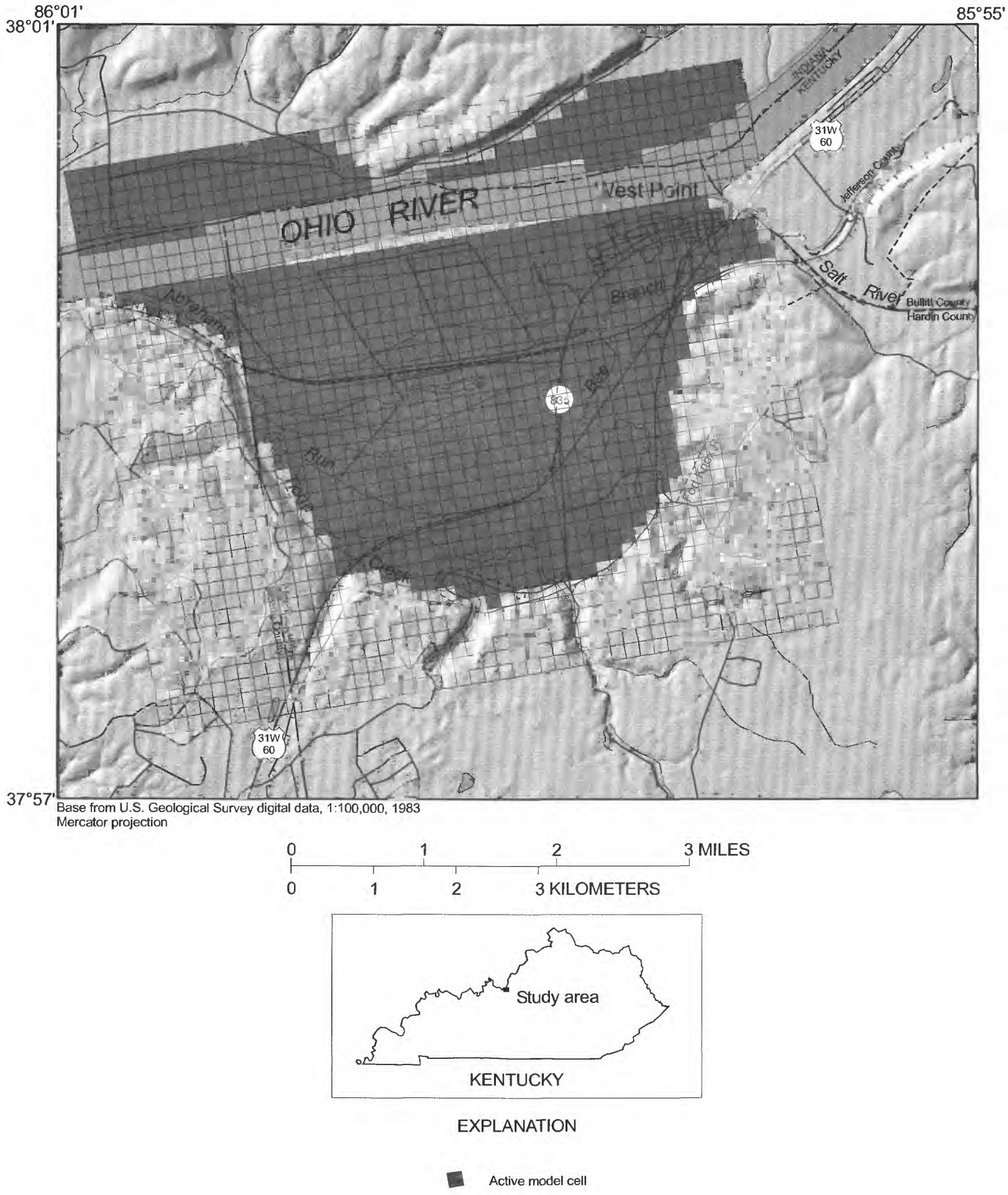

Figure 26. Extent of the model grid. 


\section{Model Boundaries}

Gallaher and Price (1966) refer to the Ohio River Valley as a huge water container. In the area of West Point, this "container" was probably formed by a cut-off meander of the Ohio River. The valley has been cut down into the bedrock and partly filled with waterdeposited sediments. The valley walls are natural hydrologic boundaries that form most of the lateral boundaries of the modeled area. The valley walls contribute water to the flow system within the valley and are modeled as general head boundaries. Flow across general head boundaries depends upon the difference in head between an active model cell and an adjacent external source. For this investigation, an external head of $500 \mathrm{ft}$ was assumed because observation points (wells) outside of the basin on the upland areas were not available. Flow contributions from the valley walls were calculated using the Darcy equation and an estimated value of hydraulic conductivity $(10 \mathrm{ft} / \mathrm{d})$ for the bedrock formations.

The Ohio River was modeled by use of the river package of the MODFLOW code. The altitude of the river stage was $383 \mathrm{ft}$, which is the normal pool stage. Stage data were collected at the USGS gaging station on the lower pool of the Ohio River at the McAlpine Locks and Dam, Louisville, Ky., approximately $12 \mathrm{mi}$ upstream from West Point.

The remaining lateral boundaries near the Ohio River were modeled as head-dependent boundaries. The potentiometric-surface map of the ground water for November 1997 was used to determine gradients in head and flow direction across the boundaries. Values of hydraulic conductivity for aquifer material outside of the modeled area were assigned the same hydraulic conductivity as the adjacent cell.

Precipitation infiltration forms a specified flux boundary for the top layer of the model and is simulated with the recharge package of the MODFLOW code.

\section{Input Parameters}

Initial input parameters for the ground-water-flow model were derived from reviews of previous studies, records from area ground-water users, and from data collected as part of this investigation. Input parameters included the thickness of the fine- and coarse-grained deposits; the elevation of the bedrock surface; recharge from precipitation; Ohio River characteristics such as stage, river-bottom elevation, riverbed thickness, and riverbed conductance; hydraulic conductivity of the alluvial deposits; boundary conditions of the bedrock and valley walls; and initial ground-water levels and reported pumpage. Selected input parameters were systematically varied over respective ranges of acceptable values until simulated water levels for the alluvial aquifer approximated the water levels from the November 1997 synoptic measurement.

Thickness of the fine- and coarse-grained deposits and the elevation of the bedrock surface were estimated from information in historical drillers' logs and the logs of wells drilled as part of this investigation. Thiessen polygons were delineated based on available point data to populate the model data sets. Figures 27-29 show the approximations developed for elevation of land surface (top of layer 1), elevation of fine/coarse-grained sediments (top of layer 2), and elevation of the bedrock surface (bottom of layer 2). Thiessen or proximal polygons are used to apportion a point data set into regions where each region has the unique property of its particular data point.

Recharge from precipitation was applied to the top of layer 1. The annual precipitation for 1997 for the Louisville metropolitan area, which includes the study area, was $49.66 \mathrm{in}$. The recharge was distributed evenly throughout the model area for the simulation.

The elevation of the Ohio River stage was simulated at $383 \mathrm{ft}$ on the basis of data from the USGS gaging station at the McAlpine Locks and Dam. Riverbed elevation was held constant at $360 \mathrm{ft}$.

The hydraulic conductivity of the alluvial deposits in layer 2 was assigned on the basis of results from slug tests conducted as part of this investigation. Figure 30 shows the location and average calculated hydraulic conductivity value for each control point (test well) and the Thiessen polygon approximations.

The valley walls, which form boundaries for the ground-water-flow system, were simulated as headdependent boundaries. An external boundary head elevation of $500 \mathrm{ft}$ and a hydraulic conductivity value of $10 \mathrm{ft} / \mathrm{d}$ were assumed for each cell of the boundary.

Other input parameters used for the simulation (but not varied) included the water-table elevation for November 1997, vertical hydraulic conductivity values for layers 1 and 3, head in layer 3 (390 ft), and the reported withdrawals from the area's well fields. Ground-water pumpage was simulated for Hardin County Water District No. 1, West Point Municipal Water Works, and the Fort Knox well fields; locations 


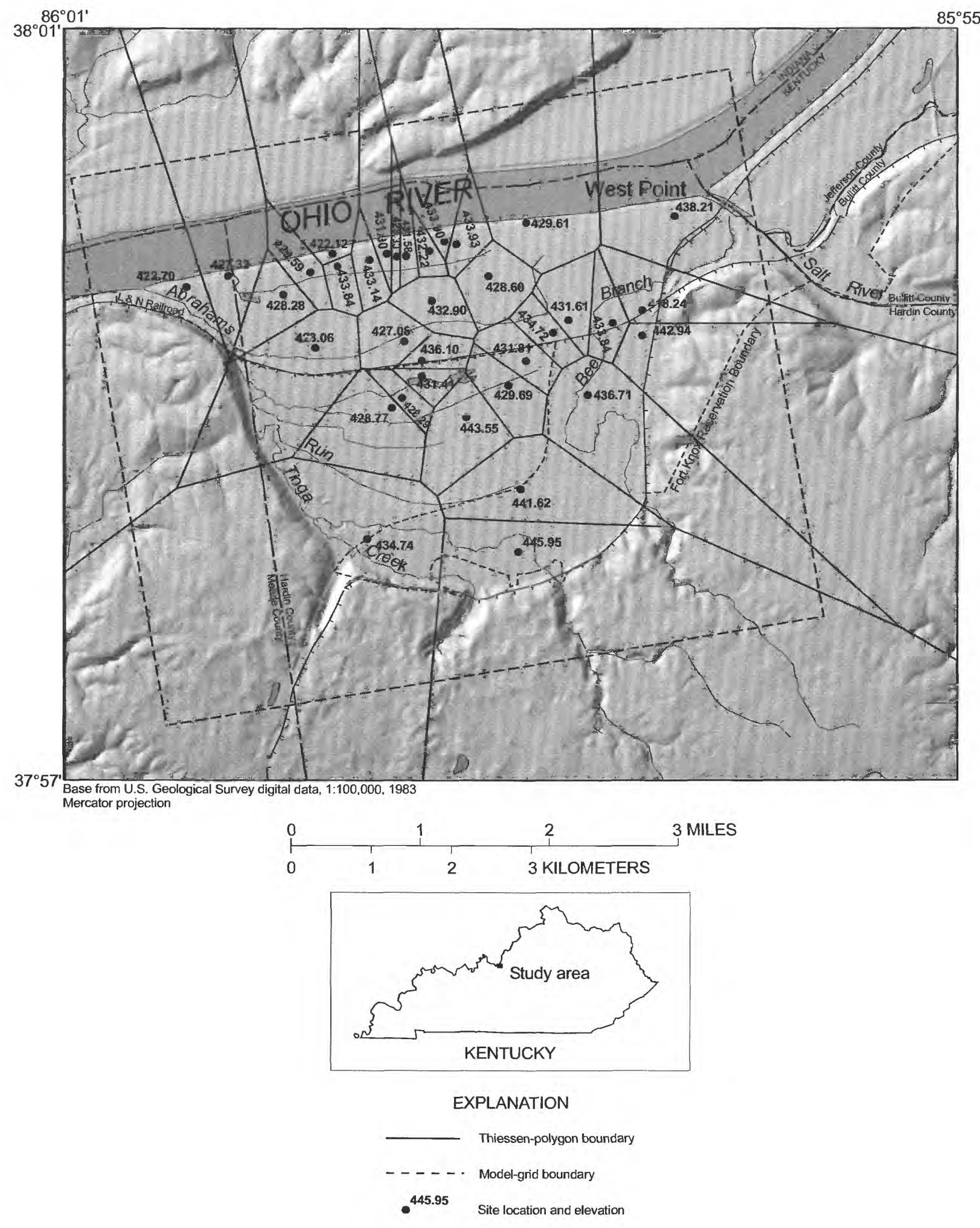

Figure 27. Thiessen polygons for land-surface elevation (layer 1). 


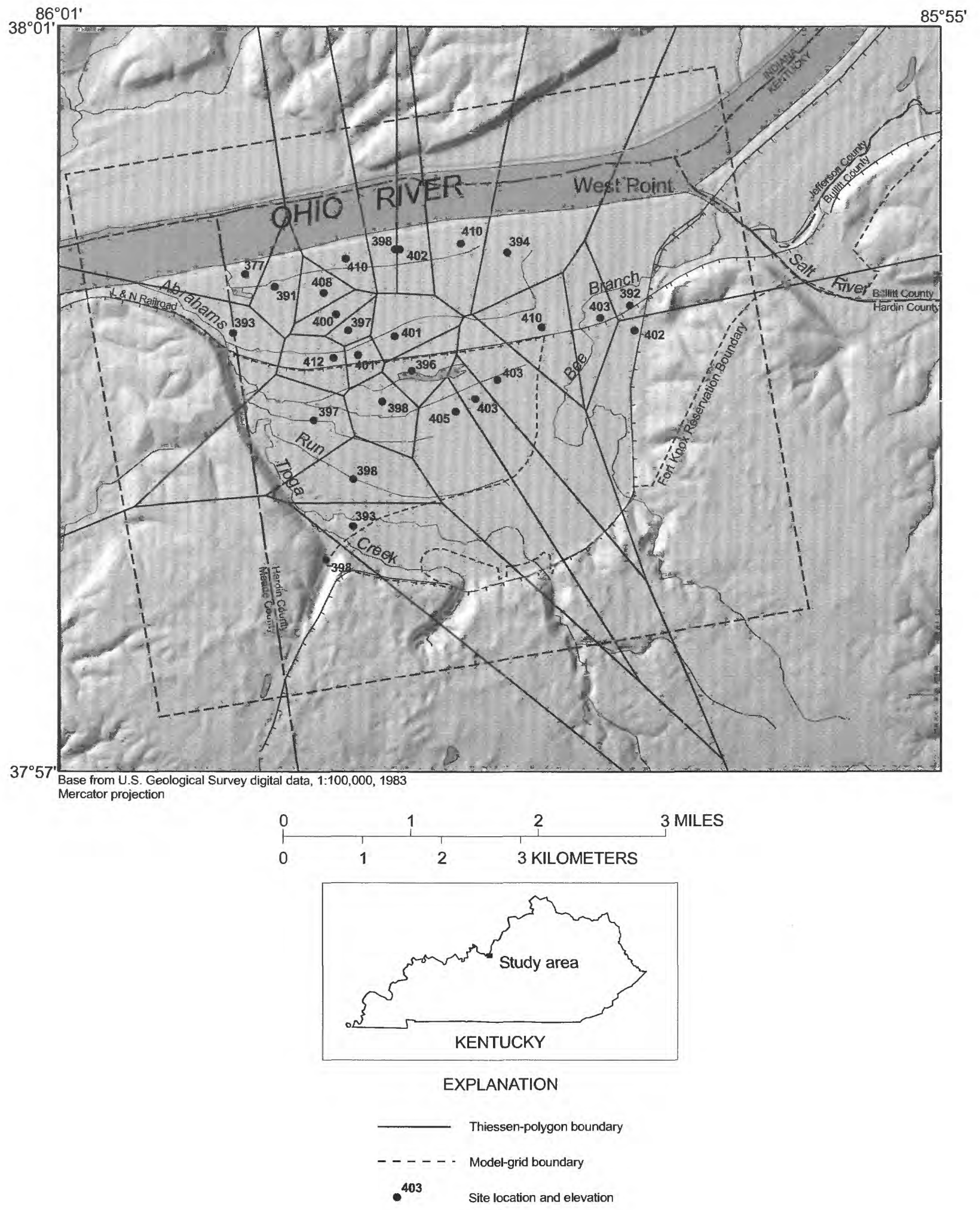

Figure 28. Thiessen polygons for elevation of fine-grained/coarse-grained deposits interface (layer 2). 


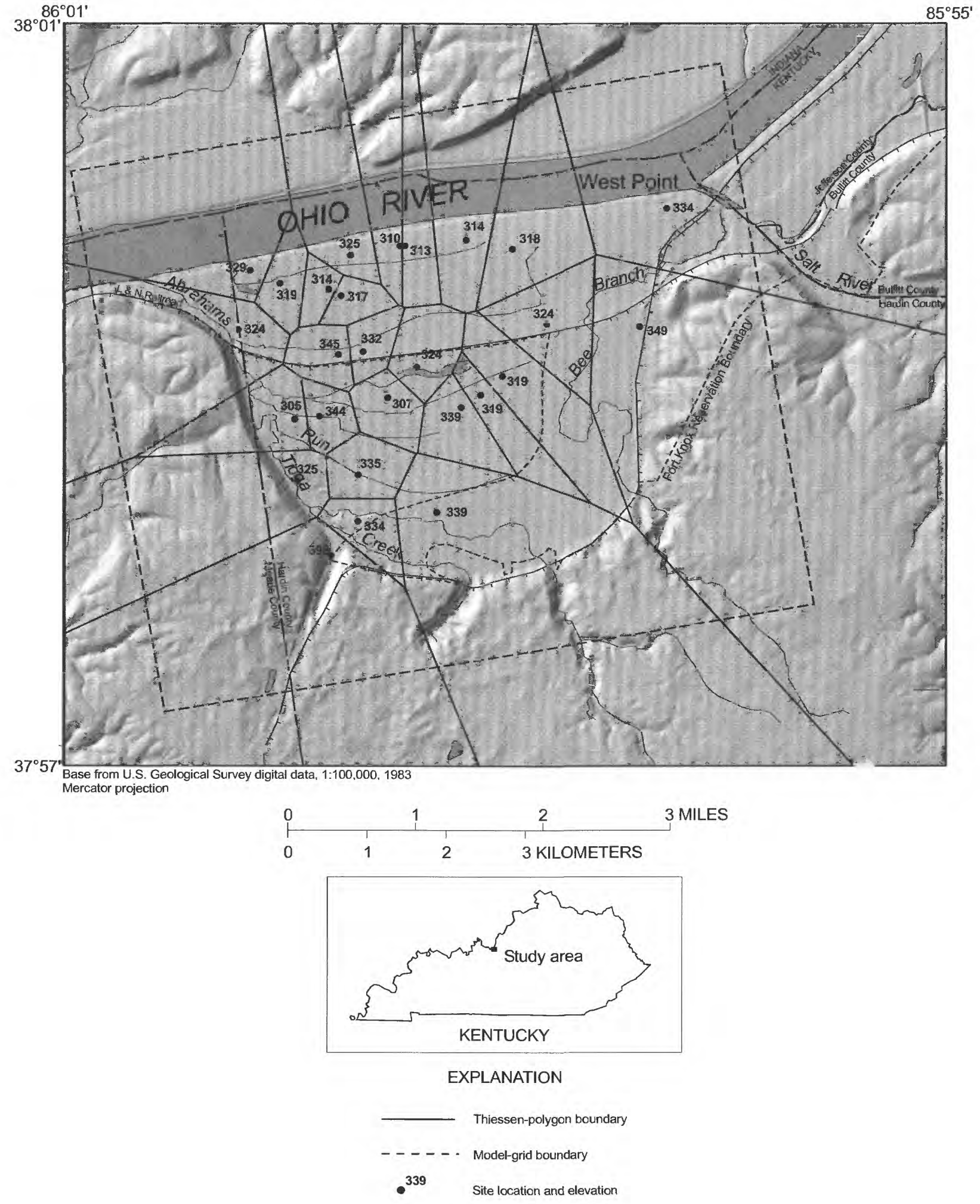

Figure 29. Thiessen polygons for bedrock elevations (bottom of layer 2). 


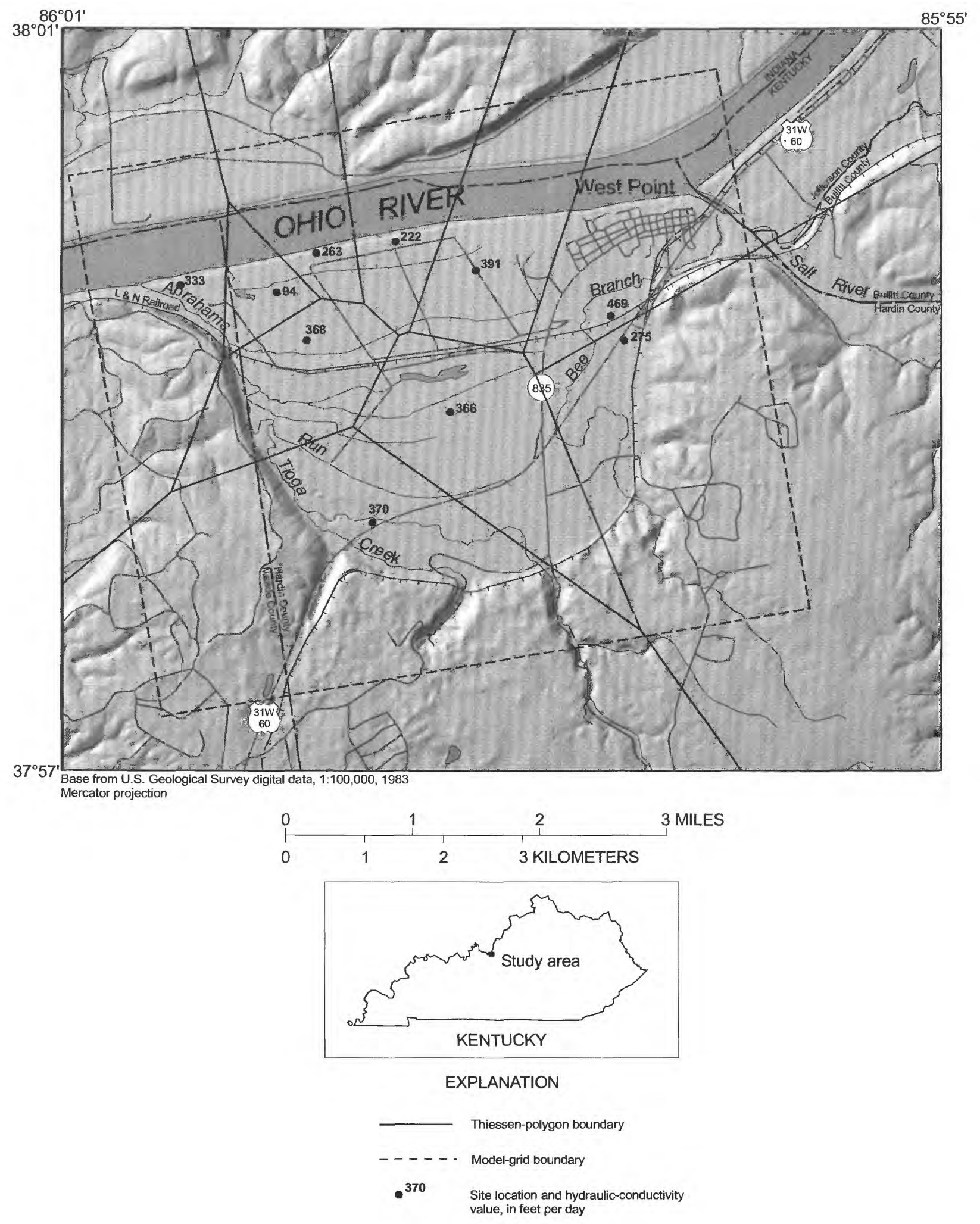

Figure 30. Thiessen polygons for hydraulic-conductivity values of layer 2 . 
and pumpage amounts were verified for November 1997.

\section{Steady-State Calibration and Water Budget}

Calibration of a model is a procedure in which initial input parameters are adjusted (within a reasonable range) until the difference between simulated and observed heads (water levels) is reduced to an acceptable range. For this simulation, a number of input parameters were adjusted to meet the predetermined calibration criteria: recharge from precipitation, vertical conductance for model layer 1 , vertical conductance and hydraulic conductivity values for model layer 2 , conductance values for general head-boundary configurations, and riverbed conductance values.

The root-mean-square-error (RMSE) of the measured and simulated heads was used to determine the effect of an adjustment. The RMSE is calculated by the equation:

$$
R M S E=\sqrt{\sum_{i=1}^{N} \frac{\left(h_{s i m i}-h_{m i}\right)^{2}}{N}},
$$

where

$$
\begin{aligned}
& h_{s i m i} \text { is the simulated head; } \\
& h_{m i} \text { is the measured head; and } \\
& \mathrm{N} \text { is the number of measurements used in } \\
& \text { error computations. }
\end{aligned}
$$

Decreases in the RMSE indicate an improvement in the overall fit of the simulation to the observed conditions.

The calibration criteria were based on an observed range of ground-water levels assuming steady-state conditions. The steady-state simulation of the alluvial aquifer near West Point represents a period during which the flow system in the aquifer was in equilibrium, meaning there were no changes in storage. Actual steady-state conditions probably never existed for the aquifer because of continuous, small changes in recharge (river stage, precipitation, and flow from the valley wall) and discharge (river stage and groundwater withdrawals). However, synoptic measurements of ground-water levels, continuous records of groundwater levels, and hydrographs of Ohio River stage indicate the alluvial aquifer was generally at or near steadystate conditions during September through December 1997. For purposes of this investigation, it was assumed that the aquifer was at steady state during this period, and the ground-water-flow conditions, as measured in November 1997, were chosen as the target levels for calibration of the model.

The calibration criteria were dependent upon ground-water levels measured in 32 wells during 2 synoptic measurements (September and November 1997). Based on these measurements, the calibration criteria selected were a maximum difference of $7.59 \mathrm{ft}$ with an average difference of $1.77 \mathrm{ft}$ between simulated and observed water levels for November 1997.

The steady-state model of the alluvial aquifer was calibrated to a maximum difference of $5.80 \mathrm{ft}$ between simulated and observed water levels for November 1997. The simulated and observed water levels differed by less than $3 \mathrm{ft}$ in 91 percent of the wells, less than $2 \mathrm{ft}$ in 78 percent, and less than $1 \mathrm{ft}$ in 53 percent of the wells. The average difference in water levels for the 32 wells was $1.34 \mathrm{ft}$; the RMSE for the calibrated simulation was 1.88 . Figure 31 shows the difference between observed and simulated heads for the model calibration.

In addition to the simulated heads, the calibrated model provided a simulated ground-water budget for the aquifer under steady-state conditions. The simulation indicated that, of the total recharge to the alluvial aquifer, 50 percent came from infiltration of precipitation, 49 percent came from lateral flow from the valley wall, and induced infiltration from the Ohio River accounted for 1 percent. Ground-water flow to the Ohio River accounted for 68 percent of the system discharges, 28 percent discharges to ground-water withdrawal wells, and 4 percent discharges to the shale below the alluvial deposits.

\section{Sensitivity Analysis}

Sensitivity analysis is a procedure to assess how the calibrated model responds to systematic changes in each selected input parameter. The analysis determines which parameters exert the most control over the model output (water levels or heads) and possibly generate the largest error when the parameter is incorrectly estimated or miscalculated. Parameters that were varied in the sensitivity analysis include hydraulic conductivity, precipitation, river stage, and terms associated with general head boundaries. Each input parameter was varied a specified amount from the calibrated value used in the steady-state simulation. The amount of variance was determined by estimates of the probable range of data. 


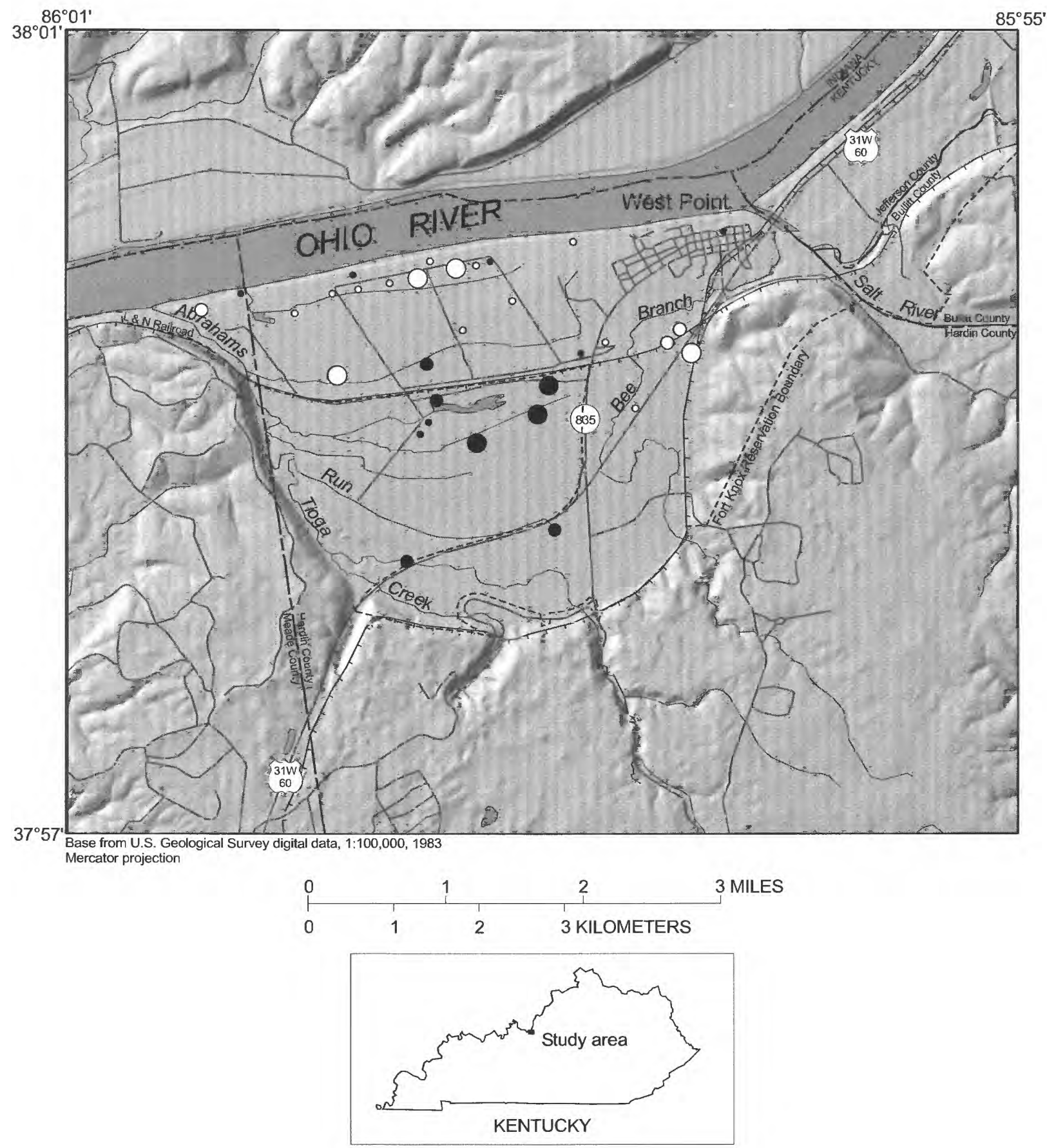

EXPLANATION

Observed - modeled

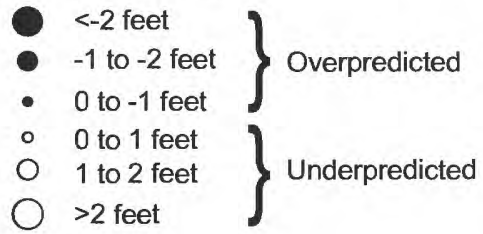

Figure 31. Observed versus modeled water levels for steady-state simulation. 
Because each change in parameter value was tested separately, the additive effects of changes for different combinations of parameter values were not considered.

Model sensitivity was described in terms of the root RMSE using the differences between the observed and modeled ground-water levels for the observation wells finished in layer 2 of the model. The model was most sensitive to changes in (1) general head-boundary conductance, (2) precipitation, and (3) the hydraulic conductivity values for layer 2 . The model is least sensitive to changes in the vertical conductance for layer 1 , vertical conductance for layer 2 , and riverbed conductance. Table 5 lists the results of the sensitivity analyses.

Table 5. Results of sensitivity analyses of the calibrated flow model of the Ohio River alluvial aquifer near West Point, Kentucky

[RMSE, root mean square error; ---, not applicable]

\begin{tabular}{|c|c|c|c|}
\hline $\begin{array}{l}\text { Parameter } \\
\text { tested }\end{array}$ & $\begin{array}{l}\text { Change in } \\
\text { parameter }\end{array}$ & RMSE & $\begin{array}{c}\text { Difference } \\
\text { between } \\
\text { upper and } \\
\text { lower RMSE }\end{array}$ \\
\hline Calibrated model & $\ldots$ & 1.88 & $\cdots$ \\
\hline $\begin{array}{l}\text { Hydraulic } \\
\text { conductivity } \\
\text { of layer } 1\end{array}$ & $\begin{array}{l}x 2 \\
x .5\end{array}$ & $\begin{array}{l}1.96 \\
1.96\end{array}$ & 0 \\
\hline $\begin{array}{l}\text { Vertical } \\
\text { conductance } \\
\text { of layer } 1\end{array}$ & $\frac{\mathrm{x} 2}{\mathrm{x} .5}$ & $\begin{array}{l}1.96 \\
1.96\end{array}$ & 0 \\
\hline $\begin{array}{l}\text { Hydraulic } \\
\text { conductivity } \\
\text { of layer } 2\end{array}$ & $\begin{array}{l}x 2 \\
x .5\end{array}$ & $\begin{array}{l}4.74 \\
5.92\end{array}$ & -1.18 \\
\hline $\begin{array}{l}\text { Vertical } \\
\text { conductance } \\
\text { of layer } 2\end{array}$ & $\begin{array}{l}x 2 \\
x .5\end{array}$ & $\begin{array}{l}1.98 \\
2.06\end{array}$ & -.08 \\
\hline $\begin{array}{l}\text { Transmissivity } \\
\text { of layer } 3\end{array}$ & $\begin{array}{l}\mathrm{x} 2 \\
\mathrm{x} .5\end{array}$ & $\begin{array}{l}1.98 \\
2.04\end{array}$ & -.06 \\
\hline $\begin{array}{r}\text { Natural recharge } \\
\text { (precipitation) }\end{array}$ & $\begin{array}{l}x 2 \\
x .5\end{array}$ & $\begin{array}{l}5.49 \\
3.55\end{array}$ & +1.95 \\
\hline $\begin{array}{l}\text { General head } \\
\text { boundary } \\
\text { conductance } \\
\text { term }\end{array}$ & $\begin{array}{l}x 2 \\
x .5\end{array}$ & $\begin{array}{l}5.08 \\
3.08\end{array}$ & +2 \\
\hline $\begin{array}{l}\text { Riverbed } \\
\quad \text { conductance }\end{array}$ & $\begin{array}{l}\mathrm{x} 2 \\
\mathrm{x} .5\end{array}$ & $\begin{array}{l}2.03 \\
2.00\end{array}$ & +.03 \\
\hline
\end{tabular}

\section{Limitations of the Model}

The extent and detail of hydrogeologic knowledge of a natural flow system, the initial scale of a groundwater-flow model, and the inherent limitations of numerical models restricts applications of such models. With proper application and understanding of these limitations, however, a numerical model is a viable investi- gative tool capable of simulating regional ground-water flow through alluvial deposits.

Model calibration, boundary conditions, and grid design all are based on hydrogeologic knowledge of the natural flow system. For this assessment of hydrogeologic conditions in the Ohio River alluvial aquifer at West Point, a series of synoptic water-level measurements was made and continuous-recording devices were monitored on eight wells within the study area. Steady-state conditions were assumed for conditions observed in November 1997, and data collected were used for the model calibration. The realization that these conditions probably exist for only 3 months of the year is a major limitation of the current model configuration and limits its application. The changing nature of the ground-water-flow system, emphasized in part by fluctuations in river stage and possible effects of the gasstorage operation, requires consideration of a transient simulation to accurately model the ground-water-flow conditions for the majority of the year.

Boundary conditions, particularly regarding the general-head-boundary design of the valley wall, were based on published data, county/project file data, continuous water-level recordings, and the conceptual model. Additional data are needed to verify or correct the assumed values of head and conductance assigned to the valley-wall boundary. The grid design, based on the anticipated ground-water flow, was formulated by the conceptual model and the spatial distribution of available control points, or observation wells. Hydrogeologic characterization of the natural flow system will improve with the incorporation of additional data.

Scale limitations also should be considered when using the model to predict the response of the groundwater-flow system to changes in applied stresses or to hypothetical scenarios such as travel paths of hazardous-material releases. The response of the groundwater-flow system to large-scale changes, such as a 50 -percent increase in ground-water pumpage or the addition of $1 \mathrm{in}$. of recharge from precipitation infiltration, can be simulated with a limited degree of accuracy. The response of the ground-water-flow system to smallscale changes, such as rearranging ground-water withdrawals in a closely spaced well field, might not be accurately simulated. Estimations of contributing areas to wells, the delineation of flow paths, and the calculation of time of travel for water particles (and contaminants moving with the water) are subject to error. The limitations of particle tracking are directly related to the uncertainty in parameter estimations and incorrect 
model design. Contributing areas to wells are approximated because simplifying assumptions are made in estimating parameters that characterize the alluvial deposits, and by necessity a limited number of particles are used in tracking simulations.

\section{APPLICATION OF THE GROUND-WATER- FLOW MODEL}

The calibrated ground-water-flow model was used to delineate recharge and discharge boundaries and to estimate flow paths and travel times of particles placed in the flow system. The cell-by-cell flow terms from the calibrated steady-state model were used as input to MODPATH, a particle-tracking program (Pollock, 1989 , 1994). The MODPATH program computes particle locations and travel times in three dimensions based on advective flow in a uniformly porous medium. MODPATH can track particles forward in time and space in the direction of ground-water flow or backward toward recharge areas (Robinson and others, 1997).

To delineate discharge areas, one particle, representing an infinitesimal volume of ground water, was placed at the center of all active cells in the model grid. Each particle progressed forward in time and space through the ground-water-flow system until a discharge boundary was encountered. Cells discharging to the same boundary were grouped to produce a map identifying the contributing areas (fig. 32). Discharging boundaries include area ground-water withdrawal wells and the Ohio River. Likewise, particles were placed at the center of all active cells and allowed to progress backward in time and space to recharge boundaries. Recharge boundaries for the model include the valley wall and to a much lesser extent, the Ohio River near the riverbank ground-water withdrawal wells. Assuming an effective porosity of 0.20 (Bell, 1966), typical groundwater velocities ranged from approximately $0.032 \mathrm{ft} / \mathrm{d}$ near the valley wall to $29.65 \mathrm{ft} / \mathrm{d}$ around the groundwater withdrawal wells. The MODPATH simulations/output indicate that the average time of travel of water in the aquifer-from recharge to discharge - is about 1,852 days. Ground-water velocities for particles simulating induced infiltration from the Ohio River averaged about $0.297 \mathrm{ft} / \mathrm{d}$.

To estimate flow paths and travel times for a specific well, particles were placed at the center of the model cell representing a withdrawal well. The particles were traced backward in time and space to delineate the possible contributing area for this particular well.
Figure 33 shows the extent of the modeled contributing area and the calculated times-of-travel contours to the well.

Particle-tracking analysis may be used to estimate travel times for the advective transport of a conservative (non-degrading) chemical constituent or contaminant originating from a potential point source within the study area. For illustrative purposes, particles were placed in the cell representing the abandoned gas well 27, a potential source of chloride contamination (Lyverse and Unthank, 1988). The particles were allowed to migrate forward in time and space, thus illustrating the advective flow paths and chlorides from the bedrock could migrate along (fig. 34 ) in the alluvial deposits. Time-of-travel estimates can then be plotted on the trace of the resulting flow paths to project arrival times at different locations along the flow path. It is assumed that physical, chemical, and biological processes that could alter chemical constituents in ground water are not a factor in this application, and the dissolved contaminant is assumed to not appreciably alter the density of the ground water. 


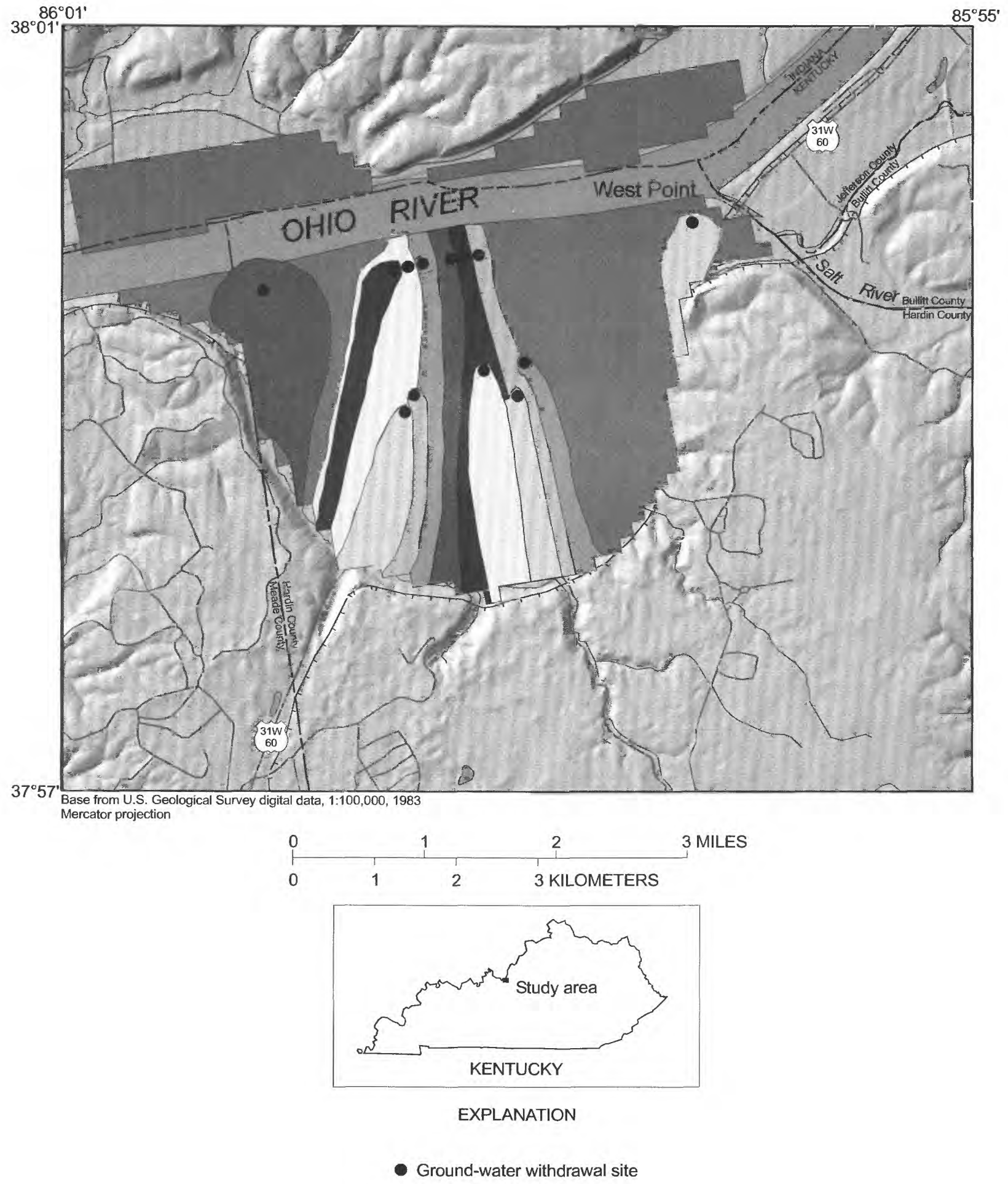

Figure 32. Contributing areas to discharge boundaries. 


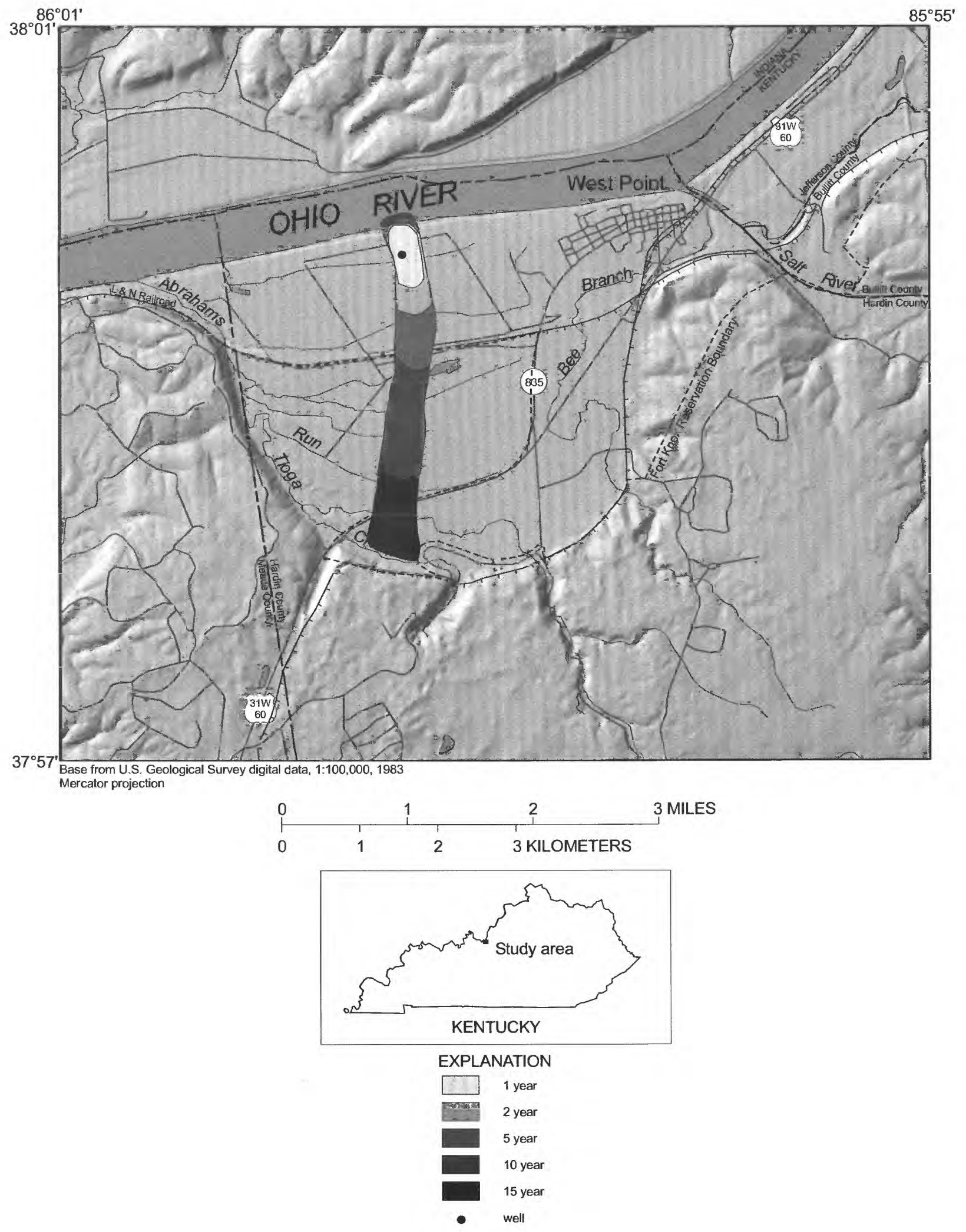

Figure 33. Contributing area and time-of-travel estimates for a Fort Knox public water-supply well screened in the unconsolidated deposits. 


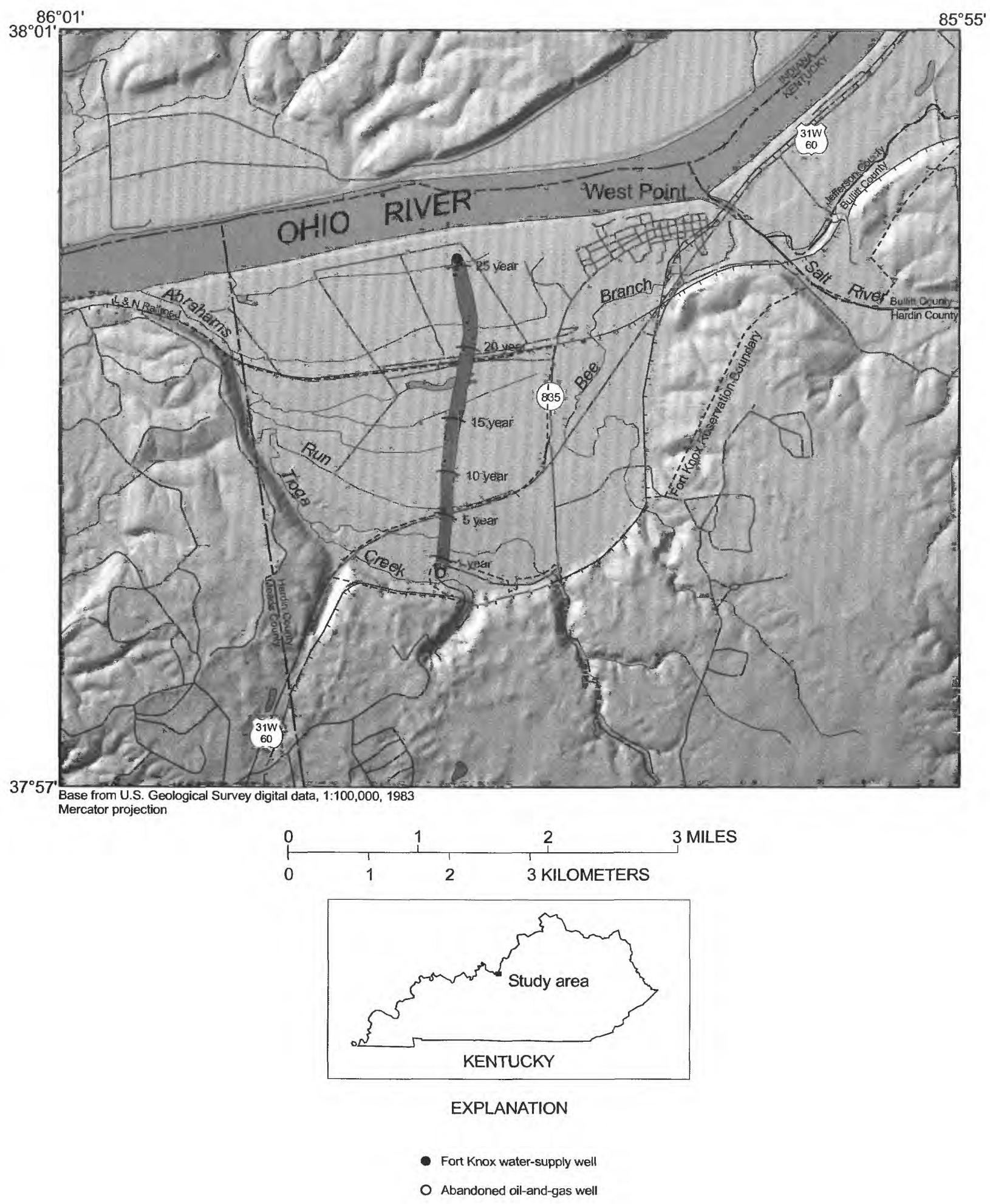

Figure 34. Flow paths and time-of-travel estimates from particle-tracking application of flow from an imaginary abandoned oil-and-gas well. 


\section{SUMMARY}

The alluvial aquifer near West Point, Ky., consists of glacial-outwash deposits of Pleistocene and Recent age underlain by shales of Early-Mississippian and Late-Devonian age and limestones of Devonian age. The glacial outwash is composed of medium- to coarsegrained sand with lenses of gravel intermixed and capped by a thick layer of fine-grained sand, silt, and clay. The direction of ground-water flow in the sand and gravel deposits is predominantly from the bedrock valley walls toward the Ohio River and ground-water withdrawal wells.

The presence of a gas-storage field is a unique feature of the study area. Natural gas is stored in the limestones beneath the shales and alluvium; excess gas is stored during periods of low demand and removed from storage as the demands increase. The limestone formations provide more than 2 billion $\mathrm{ft}^{3}$ of storage. The effect from the pressurization of the field on the water levels, ground-water flow, and water quality of the ground water is unknown at this time. Additional monitoring would be necessary to fully assess the effect of this feature.

The alluvial aquifer receives natural recharge from several sources-direct infiltration of precipitation, subsurface flow from the consolidated rocks, and flow from the Ohio River to the aquifer when the stage of the river is higher than the adjacent ground-water levels. Additional recharge to the alluvial aquifer occurs as the pumping of wells close to the Ohio River induce flow from the river to the aquifer. Discharges from the alluvial aquifer occur by flow to the Ohio River, through pumped wells, and downward flow to the bedrock.

A quasi- three-dimensional, finite-difference model (MODFLOW) of the alluvial aquifer was calibrated by comparing the simulated hydraulic heads with corresponding measured water levels in 32 area wells during assumed steady-state conditions in November 1997. The model simulation indicates ground water enters the system primarily from precipitation infiltration ( 50 percent), flow from the bedrock valley walls (49 percent), and induced infiltration of water from the Ohio River ( 1 percent). The water exits the system by ground-water pumpage ( 29 percent), flow to the Ohio River (68 percent), and flow to the bedrock ( 3 percent). A sensitivity analysis of the input parameters indicated the model simulation is most sensitive to changes in (1) general head-boundary conductance, (2) natural recharge (precipitation), and (3) hydraulic conductivity of the alluvial aquifer.

Results of simulations made with the calibrated ground-water-flow model were applied in an advectiveflow particle-tracking program. The MODPATH code was used to delineate ground-water flow paths, and contributing areas to supply wells, and to estimate travel times of water through the aquifer from recharge points to discharge points (wells) or boundaries (the Ohio River). 


\section{REFERENCES CITED}

Bell, E.A., 1966, Summary of hydrologic conditions of the Louisville area, Kentucky: U.S. Geological Survey Water-Supply Paper 1819-C, 36 p.

Brabets, T.P., 1995, Application of surface geophysical techniques in a study of the geomorphology of the lower Copper River, Alaska: U.S. Geological Survey Water-Resources Investigations Report 94-4165, $47 \mathrm{p}$.

Brown, R.I., and Lambert, T.W., 1963, Availability of ground water in Breckinridge, Grayson, Hardin, Larue, and Meade Counties, Kentucky: U.S. Geological Survey Hydrologic Investigations Atlas HA-33, 3 sheets, scale 1:250,000.

Buschbach, T.C., and Bond, D.C., 1967, Underground storage of natural gas in Illinois-1967: Illinois State Geological Survey, Illinois Petroleum 86, $54 \mathrm{p}$.

Dumouchelle, D.H., Schalk, C.W., Rowe, G.L., and deRoche, J.T., 1993, Hydrogeology, simulated ground-water flow, and ground-water quality, Wright-Patterson Air Force Base, Ohio: U.S. Geological Survey Water-Resources Investigations Report 93-4047, 152 p.

Freeze, R.A., and Cherry, J.A., 1979, Groundwater: Englewood Cliff, N.J., Prentice-Hall, 604 p.

Gallaher, J.T., 1964, Geology and hydrology of alluvial deposits along the Ohio River between the Wolf Creek and West Point areas, Kentucky: U.S. Geological Survey Hydrologic In vestigations Atlas HA-95, 1 sheet, scale 1:250,000.

Gallaher, J.T., and Price, W.E., Jr., 1966, Hydrology of the alluvial deposits in the Ohio River Valley in Kentucky: U.S. Geological Survey Water-Supply Paper 1818, 80 p.

Grubb, H.F., and Zehner, H.H., 1973, Aquifer diffusivity of the Ohio River alluvial aquifer by the floodwave response method: U.S. Geological Survey Journal Research, v. 1, no. 5, SeptemberOctober 1973, p. 597-601.

Hanei, F.P., 1986, Application of continuous seismic reflection methods to hydrologic studies: Ground Water, v. 24 , no. 1 , p. 23-31.

Hvorslev, M.J., 1951, Time lag and soil permeability in groundwater observations: U.S. Army Corps of Engineers Waterways Experiment Station Bulletin 36, Vicksburg, Miss.

Kepferle, R.C., and Sable, E.G., 1977, Geologic map of the Fort Knox quadrangle, north-central Kentucky: U.S. Geological Survey Geologic Quadrangle Map GQ-1375, scale 1:24,000.
Lyverse, M.A., and Unthank, M.D., 1988, Assessment of ground-water contamination in the alluvial aquifer near West Point, Kentucky: U.S. Geological Survey Water-Resources Investigations Report 88-4166, 25 p.

McDonald, M.G., and Harbaugh, A.W., 1988, A modular three-dimensional finite-difference ground-water flow model: U.S. Geological Survey Techniques of Water-Resources Investigations, book 6, chap. A1, 528 p.

Pollock, D.W., 1989, Documentation of computer programs to compute and display pathlines using results from the U.S. Geological Survey modular three-dimensional finite-difference ground-waterflow model: U.S. Geological Survey Open-File Report 89-381, 188 p.

1994, User's guide for MODPATH/MODPATHPLOT, version 3-A particle-tracking postprocessing package for MODFLOW, the U.S. Geological Survey finite-difference groundwater-flow model: U.S. Geological Survey OpenFile Report 94-464, 249 p.

Robinson, J.L., Carmichael, J.K., Halford, K.J., and Ladd, D.E., 1997, Hydrogeologic framework and simulation of ground-water flow and travel time in the shallow aquifer system in the area of naval support activity, Memphis, Millington, Tennessee: U.S. Geological Survey Water-Resources Investigations Report 97-4228, $56 \mathrm{p}$.

Rorabaugh, M.I., 1956, Ground water in northeastern Louisville, Kentucky, with reference to induced infiltration: U.S. Geological Survey Water-Supply Paper 1360-B, 169 p.

Smith, H.F., 1971, Subsurface storage and disposal in Illinois: Ground Water, v. 9, no. 6, NovemberDecember 1971 , p. 20-28.

Walker, E.H., 1957, The deep channel and alluvial deposits of the Ohio Valley in Kentucky: U.S. Geological Survey Water-Supply Paper 1411, 25 p., 6 pls. 